\title{
THE
}

\section{Trophic position and foraging ecology of Ross, Weddell, and crabeater seals revealed by compound-specific isotope analysis}

\author{
Emily K. Brault \\ Paul L. Koch \\ Daniel P. Costa \\ Matthew D. McCarthy \\ Luis A. Hückstädt
}

See next page for additional authors

Follow this and additional works at: https://digitalcommons.uri.edu/gsofacpubs This is a pre-publication author manuscript of the final, published article. Creative Commons License

\section{(c) (†)}

This work is licensed under a Creative Commons Attribution 4.0 License.

\section{Citation/Publisher Attribution}

Brault EK, Koch PL, Costa DP, McCarthy MD and others (2019) Trophic position and foraging ecology of Ross, Weddell, and crabeater seals revealed by compound-specific isotope analysis. Mar Ecol Prog Ser 611:1-18. https://doi.org/10.3354/meps12856

Available at: https://doi.org/10.3354/meps12856

This Article is brought to you for free and open access by the Graduate School of Oceanography at DigitalCommons@URI. It has been accepted for inclusion in Graduate School of Oceanography Faculty Publications by an authorized administrator of DigitalCommons@URI. For more information, please contact digitalcommons-group@uri.edu. 


\section{Authors}

Emily K. Brault, Paul L. Koch, Daniel P. Costa, Matthew D. McCarthy, Luis A. Hückstädt, Kimberly Goetz, Kelton W. McMahon, Michael G. Goebel, Olle Karlsson, Jonas Teilmann, Tero Härkönen, and Karin Hårding 
1 TROPHIC POSITION AND FORAGING ECOLOGY OF ROSS, WEDDELL, AND

2 CRABEATER SEALS REVEALED BY COMPOUND-SPECIFIC ISOTOPE ANALYSIS

4 Emily K. Brault ${ }^{1}$, Paul L. Koch ${ }^{2}$, Daniel P. Costa $^{3}$, Matthew D. McCarthy ${ }^{1}$, Luis A. Hückstädt ${ }^{3}$,

5 Kimberly Goetz ${ }^{4}$, Kelton W. McMahon ${ }^{5}$, Michael E. Goebel ${ }^{6}$, Olle Karlsson ${ }^{7}$, Jonas Teilmann ${ }^{8}$,

6 Tero Härkönen ${ }^{7}$, and Karin Hårding ${ }^{9}$

$8{ }^{1}$ Ocean Sciences Department, University of California, Santa Cruz, 1156 High Street, Santa

9 Cruz, CA 95064, USA, ebrault@ucsc.edu

$10{ }^{2}$ Earth and Planetary Sciences Department, University of California, Santa Cruz, 1156 High

11 Street, Santa Cruz, CA 95064, USA

$12{ }^{3}$ Ecology and Evolutionary Biology, University of California, Santa Cruz, 100 Shaffer Road,

13 Santa Cruz, CA 95064, USA

$14{ }^{4}$ National Institute of Water and Atmospheric Research, 301 Evans Bay Parade, Wellington

156021 , New Zealand

$16{ }^{5}$ Graduate School of Oceanography, University of Rhode Island, 215 S Ferry Rd, Narragansett,

17 RI 02882

$18{ }^{6}$ Antarctic Ecosystem Research Division, NOAA Fisheries, Southwest Fisheries Science Center,

198901 La Jolla Shores Dr., La Jolla, CA 92037, USA

$20{ }^{7}$ Swedish Museum of Natural History, Box 50007, 10405 Stockholm Stockholm, Sweden

$21{ }^{8}$ Department of Bioscience - Marine Mammal Research, Aarhus University, Frederiksborgvej

22 399, Building 7425, P1.26, 4000 Roskilde, Denmark

$23{ }^{9}$ Department of Biological and Environmental Sciences, University of Gothenburg, Box 463, 
24 SE-405 30 Gothenburg, Sweden

$25 *$ Corresponding author

\section{ABSTRACT}

Ross seals (Ommatophoca rossii) are one of the least studied marine mammals, with little known about their foraging ecology. Research to date using bulk stable isotope analysis suggests

31 that Ross seals have a trophic position intermediate between that of the Weddell (Leptonychotes

32 weddellii) and crabeater (Lobodon carcinophaga) seals. However, consumer bulk isotope values

33 not only reflect trophic dynamics, but also variations in baseline isotope values, which can be

34 substantial. Here, we use a compound specific isotope analysis of amino acids (CSI-AA) to

35 separate isotopic effects of a shifting baseline versus trophic structure on the foraging ecology of

36 these ecologically important, but poorly understood Antarctic pinnipeds. We find that all three

37 seals use different foraging habitats; Ross seals forage in a pelagic food web distinct from that of

38 crabeater and Weddell seals. Crabeater and Weddell seals are foraging within similar food webs

39 closer to shore. However, isotopic evidence suggests that crabeater seals are likely following sea

40 ice, while Weddell seals target productive areas of the continental shelf of Western Antarctica. In

41 addition, our CSI-AA data indicate that Ross seals have a high trophic position equivalent to that

42 of Weddell seals, contrary to prior conclusions from nitrogen isotope results on bulk tissues.

43 CSI-AA indicates that crabeater seals are at a trophic position lower than that of Ross and

44 Weddell seals, consistent with a krill-dominated diet. Our results redefine the view of the Ross

45 seal trophic dynamics and foraging ecology, while also highlighting the importance of

46 quantifying baseline isotope variations in foraging studies. 


\section{KEYWORDS}

50 Ross seal, Weddell seal, Crabeater seal, Compound specific isotopes, amino acids, Antarctica, 51 Foraging ecology, Trophic dynamics

\section{INTRODUCTION}

The Ross seal (Ommatophoca rossii) is one of the least studied marine mammals (Reeves

et al. 2008, Bengtson et al. 2011). The total population estimate for this species is around 200,000, considerably less than the estimates for other Antarctic true seals, which are 10 to 15

57 million individuals for crabeater seals (Lobodon carcinophaga) and approximately one million

58 individuals for Weddell seals (Leptonychotes weddellii) (Laws 1977, Reeves et al. 2008,

59 Bengtson et al. 2011). With individuals likely spending most of their time at sea and in habitats

60 that are logistically challenging to access, the Ross seal is not commonly observed. Several keys

61 aspects of their biology remain poorly understood, including their preferred prey, foraging

62 habitat, and behavior. In contrast, many studies have been conducted on crabeater and Weddell

63 seals and, thus, more information is available on their ecology.

64 Conventional techniques for studying an animal's diet, such as scat and stomach content 65 analysis, have significant limitations when applied to Antarctic pinnipeds. These methods 66 capture only a snapshot of a predator's diet, perhaps one to two days (Dellinger and Trillmich 67 1988, Burns et al. 1998). In addition, since soft tissues are more completely digested than hard 68 tissues, resulting in biases towards prey with indigestible hard parts (Burns et al. 1998, Staniland 
2002, Arim and Naya 2003, Yonezaki et al. 2003). Given these drawbacks, recent research on Antarctic seal ecology has often used bulk isotope values.

Measurements of bulk tissue carbon $\left(\delta^{13} \mathrm{C}\right)$ and nitrogen $\left(\delta^{15} \mathrm{~N}\right)$ isotope values (i.e., the weighted average of all components within in a tissue) have been used to indicate a predator's foraging region and trophic position (Boecklen et al. 2011). This approach has the advantage of

providing an integrated view of an animal's diet over longer time scales (weeks to years depending on the tissue) than the traditional procedures (Vander Zanden et al. 2015). Carbon isotope values show little ${ }^{13} \mathrm{C}$-enrichment with trophic transfer. Thus, consumer $\delta^{13} \mathrm{C}$ values are often thought to closely reflect values at the base of marine food webs, making them useful for studying the foraging areas of a predator. Spatial changes in the $\delta^{13} \mathrm{C}$ of phytoplankton (often referred to as "baseline" $\delta^{13} \mathrm{C}$ values) reflect variations in dissolved inorganic carbon $\delta^{13} \mathrm{C}$ values, dissolved $\mathrm{CO}_{2}$ concentrations, temperature, cell size and geometry, internal biological parameters (e.g., growth rate), and $\mathrm{CO}_{2}$ drawdown (reviewed in McMahon et al. 2013). Provided the primary processes driving variation are known, bulk $\delta^{13} \mathrm{C}$ values of an animal can give valuable information on its foraging habitat. The Southern Ocean is known to have considerable spatial variation in baseline $\delta^{13} \mathrm{C}\left(\delta^{13} \mathrm{C}_{\text {baseline }}\right)$ values (Rau et al. 1982, Quillfeldt et al. 2010, Brault et al. 2018). Several studies have observed decreasing $\delta^{13} \mathrm{C}$ values with increasing latitude, with offsets between about $55^{\circ} \mathrm{S}$ and $79^{\circ} \mathrm{S}$ of approximately $3 \%$, largely reflecting variations in sea surface temperature (Rau et al. 1982, Graham et al. 2010, Quillfeldt et al. 2010, Magozzi et al. 2017, Brault et al. 2018).

In contrast to carbon isotopes, trophic transfers considerably affect an animal's $\delta^{15} \mathrm{~N}$ values. Since a consumer's tissues become enriched in ${ }^{15} \mathrm{~N}$ by $\sim 2-5 \%$ with each trophic step (e.g., primary producers to herbivores to carnivores) due to the preferential loss of ${ }^{14} \mathrm{~N}$ during 
92 amino acid metabolism (Minagawa and Wada, 1984), $\delta^{15} \mathrm{~N}$ values are often used to indicate an

93 animal's trophic position. However, variations in baseline $\delta^{15} \mathrm{~N}$ values $\left(\delta^{15} \mathrm{~N}_{\text {baseline }}\right)$ also occur

94 and are passed on, with additional change due to trophic transfers, to upper trophic level

95 predators (McMahon et al. 2013). Nutrient source (e.g., nitrate, ammonium, or $\mathrm{N}_{2}$ fixation),

96 microbial transformations (e.g., denitrification), and extent of nitrogen pool drawdown in a given

97 environment can all strongly impact primary producer $\delta^{15} \mathrm{~N}$ values (reviewed in McMahon et al.

98 2013). If variations in these factors are well understood, then the bulk $\delta^{15} \mathrm{~N}$ values of a consumer

99 provide insights into its foraging region and trophic position (Post 2002). As with carbon,

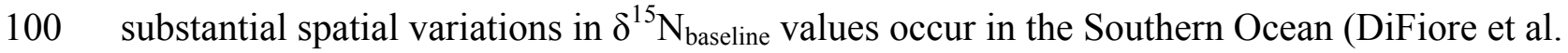

101 2006, DiFiore et al. 2009, Somes et al. 2010, Jaeger et al. 2010, Brault et al. 2018). Low

$102 \delta^{15} \mathrm{~N}_{\text {baseline }}$ values have been found for much of the Southern Ocean except in areas near the

103 continent with extensive coastal open water polynya "hot spots" (Arrigo and Van Dijken 2003),

104 where the baseline is up to $\sim 3 \%$ higher than in pelagic regions (DiFiore et al. 2006, DiFiore et

105 al. 2009, Brault et al. 2018). This pattern likely derives from changes in the extent of nutrient

106 drawdown due to enhanced primary productivity, the main process influencing $\delta^{15} \mathrm{~N}_{\text {baseline }}$ in the

107 Southern Ocean since it is a high nutrient-low chlorophyll (HNLC) region (Brault et al. 2018).

108 Although much remains unknown, especially regarding the behaviors and movements of

109 the Ross seal, recent studies have furthered our understanding of Antarctic seal ecology. Isotopic

110 measurements, coupled with traditional ecological methods, have indicated that Weddell seals

111 forage near the top of the Antarctic food web, consuming diverse diets of fish, cephalopods, and

112 invertebrates (Burns et al. 1998, Plötz 2001, Lake et al. 2003, Goetz et al. 2017). Researchers

113 have debated the contribution of the upper trophic level prey species, in particular the Antarctic

114 toothfish (Dissotichus mawsoni), to Weddell seal diets with some studies suggesting a substantial 
115 contribution of D. mawsoni (Ponganis and Stockard 2007, Ainley and Siniff 2009, Goetz et al.

116 2017). Hard parts of D. mawsoni are not consumed and, thus, not detected via scat and stomach

117 content analyses, which have been used for much of the prior research on Weddell seal foraging

118 ecology. Recently, Goetz et al. (2017) assessed Weddell seal foraging ecology with bulk $\delta^{13} \mathrm{C}$

119 and $\delta^{15} \mathrm{~N}$ measurements of vibrissae and red blood cells from Ross Sea specimens. They reported

120 considerable individual variability in diet and that Antarctic silverfish (Pleuragamma

121 antarcticum) and cod icefishes (Trematomus species) were the primary prey consumed by

122 Weddell seals. Overall, D. mawsoni contribute less than $2 \%$ to the Weddell seal diet. However,

123 D. mawsoni may become increasingly important with age and at certain times in the life cycle,

124 such as during reproduction and molting, since this fish has a high fat content and energy density

125 (Goetz et al. 2017). Additionally, Goetz et al. (2017) noted temporal diet shifts - likely in

126 response to sea ice dynamics affecting prey abundances.

127 Crabeater seals occupy a much lower trophic level than Weddell seals, with diets

128 dominated by Antarctic krill (Euphausiia superba), as evidenced by the results of both scat and

129 stomach content analyses as well as bulk isotopic analysis (Laws 1977, Rau et al. 1992, Burns et

130 al. 2004, Zhao et al. 2004, Burns et al. 2008, Aubail et al. 2011). Recent work by Hückstädt et al.

131 (2012a) has revealed temporal variability in crabeater seal diet composition via bulk $\delta^{13} \mathrm{C}$ and

$132 \delta^{15} \mathrm{~N}$ measurements of vibrissae. The E. superba contribution ranged from $81 \%$ to $95 \%$, likely

133 in response to climate shifts affecting krill abundances. The authors also reported significant

134 variation in $\delta^{13} \mathrm{C}$ values with body mass (increasing $\delta^{13} \mathrm{C}$ values with increasing body mass) and 135 season (highest $\delta^{13} \mathrm{C}$ values in the austral winter) that they suggested might result from changes

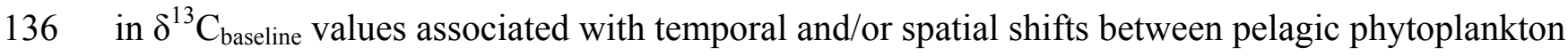
137 and sea ice phytoplankton communities (Hückstädt et al. 2012a). 
Only a small number of studies have examined Ross seal foraging ecology. Dive records suggest that these animals typically dive from 100 to $300 \mathrm{~m}$ (maximum depth of $792 \mathrm{~m}$ ) in search of mesopelagic squid and fish (Bengtson and Stewart 1997, Blix and Nordøy 2007).

141 Analysis of Ross seal stomach contents showed that Antarctic silverfish (Pleurogramma 142 antarcticum) and glacial squid (Psychroteuthis glacialis) were found in varying proportions

143 (Skinner and Klages, 1994). Arcalís-Planas et al. (2015) suggested little use of sea ice by Ross

144 seals, based on telemetry and remote sensing data. Seals tracked in this study generally

145 remained in pelagic regions except for haul outs on ice to molt (from December to January) and 146 breed (from late October to mid-November). During their extended pelagic period (February to 147 mid-October), Ross seals remained an average $\sim 840 \mathrm{~km}$ (range 587 to 1,282 km) seaward from 148 the ice edge (Arcalís-Planas et al. 2015). Bulk $\delta^{13} \mathrm{C}$ and $\delta^{15} \mathrm{~N}$ isotope measurements place the 149 Ross seal a trophic level intermediate between Weddell seals and crabeater seals (Rau et al. 150 1992, Zhao et al. 2004, Aubail et al. 2011). Thus, bulk isotope results to date suggest that Ross 151 seals consume mostly squid and fish, but with a contribution from lower trophic level prey like 152 E. superba (Rau et al. 1992, Zhao et al. 2004, Aubail et al. 2011).

153 While these bulk isotope approaches have shed new light on the foraging ecology of 154 these Antarctic pinnipeds, it is critical to remember that the Southern Ocean exhibits strong

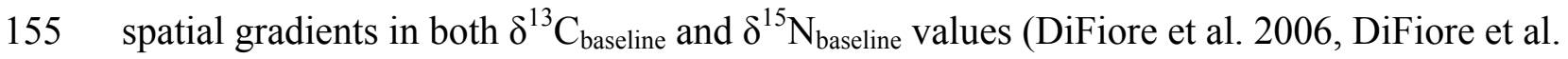
1562009 , Jaeger et al. 2010, Somes et al. 2010, Brault et al. 2018), suggesting that we likely need to 157 explicitly tease apart the relative influences of trophic dynamics and baseline variation on seal 158 isotope values. For instance, Ross seals may spend more time in pelagic regions than other true 159 Antarctic seals (Arcalís-Planas et al. 2015), and thus forage in areas with lower $\delta^{15} \mathrm{~N}_{\text {baseline values }}$ 160 than the nearshore regions of Weddell and crabeater seals (DiFiore et al. 2006, DiFiore et al. 
1612009 , Brault et al. 2018). If so, not accounting for spatial variation in the $\delta^{15} \mathrm{~N}_{\text {baseline would result }}$

162 in Ross seals being assigned a lower trophic position than species foraging nearer the continent.

163 Compound-specific isotopic analysis of amino acids (CSI-AA) has opened new doors to

164 studying the foraging ecology and trophic dynamics of marine predators (e.g., Graham et al.

165 2010). Since only certain amino acids become enriched in ${ }^{15} \mathrm{~N}$ with increasing trophic level

166 ("trophic" amino acids), while others ("source" amino acids) do not, impacts of $\delta^{15} \mathrm{~N}_{\text {baseline }}$

167 variation and trophic position on consumer $\delta^{15} \mathrm{~N}$ values can be disentangled using this technique

168 (Ohkouchi et al. 2017). Glutamic acid/glutamine (Glu) and phenylalanine (Phe) are widely

169 considered the most representative trophic and source amino acids, respectively, with Phe $\delta^{15} \mathrm{~N}$

170 values typically used a proxy for baseline isotope values, and Phe and Glu $\delta^{15} \mathrm{~N}$ values $\left(\delta^{15} \mathrm{~N}_{\text {Phe }}\right.$

171 and $\delta^{15} \mathrm{~N}_{\mathrm{Glu}}$, correspondingly) used together to estimate an organism's trophic position (TP)

172 internally indexed to the baseline (Ohkouchi et al. 2017). Proline (Pro) has also been shown to be

173 a reliable trophic amino acid, however, with less variability than Glu for trophic ${ }^{15} \mathrm{~N}$-enrichment

174 factors between organisms (McMahon et al. 2015). As a consequence, Pro and Phe may

175 represent a new CSI-AA combination that provides more ecologically realistic TP estimates for

176 higher trophic level consumers (McMahon and McCarthy 2016).

177 Here, we report the first CSI-AA data for modern Ross, Weddell, and crabeater seals to

178 refine our understanding of the trophic dynamics and foraging ecology of these important

179 Antarctic predators. In particular, CSI-AA allows us to directly examine changes in baseline

$180 \delta^{15} \mathrm{~N}$ values linked to these seals' diets, and so to gain information on their foraging regions in

181 conjunction with their trophic dynamics. Comparison of amino acid isotope data across these

182 three Antarctic seals will also further our understanding of present Antarctic food web structures, 
183 which will provide valuable ecosystem baselines in light of ongoing climate change (Atkinson et

184 al. 2004, Ducklow et al. 2007, Ducklow et al. 2012, Montes-Hugo et al. 2009).

\section{MATERIALS AND METHODS}

\section{Sample collection}

Tissue samples from Ross $(n=15)$, Weddell $(n=38)$, and crabeater seals $(n=41)$ were collected along western Antarctica from the West Antarctic Peninsula (WAP) to the Ross Sea

190 during multiple field seasons in the austral summers of 2008/09 and 2010/11 aboard the $R V$

191 Oden. These animal captures were conducted in accordance with the regulations of the Swedish

192 Polar Research Secretariat (Registration No. 2010-112). All other samples were obtained from

193 animal captures conducted under National Marine Fisheries Service permit No. 87-1851-00. In

194 most cases, body mass, age class (juvenile, subadult, and adult), gender, and location were

195 recorded for each sampled seal (Table S1). Additionally, the Institutional Animal Care and Use

196 Committee (IACUC) at the University of Santa Cruz (UC Santa Cruz) approved all protocols for 197 these samples.

198 Whole blood samples were obtained from most seals, and in some cases, clot (blood with

199 serum removed), red blood cells (RBCs, whole blood exposed to an anticoagulant, heparin,

200 before having plasma removed), and hair samples were also collected. The sampling protocols

201 are described in Aubail et al. (2011) and Goetz et al. (2017). Whiskers were taken from crabeater

202 seals during multiple cruises on the $R V$ Lawrence M. Gould along the WAP, during fall 2001 (n $203=7)$, winter $2001(n=7)$, fall $2002(n=15)$, winter $2002(n=14)$, and fall $2007(n=9)$. Plasma

204 was also obtained from a few of the fall 2007 individuals (G105, G110, and G112) (Hückstädt et 205 al. 2012a). In addition, serum or plasma was obtained from two Weddell seals during the fall 
2007 sampling in this region, and whiskers were taken from two WAP Weddell seals in the

207 austral summer of 2009/10. Whisker samples were also collected from Weddell seals during the

208 summer 2009/10 ( $n=11)$, summer 2010/11 $(n=10)$, summer 2011/12 ( $n=18)$ (Goetz et al. 2017).

209 Hückstädt et al. (2012a) describe the procedure for sampling the whiskers, and Goetz et al.

210 (2017) describe the protocol used for collecting seal blood.

211 Several blood samples were obtained from Weddell seals in the McMurdo Sound region,

212 Ross Sea, Antarctica over multiple field seasons. Twelve whole blood samples were taken from

213 juvenile Weddell seals near Inexpressible Island $\left(74.9^{\circ} \mathrm{S}, 163.7^{\circ} \mathrm{E}\right)$ during the austral summer of

214 2010/11. Whole blood samples were taken from Weddell seals in the austral summer of 2010/11

$215(n=5)$ and austral spring of $2012(n=5)$. RBCs were sampled in the austral summer of 2009/10

$216(n=5)$, austral summer of 2011/12 $(n=5)$, and austral spring of $2012(n=5)$. Whole blood, plasma,

217 and serum were obtained from five Weddell seals sampled in the austral spring of 2015, and

218 whole blood from an additional seven Weddell seals was also acquired during this time. Goetz et

219 al. (2017) describe the sampling protocol for these Weddell seals.

220 Lastly, a few samples were obtained from crabeater seals in McMurdo Sound. Hair

221 samples were taken from three recently deceased juvenile crabeater seals that were found on the

222 seasonal pack ice around Cape Royds in the austral summer of 2009/10. Whole blood was

223 sampled, using the protocol of Goetz et al. (2017), from a male adult crabeater seal found in

224 Erebus Bay during the austral summer of 2010/11.

225

\section{Sample preparation}

227 After sample collection, all samples were kept frozen at $-20{ }^{\circ} \mathrm{C}$. Blood samples were 228 freeze-dried with a Labconco Freeze Dry System (Lyph Lock 4.5) and homogenized manually 
229 prior to isotope analysis. Lipid extraction was not performed on the blood samples, as blood has

230 a relatively low lipid content. A test set of blood samples with and without lipid extraction

231 revealed no significant effect of lipid extraction on blood $\delta^{13} \mathrm{C}$ values (Table S2), though lipid

232 extraction did have an undesired impact on $\delta^{15} \mathrm{~N}$ values (Table S2).

233 Hair and whisker samples are known to have high enough lipid contents to affect $\delta^{13} \mathrm{C}$

234 values so these samples were lipid extracted a la Hückstädt et al. (2012a). These samples were

235 washed with Milli-Q water (Thermo Fisher Scientific, Inc.) and then rinsed three times in an

236 ultrasonic bath with petroleum ether for 15 minutes.

\section{Bulk stable isotope analysis}

For all blood and hair samples, $\sim 1 \mathrm{mg}$ was weighed into tin cups (Costech, $3 \times 5 \mathrm{~mm}$ ) for

240 bulk stable carbon and nitrogen isotope analysis. For hair, the follicle was removed since prior

241 work has shown it to have a different biochemical and isotopic composition than the rest of the

242 hair (Hückstädt et al. 2012b). This analysis was performed at the Stable Isotope Lab (SIL) of

243 University of California - Santa Cruz (UCSC) on a Carlo Erba EA 1108 elemental analyzer

244 coupled to a Thermo-Finnigan Delta ${ }^{\text {Plus }} \mathrm{XP}$ isotope ratio mass spectrometer. The $\delta^{13} \mathrm{C}$ values

245 were referenced to the V-PDB standard, and $\delta^{15} \mathrm{~N}$ values were referenced to AIR. PUGel and

246 Acetanilide standards were analyzed in each instrument session in order to correct for variations

247 in mass across samples and instrument drift. Across 10 analytical sessions, the standard

248 deviations were $0.1 \%(n=139)$ for $\delta^{13} \mathrm{C}, 0.1 \%(\mathrm{n}=139)$ for $\delta^{15} \mathrm{~N}$, and $0.1(\mathrm{n}=139)$ for $\mathrm{C} / \mathrm{N}$

249 (atomic) for PUGel and $0.2 \%(n=38)$ for $\delta^{13} \mathrm{C}, 0.2 \%$ o $(\mathrm{n}=38)$ for $\delta^{15} \mathrm{~N}$, and $0.4(\mathrm{n}=38)$ for

$250 \mathrm{C} / \mathrm{N}$ (atomic) for Acetanilide. 


\section{Compound-specific isotope analysis}

CSI-AA was performed at UCSC via gas chromatography-combustion-isotope ratio mass

254 spectrometry (GC-C-IRMS). All samples were prepared for GC-C-IRMS analysis using the

255 methods described in McCarthy et al. (2007) and McCarthy et al. (2013). In brief, samples were

256 hydrolyzed $\left(6 \mathrm{~N} \mathrm{HCl}\right.$ for $20 \mathrm{hr}$ at $\left.110^{\circ} \mathrm{C}\right)$ and converted to trifluoro-acetylated isopropyl amino

257 acid derivatives. Samples were stored at $-20^{\circ} \mathrm{C}$ in a 1:3 TFAA:DCM (dichloromethene) solution

258 until analysis. Immediately before the analysis, the TFAA/DCM mixture was evaporated under

$259 \mathrm{~N}_{2}$ and samples were diluted in ethyl acetate.

260 Amino acid $\delta^{15} \mathrm{~N}$ values were measured on a Thermo Trace GC coupled to a Thermo-

261 Finnigan Delta ${ }^{\text {Plus }}$ XP isotope-ratio-monitoring mass spectrometer (oxidation furnace at $980{ }^{\circ} \mathrm{C}$

262 and reduction furnace at $650^{\circ} \mathrm{C}$ ) using an SGE Analytical Science BPX5 column (60 m by 0.32

$263 \mathrm{~mm}$ with a $1 \mu \mathrm{m}$ film thickness). The injector temperature was $250{ }^{\circ} \mathrm{C}$ with a split He flow of 2

$264 \mathrm{~mL} / \mathrm{min}$. The GC temperature program was: initial temp $=70^{\circ} \mathrm{C}$ hold for $1 \mathrm{~min}$; $\operatorname{ramp} 1=10^{\circ} \mathrm{C}$

$265 / \min$ to $185^{\circ} \mathrm{C}$, hold for $2 \mathrm{~min}$; ramp $2=2{ }^{\circ} \mathrm{C} / \mathrm{min}$ to $200{ }^{\circ} \mathrm{C}$, hold for $10 \mathrm{~min}$; ramp $3=30$

$266{ }^{\circ} \mathrm{C} / \mathrm{min}$ to $300{ }^{\circ} \mathrm{C}$, hold for $6 \mathrm{~min}$. Directly measured amino acid $\delta^{15} \mathrm{~N}$ values were corrected

267 based on bracketed external standards of amino acids with known isotopic composition, as

268 described in McCarthy et al. (2013). The $\delta^{15} \mathrm{~N}$ values of 11 amino acids were quantified: alanine

269 (Ala), glycine (Gly), threonine (Thr), serine (Ser), valine (Val), leucine (Leu), Pro, aspartic acid

270 + asparagine (Asp), Glu, Phe, and lysine (Lys).

271

272 Data analysis

273 Most samples were whole blood. Since bulk isotope values can vary across different

274 tissues, species-specific corrections were applied to account for isotopic offsets between different 
275 types of samples (see methods in Supplementary Material and resulting correction factors in

276 Tables S3-S6). These corrections were applied to all bulk isotope data from tissues other than

277 whole blood that had significant isotopic offsets from whole blood. An isotopic offset $>0.2 \%$ o

278 was considered significant, since the instrument error is $\leq 0.2 \%$.

All data analyses were performed in R statistical software (R Core Team, 2014). Tests of

280 normality and equal variance were conducted to assure test assumptions were met. In a few

281 cases, an assumption was violated and a data transformation was applied, as noted in Results.

282 Bulk isotope values of the three different seal species were compared with a one-way analysis of

283 variance (ANOVA) and post-hoc Bonferroni pairwise comparisons. Data were Box-Cox

284 transformed (Box and Cox, 1964). A four-way ANOVA with post-hoc Bonferroni pairwise

285 comparisons was used to test for significant effects of gender, sampling period, age class, and

286 region (WAP, Amundsen Sea, and Ross Sea) on the bulk isotopic values of Ross, Weddell, and

287 crabeater seals. Both Weddell and crabeater seal data were Box-Cox transformed. Linear

288 regression analyses were used to test for significant relationships between bulk $\delta^{13} \mathrm{C}$ and $\delta^{15} \mathrm{~N}$

289 values and body mass for each species.

290 A one-way ANOVA with post-hoc Bonferroni pairwise comparisons was used to test for

291 significant differences in the $\delta^{15} \mathrm{~N}$ values of each amino acid among the three seal species. This

292 same procedure was conducted to compare the $\delta^{15} \mathrm{~N}$ values for each category of amino acid (i.e.,

293 source or trophic) among the different seal species. For both Weddell and crabeater seals, a two-

294 tailed student's $t$-test was used to compare the $\delta^{15} \mathrm{~N}$ values of Pro, Glu and Phe for the WAP to

295 those of a combined Amundsen and Ross Sea region (“Amundsen/Ross Sea” in the subsequent

296 text). Amino acid $\delta^{15} \mathrm{~N}$ values for seals from the Amundsen/Ross Seas were combined by species

297 (crabeater or Weddell) since both species had bulk $\delta^{15} \mathrm{~N}$ values that were similar between these 
two regions. This analysis was not done for Ross seals since this species was almost exclusively sampled in the Amundsen Sea. A two-tailed student's $t$-test was used to compare the $\delta^{15} \mathrm{~N}_{\text {Phe }}$

300 values of Weddell seals to those of crabeater seals for the WAP, and a one-way ANOVA with

301 post-hoc Bonferroni pairwise comparisons was conducted to assess variation between the $\delta^{15} \mathrm{~N}_{\text {Phe }}$

302 values of Ross, Weddell, and crabeater seals from the Amundsen/Ross Sea region.

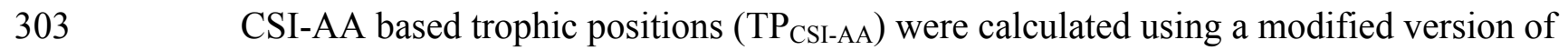

304 the equation originally proposed by Chikaraishi et al. (2009). Here, we substituted Pro for Glu as

305 the trophic amino acid, as suggested by the comparative synthesis of $\mathrm{TP}_{\mathrm{CSI}-\mathrm{AA}}$ methods in

306 McMahon and McCarthy (2016), because Pro trophic discrimination appears to be less variable

307 across variations in diet. McMahon and McCarthy (2016) suggest that this new equation will

308 likely produce more ecologically realistic TP estimates for marine mammals. TP ${ }_{\mathrm{CSI}-\mathrm{AA}}$ was,

309 therefore, calculated as follows:

$$
\mathrm{TP}_{\mathrm{CSI}-\mathrm{AA}}=1+\left[\left(\delta^{15} \mathrm{~N}_{\text {Pro }}-\delta^{15} \mathrm{~N}_{\text {Phe }}-\beta_{\text {Pro/Phe }}\right) / \mathrm{TDF}_{\text {Pro }}\right]
$$

310 where $\delta^{15} \mathrm{~N}_{\text {Pro }}$ is the seal Pro $\delta^{15} \mathrm{~N}$ value, $\beta_{\text {Pro/Phe }}$ is the isotopic difference between Pro and Phe in

311 marine phytoplankton (3.1\%); Chikaraishi et al. 2009), and $\mathrm{TDF}_{\text {Pro }}$ is the trophic discrimination

312 between diet and consumer for Pro minus the same for Phe $\left(\Delta^{15} \mathrm{~N}_{\text {pro }}-\Delta^{15} \mathrm{~N}_{\text {Phe }}=4.5 \%\right.$;

313 McMahon and McCarthy 2016). Differences in TP $\mathrm{CSI}_{-\mathrm{AA}}$ among the three seal species were

314 determined with a one-way ANOVA with post-hoc Bonferroni pairwise comparisons using data

315 for individuals only from the Ross and Amundsen Seas to reduce the effect of location on our

316 findings. Differences in $\mathrm{TP}_{\mathrm{CSI}-\mathrm{AA}}$ between the WAP versus Amundsen and Ross Seas were

317 determined with a two-tailed students $t$-test for Weddell and crabeater seals. For all statistical

318 analyses, a result was considered significant if $p<0.05$. 
Antarctic Seal Foraging Ecology

\section{RESULTS}

\section{Bulk $\delta^{13} \mathbf{C}$ and $\delta^{15} \mathbf{N}$ values of Ross, Weddell, and crabeater seals}

325 Bulk $\delta^{13} \mathrm{C}$ and $\delta^{15} \mathrm{~N}$ values varied significantly among the three species (Fig. 1, Table S7). Ross 326 seals had significantly higher $\delta^{13} \mathrm{C}$ values $(-23.8 \pm 0.3 \%$ for the mean \pm standard deviation, $n=$ 327 15) than both Weddell seals $(-25.0 \pm 0.6 \%, n=125)$ and crabeater seals $(-25.0 \pm 1.4 \%, n=97)$

328 ( $p<0.001$ for post-hoc Bonferroni pairwise comparisons). All seals had $\delta^{15} \mathrm{~N}$ values

329 significantly different from each other: crabeater seal $(7.2 \pm 0.8 \%, n=97)<$ Ross seal $(9.1 \pm 0.4$

$330 \%, n=15)<$ Weddell seal $(12.3 \pm 0.6 \%, n=125)(p<0.001$ for all Bonferroni post-hoc

331 comparisons). We found no consistent relationships between bulk stable isotope values of seals

332 and measures of sampling period, gender, age class, or body mass (see the Supplementary

333 Material).

335 Spatial patterns of bulk $\delta^{\mathbf{1 3}} \mathbf{C}$ and $\delta^{15} \mathbf{N}$ values for Antarctic seals

Both Weddell and crabeater seals showed significant spatial variation in their $\delta^{13} \mathrm{C}$

337 values. Weddell seal $\delta^{13} \mathrm{C}$ values were significantly greater in the Ross Sea $(-25.1 \pm 0.5 \%, n=$ 338 100) and the Amundsen Sea $(-24.7 \pm 0.4 \%, n=21)$ than in the WAP $(-22.9 \pm 0.9 \%, n=4)(p \leq$ 3390.002 in all cases from Bonferroni post-hoc comparisons; Fig. 2a, Table S7). Likewise, the $\delta^{13} \mathrm{C}$ 340 values of crabeater seals along the WAP were significantly higher $(-24.0 \pm 1.1 \%, n=52)$ than 
341 those in the Amundsen Sea $(-26.1 \pm 0.4 \%, n=35)$ and Ross Sea $(-26.1 \pm 0.5 \%$, $n=10)(p<$

3420.001 in both cases for Bonferroni post-hoc comparisons; Fig. 3a, Table S7).

343 Unlike their bulk $\delta^{13} \mathrm{C}$ values, Weddell seals showed no significant differences in bulk

$344 \delta^{15} \mathrm{~N}$ values across the three regions (Fig. 2b, Table S7). In contrast, crabeater seals from the

345 WAP had significantly lower $\delta^{15} \mathrm{~N}$ values $(6.8 \pm 0.6 \%, n=52)$ than those from the Amundsen

346 Sea $(7.6 \pm 0.6 \%, n=35)$ and Ross Sea $(8.0 \pm 1.4 \%, n=10)(p<0.001$ in both cases from

347 Bonferroni post-hoc comparisons, Fig. 3b, Table S7). Note, spatial variation in bulk $\delta^{13} \mathrm{C}$ and

$348 \delta^{15} \mathrm{~N}$ values of Ross seals across West Antarctica could not be examined because all but one of

349 the individuals were from the Amundsen Sea (Fig. S1).

\section{Compound-specific $\boldsymbol{\delta}^{\mathbf{1 5}} \mathbf{N}$ values of Ross, Weddell, and crabeater seals}

Nitrogen isotope values were significantly different among at least two of the three seal

353 species for all amino acids, except Gly (Figs. 4 and S2, Tables S8 and S9). For most trophic

354 amino acids (Glu, Ala, Ile, Leu, Pro, and Val), $\delta^{15} \mathrm{~N}$ values differed significantly among all three

355 species (Table S9), with Weddell $>$ Ross $>$ crabeater. For example, Pro $\delta^{15} \mathrm{~N}$ values of Weddell

356 seals $(20.0 \pm 1.4 \%, n=6)$ are significantly greater than those of Ross $(17.2 \pm 0.5 \%, n=6)$ and

357 crabeater $(15.6 \pm 0.6 \%, n=6)$ seals $(p<0.001$ in both cases from Bonferroni post-hoc

358 comparisons). Pro $\delta^{15} \mathrm{~N}$ values of Ross seals $(17.2 \pm 0.5 \%, n=6)$ are significantly greater than

359 those of crabeater seals $(15.6 \pm 0.6 \%, n=6)$ with a $p$-value of 0.03 from Bonferroni post-hoc

360 comparisons. For the trophic amino acid, Asp, crabeater seals had significantly lower $\delta^{15} \mathrm{~N}$

361 values $(10.1 \pm 0.6 \%, n=6)$ than Weddell $(16.2 \pm 2.2 \%, n=6)$ and Ross seals $(14.1 \pm 1.0 \%$, $n$

$362=6)\left(p<0.001\right.$ in both cases from Bonferroni post-hoc comparisons). Additionally, $\delta^{15} \mathrm{~N}$ values

363 among all trophic amino acids were significantly different among all three seal species $(p<$ 
3640.001 in all cases from Bonferroni post-hoc comparisons) with these values decreasing in the 365 manner: Weddell seals $(21.1 \pm 2.7 \%$ o, $n=42)>$ Ross seals $(17.7 \pm 1.9 \%$ o, $n=41)>$ crabeater 366 seals $(13.5 \pm 1.9 \%, n=42)$. $\delta^{15} \mathrm{~N}$ values were significantly different between at least two seal species for both commonly defined source amino acids (Phe and Lys). For Lys, Ross seals had significantly

369 lower $\delta^{15} \mathrm{~N}$ values $(2.8 \pm 0.7 \%, n=6)$ than Weddell $(5.2 \pm 1.5 \%, n=6)$ and crabeater seals $(5.0$ $370 \pm 0.4 \%, n=6$ ) ( $p$-values of 0.005 and 0.009 , correspondingly, from Bonferroni post-hoc

371 comparisons). Likewise, Ross seals had significantly lower $\delta^{15} \mathrm{~N}_{\text {Phe values }}(2.7 \pm 0.7 \%$ o, $n=6)$

372 than Weddell $(5.7 \pm 0.5 \%, n=6)$ and crabeater seals $(5.2 \pm 1.0 \%, n=6)(p<0.001$ in both 373 cases from Bonferroni post-hoc comparisons). Combined, the $\delta^{15} \mathrm{~N}$ values of these source amino 374 acids (Phe and Lys) for Ross seals $(2.7 \pm 0.7 \%$, $n=11)$ are less than those of crabeater $(5.1 \pm$ $0.7 \%, n=12)$ and Weddell seals $(5.5 \pm 1.1 \%, n=12)$ with $p<0.001$ in all cases from from 376 Bonferroni post-hoc comparisons. While Gly and Ser are challenging to accurately categorize in terms of conventional 378 trophic and source groupings (McMahon and McCarthy 2016), we do note that Ser $\delta^{15} \mathrm{~N}$ values 379 of Weddell seals $(8.7 \pm 1.4 \%, n=6)$ were significantly higher than those of both crabeater $(4.2$ $380 \pm 1.9 \%, n=6)$ and Ross seals $(5.3 \pm 0.6 \%, n=6)(p$-values of $<0.001$ and 0.002 , respectively, 381 from Bonferroni post-hoc comparisons). No significant differences among the three seal species 382 occur for Gly $\delta^{15} \mathrm{~N}$ values. Ross, Weddell, and crabeater seals have Gly $\delta^{15} \mathrm{~N}$ values of $4.9 \pm 1.1$ $383 \%(n=6), 5.4 \pm 2.9 \%$ o $(n=6)$, and $3.8 \pm 2.8 \%$ o $(n=6)$, correspondingly. 
For Weddell seals, Phe, Pro, and Glu values did not differ significantly between the Amundsen/Ross Sea and the WAP (Fig. S4). In contrast, crabeater seals had significantly lower

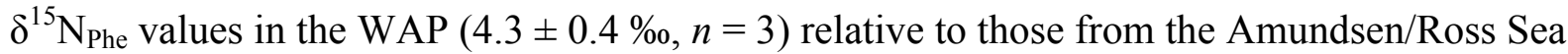
region $(6.0 \pm 0.7 \%, n=3)(p=0.04$, two-tailed student's $t$-test) (Figs. 5 and 6, Table S8). Crabeater $\delta^{15} \mathrm{~N}_{\text {Pro }}$ and $\delta^{15} \mathrm{~N}_{\text {Glu }}$ were not significantly different between the WAP $(15.9 \pm 0.5 \%$ o

391 and $15.0 \pm 0.2 \%$, respectively, $n=3$ for both) and the Amundsen/Ross Sea region (15.4 $\pm 0.6 \%$ 392 and $14.8 \pm 0.4 \%$, correspondingly, $n=3$ for both, Table S8). As with bulk isotope values,

393 spatial variation in $\delta^{15} \mathrm{~N}$ values of source amino acids for Ross seals could not be examined since 394 all but one individual were from the Amundsen Sea (Fig. S3).

Both crabeater and Weddell seals had similar $\delta^{15} \mathrm{~N}_{\text {Phe }}$ for the Amundsen/Ross Sea region, $6.0 \pm 0.7 \%$ o $(n=3)$ and $5.7 \pm 0.7 \%$ o $(n=3)$, respectively, that were significantly higher than the

$397 \delta^{15} \mathrm{~N}_{\text {Phe }}$ for Ross seals $(2.7 \pm 0.7 \%, n=6)(p$-values $<0.001$ in all cases from Bonferroni post-

398 hoc comparisons). However, crabeater seals had significantly lower $\delta^{15} \mathrm{~N}_{\text {Phe }}(4.3 \pm 0.4 \%$ o, $n=3)$ than Weddell seals $(5.7 \pm 0.4 \%, n=3)$ for the WAP ( $p=0.01$ from a two-tailed student's $t$-test).

\section{Trophic positions of Ross, Weddell, and crabeater seals}

Among species, both Ross seals $(3.5 \pm 0.2, n=6)$ and Weddell seals $(3.7 \pm 0.1, n=3)$

403 were over a full trophic level higher than crabeater seals $(2.4 \pm 0.2, n=3)(p<0.001$ from

404 Bonferroni post-hoc comparisons in both cases, restricted to Amudsen/Ross Seas where all

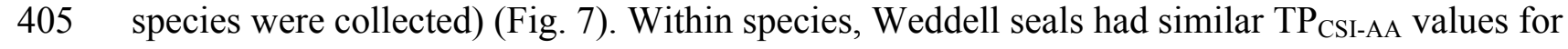
406 the WAP $(3.3 \pm 0.4, n=3)$ and Amundsen/Ross Sea region $(3.7 \pm 0.1, n=3)$. However, 407 crabeater seals had significantly higher $\mathrm{TP}_{\mathrm{CSI}-\mathrm{AA}}$ values in the WAP $(2.9 \pm 0.1, n=3)$ than the 408 Amundsen/Ross Sea region $(2.4 \pm 0.2, n=3)(p=0.03$ from a two-tailed student's $t$-test $)$. For 
409 crabeater seals, note that one subadult was included along with five adult seals in the CSI-AA

410 sample set. Although some significant variation in bulk $\delta^{15} \mathrm{~N}$ values was observed across

411 different age classes for this species (see Supplementary Material), the $\mathrm{TP}_{\mathrm{CSI}-\mathrm{AA}}$ value of the

412 subadult from the Amundsen/Ross sea region (2.3) was indistinguishable from those of the adults

413 from this region $(2.4 \pm 0.2, n=2)$. Finally, we note that there were some significant differences

414 in the bulk $\delta^{15} \mathrm{~N}$ values of Weddell seal age classes (discussed in the Supplementary Material),

415 but only samples from adults are used in our CSI-AA subset.

\section{DISCUSSION}

Ross, Weddell, and crabeater seal bulk isotope values in our study were similar to those 420 reported in earlier work on these species for our study region (Burns et al. 1998, Zhao et al.

421 2004, Aubail et al. 2011, Goetz et al. 2017, Botta et al. 2018), after correction for isotopic offsets 422 for different tissue types (Table S10). These new bulk isotope results are especially valuable for 423 Ross seals since very little isotopic measurements exist to date. Our bulk $\delta^{15} \mathrm{~N}$ values, like those 424 of prior studies (Rau et al. 1992, Burns et al. 1998, Zhao et al. 2004, Aubail et al. 2011, Cipro et 425 al. 2012, and Hückstädt et al. 2012a), all point to Ross seals being at an intermediate trophic 426 position between those of Weddell and crabeater seals. In the following discussion we explore 427 the trophic positions, diets, and foraging habitats of these three seal species using novel CSI-AA 428 data to help interpret our bulk isotope data. 
Both Weddell and crabeater seals showed spatial patterns in their bulk $\delta^{13} \mathrm{C}$ values.

432 Weddell and crabeater seals had significantly higher $\delta^{13} \mathrm{C}$ values in the WAP than the Amundsen 433 and Ross Seas. As this carbon isotope gradient occurs in Weddell and crabeater seals at different 434 trophic levels, it is likely driven by changes in baseline $\delta^{13} \mathrm{C}$ values. Prior research has shown 435 that $\delta^{13} \mathrm{C}$ values decrease with increasing latitude in the West Antarctic as a result of increasing $436 \mathrm{CO}_{2}$ solubility with decreasing sea surface temperatures (Cherel and Hobson 2007, Quillfeldt et 437 al. 2010, Brault et al. 2018). Thus, the spatial variation in the bulk $\delta^{13} \mathrm{C}$ values of these two 438 species likely predominantly reflects the sea surface temperature gradient in the West Antarctic, 439 with colder temperatures in the higher latitude Amundsen and Ross Sea compared to the warmer, 440 lower latitude WAP. The difference in sea surface temperatures of the WAP and Ross Sea 441 (Ducklow et al. 2007, Ducklow et al. 2012, Smith et al. 2014) has been shown to contribute to an $442 \sim 2 \%$ decrease in the $\delta^{13} \mathrm{C}_{\text {baseline }}$ between these regions (Brault et al. 2018), similar to the offset

443 between the WAP and Ross Sea bulk $\delta^{13} \mathrm{C}$ values that we observe for Weddell and crabeater 444 seals (2.0\%o and 2.1\%, respectively).

445 Weddell and crabeater seals showed different spatial patterns in their bulk $\delta^{15} \mathrm{~N}$ values 446 across West Antarctica. Weddell seals showed no spatial patterns in bulk $\delta^{15} \mathrm{~N}$ values across the 447 study region, Crabeater seals had significantly lower bulk $\delta^{15} \mathrm{~N}$ values in the WAP than the 448 Amundsen and Ross Seas. A spatial gradient in $\delta^{15} \mathrm{~N}_{\text {baseline }}$ in the Southern Ocean has been 449 detected by previous research, and likely reflects changes in nutrient utilization and primary 450 productivity (DiFiore et al. 2006, DiFiore et al. 2009, Brault et al. 2018). A lower $\delta^{15} \mathrm{~N}_{\text {baseline }}(\sim 2$ $451 \%$ ) in the WAP compared to the Amundsen and Ross Seas was found in a study of zooplankton 452 (Brault et al. 2018); this is similar to the difference observed here between WAP and 453 Amundsen/Ross Sea crabeater seal $\delta^{15} \mathrm{~N}_{\text {Phe values }}\left(1.7 \%\right.$ ). This difference in $\delta^{15} \mathrm{~N}_{\text {baseline values }}$ 
454 appears to reflect the relative proportion of oceanic versus coastal production across the West

455 Antarctic (DiFiore et al. 2006, DiFiore et al. 2009, Brault et al. 2018). Baseline $\delta^{15} \mathrm{~N}$ values

456 likely increase from oceanic to coastal areas due to increasing productivity and nutrient

457 drawdown towards the continent in the summer (DiFiore et al. 2006, DiFiore et al. 2009, Brault

458 et al. 2018). The WAP, with its narrow shelf, likely has a greater influence from oceanic waters

459 beyond the continental margin, whereas the Amundsen Sea and Ross Sea have wider, more

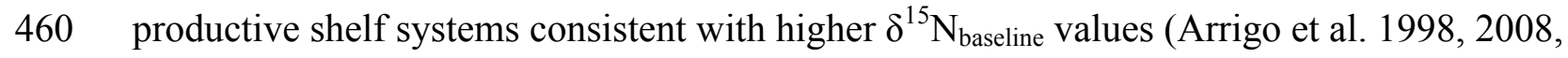

461 DiFiore et al. 2006, Smith \& Comiso 2008, DiFiore et al. 2009, Alderkamp et al. 2012, Brault et

462 al. 2018).

463 Continental shelves in Antarctica are especially productive areas compared to offshore

464 waters since both light and iron become available for phytoplankton blooms at times of coastal

465 polynya formation and increased iron inputs from various sources (e.g., melting glaciers)

466 (Gordon et al. 2000, Alderkamp et al. 2012, Arrigo et al. 2015). Although annual production in

467 the Amundsen and Ross Seas exceeds that of the WAP (Arrigo et al. 1998, 2008, Smith and

468 Comiso 2008, Alderkamp et al. 2012), localized regions in the WAP may experience high rates

469 of primary productivity comparable to those within the Amundsen and Ross Seas. For example,

470 Schmidt et al. (2003) found that Marguerite Bay in the WAP can be a "hot spot" of productivity,

471 as revealed by high phytoplankton and zooplankton $\delta^{15} \mathrm{~N}$ values. To date, examinations of

$472 \delta^{15} \mathrm{~N}_{\text {baseline variation in West Antarctica have suggested that it increases from oceanic to coastal }}$

473 waters, tracking a gradient in productivity and nutrient drawdown (Brault et al. 2018).

474 While it is likely that the observed spatial differences in Weddell and crabeater seal bulk

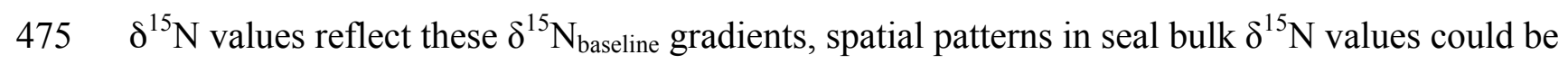

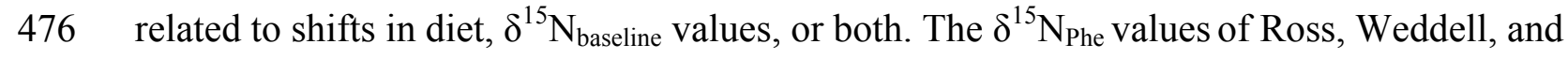


477 crabeater seals, on the other hand, reflect $\delta^{15} \mathrm{~N}_{\text {baseline, driven by spatial gradients in nutrient }}$ 478 utilization and primary productivity, without the confounding factor of trophic fractionation. As

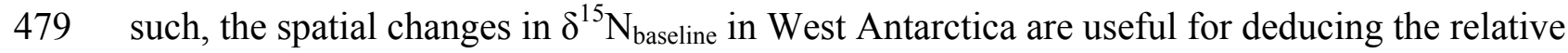
480 foraging habitats of Weddell and crabeater seals. Weddell seals from the WAP to the Ross Sea 481 consistently have the highest $\delta^{15} \mathrm{~N}_{\text {Phe values }}(5.7 \pm 0.4 \%$ for the WAP and $5.7 \pm 0.7 \%$ for the 482 Amundsen/Ross Sea region, $n=3$ in both cases) within the overall range of $\delta^{15} \mathrm{~N}_{\text {Phe }}$ for all 483 Antarctic seal (1.90\% to $6.81 \%$ ). This suggests that Weddell seals throughout West Antarctica 484 follow a similar foraging behavior in which they predominantly target the most productive 485 environments within an area (i.e., highest $\delta^{15} \mathrm{~N}_{\text {baseline; }}$ Brault et al. 2018). These are likely to be 486 coastal regions, given our understanding of the West Antarctic $\delta^{15} \mathrm{~N}_{\text {baseline }}$ gradients. Satellite 487 tracking data of different seal species in this region support this hypothesis. Costa et al. (2010) 488 used satellite data to show that in the WAP, Weddell seals (unlike crabeater seals) moved 489 minimally, foraging almost exclusively in likely highly productive coastal fjords (Schmidt et al. 490 2003, DiFiore et al. 2006, 2009). Goetz (2015), likewise, found that Weddell seal movements do 491 not extend beyond the Ross Sea continental shelf.

492 In contrast to Weddell seals, crabeater $\delta^{15} \mathrm{~N}_{\text {Phe values vary significantly across West }}$ 493 Antarctica, with higher values in the Amundsen and Ross Seas versus the WAP. These data 494 indicate that crabeater seals have greater foraging habitat flexibility than Weddell seals, and thus 495 make use of a wider range of productivity regimes. Weddell and crabeater seals also have 496 significantly different $\delta^{15} \mathrm{~N}_{\text {baseline }}$ for the WAP, which is not observed for the Amundsen/Ross Sea 497 region, pointing to environmental heterogeneity in the WAP. Our current knowledge of crabeater 498 seals indicates that this seal heavily consumes E. superba (Laws 1977, Rau et al. 1992, Burns et 499 al. 2004, Zhao et al. 2004, Burns et al. 2008, Aubail et al. 2011, Hückstädt et al. 2012a), a krill 
500 species with a distribution linked to that of sea ice. As a consequence, crabeater seals move on 501 and off the continental shelf, depending on the krill life cycle stage and seasonal ice cover (Nicol 502 2006). We hypothesize that crabeater seals move across the heterogeneous environments of the 503 WAP, at times of the year incorporating the lower off-shelf $\delta^{15} \mathrm{~N}_{\text {baseline }}$ values, in contrast with

504 Weddell seals. Such a movement pattern by crabeater seals is supported by the tracking results of 505 Costa et al. (2010). Since crabeater seals in the Amundsen/Ross Sea region have $\delta^{15} \mathrm{~N}_{\text {Phe }}$ values 506 more similar to those of Weddell seals from this area, the same interpretation would suggest that 507 crabeater seals in this region stay within the wider and more productive continental shelf areas of 508 the Amundsen and Ross Seas. Overall, our results indicate that Weddell seals have a strong 509 preference for productive coastal sites, whereas crabeater seals use more diverse habitats in West 510 Antarctica, but that their foraging patterns vary by region.

511 Ross seals sampled in the Amundsen/Ross Seas had significantly lower $\delta^{15} \mathrm{~N}_{\text {Phe values }}$

512 than both Weddell and crabeater seals from this region (Fig. 4). This result suggests that Ross 513 seals are foraging in a different region from the other two species. These low $\delta^{15} \mathrm{~N}_{\text {baseline values }}$

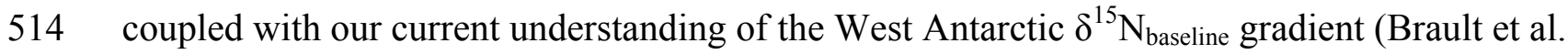

515 2018) strongly suggest that Ross seals are likely feeding much further offshore than Weddell and 516 crabeater seals, largely in the oceanic region of the Southern Ocean that experiences low nutrient 517 drawdown and low productivity relative to coastal areas (DiFiore et al. 2006, DiFiore et al. 2009, 518 Jaeger et al. 2010, Somes et al. 2010).

519 Prior research supports our hypothesis that Ross seals are largely oceanic feeders. For 520 example, Blix and Nordøy (2007) examined the foraging behavior of Ross seals via satellite521 linked dive recorders. The tags tracked the movements of 10 adult Ross seals captured off Queen 522 Maud Land (East Antarctica) just after their molt in February 2001. The animals migrated 2,000 
$523 \mathrm{~km}$ north to pelagic waters south of the Antarctic Polar Front. These Ross seals stayed in that

524 area until October when they traveled south into the pack ice (Blix and Nordøy 2007). Similarly,

525 Arcalís-Planas et al. (2015) showed that Ross seals minimally use sea ice, hauling out for only

526 short periods each year to molt (December to January) and breed (late October to mid-

527 November). They report that Ross seals are moving from 587 to $1,282 \mathrm{~km}$ off the ice edge during

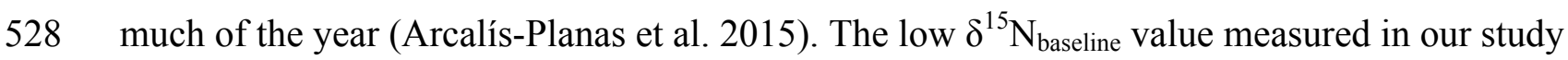

529 represents independent evidence that Ross seals are indeed are spending the majority of each

530 year foraging in less productive, oceanic waters, separate from the more coastal food webs of the

531 crabeater and Weddell seals.

533 Reevaluating trophic dynamics of Antarctic Seals

534 Differences in regional foraging habitat utilization among seals, indicated by $\delta^{15} \mathrm{~N}_{\text {phe }}$

535 between Ross seals versus crabeater and Weddell seals ( $3 \%$ ), suggest the need for a

536 reevaluation of the TP and associated food web ecology for Ross seals. Our compound-specific

537 approach allowed us to calculate trophic positions of these Antarctic seals that were internally

538 indexed to $\delta^{15} \mathrm{~N}_{\text {baseline. We found that Ross seals had TP }}$ CSI-AA values similar to those of Weddell

539 seals, both of which were significantly higher than crabeater seals. This result differed from

540 previous conclusions based on bulk $\delta^{15} \mathrm{~N}$ values, which suggested that Ross seals were at an

541 intermediate trophic position between crabeater and Weddell seals (Rau et al. 1992, Zhao et al.

542 2004, Aubail et al. 2011). Our results suggest that, like Weddell seals, Ross seals are

543 predominantly feeding on high trophic level prey, such as mid-to-deep water fish and squid, and

544 that lower trophic level prey (e.g., E. superba) are not a major part of their diets. This conclusion

545 is supported by dive records, which indicate that Ross seals forage at depths associated with 
capturing mesopelagic squid and fish (Bengtson and Stewart 1997, Blix and Nordøy 2007), and corroborate limited stomach content analyses that have reported Antarctic silverfish and glacial squid comprising their diets in varying proportions (Skinner and Klages, 1994).

551 value of crabeater seals decreases by approximately 0.5 from the WAP to the Amundsen/Ross

552 Sea region, which is substantial for a low trophic level consumer like the crabeater seal that is

553 thought to specialize on krill. Variations of this range have been shown to be significant in many

554 past studies (e.g., McCarthy et al. 2007; Batista et al. 2014), with recent ecological work

555 showing that $\mathrm{TP}_{\mathrm{CSI}-\mathrm{AA}}$ variation as small as 0.2 to 0.3 indicates real ecological change (Ostrom et

556 al. 2017). This pattern is not likely driven by differences in age class across regions as all but one

557 crabeater seal from both regions were adults. The WAP has been experiencing increased krill

558 fishing pressure, a resurgence in baleen whales (competitors for krill), and dramatic reductions in 559 sea ice extent as a function of rapid regional warming, all of which have negative effects on $E$.

560 superba abundance (Ducklow et al. 2007, Trivelpiece et al. 2011, Ducklow et al. 2012, Nicol et 561 al. 2012). Perhaps these environmental changes have decreased the availability of krill for

562 crabeater seals in this area, causing crabeater seals to supplement their diet with fish in the WAP 563 relative to the Amundsen/Ross Sea region.

564 Alternatively, the regional differences in crabeater seal $\mathrm{TP}_{\mathrm{CSI}-\mathrm{AA}}$ values could be the 565 result of bottom-up effects. Prior research has shown omnivorous behaviors by E. superba in the 566 WAP and Drake Passage regions, possibly contributing to a higher euphausiid TP in this region 567 than other areas of the Antarctic (Schmidt et al. 2006). However, euphausiid omnivory in the 568 Ross Sea has also been suggested (Hopkins 1987, Pinkerton et al. 2010), and it is possible that 
omnivory by this taxon varies in time and space (Schmidt et al. 2006). Given these uncertainties,

570 it is not possible to definitively assess the relative roles of shifts in diet versus krill omnivory to

571 our observed spatial gradient of crabeater seal TP $\mathrm{CSI}_{-\mathrm{AA}}$.

\section{CONCLUSIONS}

Our work using bulk and amino acid isotope analyses revealed significant variability in

576 the foraging habitats and trophic dynamics of three important Antarctic seal species in the West

577 Antarctic. Ross seals are foraging in a low productivity, oceanic food web far offshore from that

578 of crabeater and Weddell seals. Crabeater and Weddell seals are foraging within similar food

579 webs closer to shore, but isotopic data suggest that crabeater seals are likely following sea ice to

580 capture E. superba, while Weddell seals target the most productive, near-shore areas within the

581 western Antarctic to take prey. In addition, our CSI-AA data revealed that Ross seals occupy a

582 higher trophic position than originally thought, equivalent to Weddell seals and greater than that

583 of crabeater seals. Additionally, since bulk isotope-based TP estimates are unable to account for

584 varying baseline $\delta^{15} \mathrm{~N}$ values, we hypothesize that the strong baseline changes across the

585 environments inhabited by these species are responsible for this underestimate of TP. This study

586 will begin to reshape our understanding of Ross seal foraging ecology while also highlighting the

587 challenges and potential solutions to accounting for variability in baseline and trophic dynamics

588 when interpreting consumer isotope data in studies of foraging ecology. 
Antarctic Seal Foraging Ecology

\section{ACKNOWLEDGEMENTS}

Dyke Andreasen, Colin Carney, Elizabeth Gier, Stephanie Christensen, Jonathan Nye,

and Aaron Rosenfield provided considerable assistance with method development and the

595 laboratory analyses entailed in this study. The crew of $R V$ Oden was extremely accommodating and helpful in completing our sampling protocols. The support staffs of McMurdo and Palmer

597 Stations, similarly, gave us considerable assistance in performing our sample collections. The

598 National Science Foundation (NSF) granted our funding for this study (NSF ANT-1142108).

599 Drs. Elizabeth Canuel, Rebecca Dickhut, and Andrew Wozniak helped with the importation of 600 samples (Permit No. 17178 from the National Marine Fisheries Service).

601

602

\section{REFERENCES}

603

604

605

606

607

608

609

Ainley DG, Siniff DB (2009) The importance of Antarctic toothfish as prey of Weddell seals in the Ross Sea. Antarct Sci 21:317-327

Alderkamp AC, Mills MM, van Dijken GL, Laan P, Thuróczy CE, Gerringa LJA, de Baar HJW, Payne CD, Visser RJW, Buma AGJ, Arrigo KR (2012) Iron from melting glaciers fuels phytoplankton blooms in the Amundsen Sea (Southern Ocean): Phytoplankton characteristics and productivity. Deep-Sea Res Part II Top Stud Oceanogr 71-76:32-48

Altabet MA, Francois R (2001) Nitrogen isotope biogeochemistry of the Antarctic Polar Frontal Zone at 170 W. Deep Sea Res Part II 48:4247-4273

Arcalís-Planas A, Sveegaard S, Karlsson O, Harding KC, Wåhlin A, Harkonen T, Teilmann J (2015) Limited use of sea ice by the Ross seal (Ommatophoca rossii), in Amundsen Sea, Antarctica, using telemetry and remote sensing data. Polar Biol 38:445-461

Arim M, Naya DE (2003) Pinniped diets inferred from scats: analysis of biases in prey occurrence. Can J Zool 81:67-73

621 
622

623

624

625

626

627

628

629

630

631

632

633

634

635

636

637

638

639

640

641

642

643

644

645

646

647

648

649

650

651

652

653

654

655

656

657

658

659

660

661

662

663

664

665

Arrigo KR, Weiss AM, Smith WO (1998) Physical forcing of phytoplankton dynamics in the southwestern Ross Sea. J Geophys Res Oceans 103:1007-1021

Arrigo KR, van Dijken GL (2003) Phytoplankton dynamics within 37 Antarctic coastal polynyas systems. J Geophys Res 108:3271

Arrigo KR, van Dijken GL, Bushinsky S (2008) Primary production in the Southern Ocean, 1997-2006. J Geophys Res Oceans 113:C08004

Arrigo KR, van Dijken GL, Strong AL (2015) Environmental controls of marine productivity hot spots around Antarctica. J Geophys Res, C, Oceans, 120:5545-5565

Atkinson A, Siegel V, Pakhomov E, Rothery P (2004) Long-term decline in krill stock and increase in salps within the southern ocean. Nature 432: 100-103

Aubail A, Teilmann J, Dietz R, Rigét F, Harkonen T, Karlsson O, Rosing-Asvid A, Caurant F (2011) Investigation of mercury concentrations in fur of phocid seals using stable isotopes as tracers of trophic levels and geographic regions. Polar Biol 34:1411-1420

Batista FC, Ravelo AC, Crusius J, Casso MA, McCarthy MD (2014) Compound specific amino acid $\delta^{15} \mathrm{~N}$ in marine sediments: A new approach for studies of the marine nitrogen cycle. Geochim Cosmochim Ac 142:553-569

Bengtson JL, Stewart BS (1997) Diving patterns of a Ross seal (Ommatophoca rossii) near the eastern coast of the Antarctic Peninsula. Polar Biol 18:214-218

Bengtson JL, Laake JL, Boveng PL, Cameron MF, Hanson MB, Stewart BS (2011) Distribution, density, and abundance of pack-ice seals in the Amundsen and Ross Seas, Antarctica. Deep Sea Res Pt II 58:1261-1276

Blix AS, Nordøy ES (2007) Ross seal (Ommatophoca rossii) annual distribution, diving behaviour, breeding and moulting, off Queen Maud Land, Antarctica. Polar Biol 30:14491458

Boecklen WJ, Yarnes CT, Cook BA, James AC (2011) On the use of stable isotopes in trophic ecology. Annu Rev Ecol Evol Syst 42:411-440

Box GE, Cox DR (1964) An analysis of transformations. J R Stat Soc Series B Stat Methodol 26:211-252

Brault EK, Koch PL, McMahon KW, Broach KH, Rosenfield AP, Sauthoff W, Loeb VJ, Arrigo KR, Smith Jr WO (2018) Carbon and Nitrogen Zooplankton Isoscapes in West Antarctica Reflect Oceanographic Transitions. Mar Ecol Prog Ser 593:29-45 
Burns JM, Trumble SJ, Castellini MA, Testa JW (1998) The diet of Weddell seals in McMurdo Sound, Antarctica as determined from scat collections and stable isotope analysis. Polar Biol $19: 272-282$

Burns JM, Costa DP, Fedak MA, Hindell MA, Bradshaw CJ, Gales NJ, McDonald B, Trumble SJ, Crocker DE (2004) Winter habitat use and foraging behavior of crabeater seals along the Western Antarctic Peninsula. Deep Sea Res Pt II 51:2279-2303

Burns JM, Hindell MA, Bradshaw CJA, Costa DP (2008) Fine-scale habitat selection of crabeater seals as determined by diving behavior. Deep Sea Res Pt II 55:500-514

Cherel Y, Hobson KA (2007) Geographical variation in carbon stable isotope signatures of marine predators: a tool to investigate their foraging areas in the Southern Ocean. Mar Ecol Prog Ser 329:281-287

Chikaraishi Y, Ogawa NO, Kashiyama Y, Takano Y, Suga H, Tomitani A, Miyashita H, Kitazato H, Ohkouchi N (2009) Determination of aquatic food-web structure based on compound-specific nitrogen isotopic composition of amino acids. Limnol Oceanogr: Methods 7:740-750

Cipro CV, Bustamante P, Taniguchi S, Montone RC (2012) Persistent organic pollutants and stable isotopes in pinnipeds from King George Island, Antarctica. Mar Pollut Bull 64:26502655

Costa DP, Hückstädt LA, Crocker DE, McDonald BI, Goebel ME, Fedak MA (2010) Approaches to studying climatic change and its role on the habitat selection of Antarctic pinnipeds. Integr Comp Biol 50: 1018-1030

de Baar HJ, Buma AG, Nolting RF, Cadée GC, Jacques G, Tréguer PJ (1990) On iron limitation of the Southern Ocean: experimental observations in the Weddell and Scotia Seas. Mar Ecol Prog Ser 65:105-122

Dellinger T, Trillmich F (1988) Estimating diet composition from scat analysis in otariid seals (Otariidae): is it reliable? Can J Zool 66:1865-1870

DiFiore PJ, Sigman DM, Trull TW, Lourey MJ, Karsh K, Cane G, Ho R (2006) Nitrogen isotope constraints on subantarctic biogeochemistry. J Geophys Res Oceans 111:C08016

DiFiore PJ, Sigman DM, Dunbar RB (2009) Upper ocean nitrogen fluxes in the Polar Antarctic Zone: Constraints from the nitrogen and oxygen isotopes of nitrate. Geochem Geophys Geosyst 10:Q11016

Ducklow, HW, Baker K, Martinson DG, Quetin LB, Ross RM, Smith RC (2007) Marine pelagic ecosystems: The west WAP. Philos Trans R Soc B Biol Sci 362:67-94 
Ducklow HW, Clarke A, Dickhut R, Doney SC, Geisz H, Huang K, Martinson DG, Meredith MP, Moeller HV, Montes-Hugo M, Schofield O, Stammerjohn SE, Steinberg D, Fraser W (2012) The marine system of the western WAP. In: Rogers AD, Johnston NM, Murphy EJ,

Germain LR, Koch PL, Harvey J, McCarthy MD (2013) Nitrogen isotope fractionation in amino acids from harbor seals: implications for compound-specific trophic position calcuations. Mar Ecol Prog Ser 482:265-277

Goetz KT, Burns JM, Hückstädt LA, Shero MR, Costa DP (2017) Temporal variation in isotopic composition and diet of Weddell seals in the western Ross Sea. Deep Sea Res II 140:36-44

Goetz KT (2015) Movement, habitat, and foraging behavior of Weddell Seals (Leptonychotes weddellii) in the western Ross Sea, Antarctic. PhD dissertation, University of California, Santa Cruz, CA.

Gordon LI, Codispoti LA, Jennings JC, Millero FJ, Morrison JM, Sweeney C (2000) Seasonal evolution of hydrographic properties in the Ross Sea, Antarctica, 1996-1997. Deep Sea Res II 47:3095-3117

Graham BS, Koch PL, Newsome SD, McMahon KW, Aurioles D (2010) Using isoscapes to trace the movements and foraging behavior of top predators in oceanic ecosystems. In: West JB, Bowen GJ, Dawson TE, Tu KP (eds) Isoscapes. Springer, Netherlands, p 299-318

Hopkins TL (1987) Midwater food web in McMurdo Sound, Ross Sea, Antarctica. Mar Biol 96:93-106

Hückstädt LA, Burns JM, Koch PL, McDonald BI, Crocker DE, Costa DP (2012a) Diet of a specialist in a changing environment: the crabeater seal along the western Antarctic Peninsula. Mar Ecol Prog Ser 455:287-301

Hückstädt LA, Koch PL, McDonald BI, Goebel ME, Crocker DE, Costa DP (2012b) Stable isotope analyses reveal individual variability in the trophic ecology of a top marine predator, the southern elephant seal. Oecologia 169:395-406

Jaeger A, Connan M, Richard P, Cherel Y (2010) Use of stable isotopes to quantify seasonal changes of trophic niche and levels of population and individual specialization in seabirds. Mar Ecol Prog Ser 401:269-277

Lake S, Burton H, van den Hoff J (2003) Regional, temporal and fine-scale spatial variation in Weddell seal diet at four coastal locations in east Antarctica. Mar Ecol Prog Ser 254:293-305

Laws RM (1977) Seals and whales of the Southern Ocean. Phil Trans R Soc Lond B 279: 81-96

Magozzi S, Yool A, Vander Zanden HB, Wunder MB, Trueman CN (2017) Using ocean models to predict spatial and temporal variation in marine carbon isotopes. Ecosphere 8:e01763-20 
McCarthy MD, Benner R, Lee C, Fogel ML (2007) Amino acid nitrogen isotopic fractionation patterns as indicators of heterotrophy in plankton, particulate, and dissolved organic matter. Geochim Cosmochim Ac 71:4727-4744

McCarthy MD, Lehman J, Kudela R (2013) Compound-specific amino acid $\delta^{15} \mathrm{~N}$ patterns in marine algae: Tracer potential for cyanobacterial vs. eukaryotic organic nitrogen sources in the ocean. Geochim Cosmochim Ac 103:104-120

McClelland JW, Montoya JP (2002) Trophic relationships and the nitrogen isotopic composition of amino acids in plankton. Ecology 83:2173-2180

McMahon KW, Hamady LL, Thorrold SR (2013) A review of ecogeochemistry approaches to estimating movements of marine animals. Limnol Oceanogr 58:697-714

McMahon KW, Thorrold SR, Elsdon TS, McCarthy MD (2015) Trophic discrimination of nitrogen stable isotopes in amino acids varies with diet quality in a marine fish. Limnol Oceanogr 60:1076-1087

McMahon, KW, McCarthy MD (2016) Embracing variability in amino acid $\delta^{15} \mathrm{~N}$ fractionation: mechanisms, implications, and applications for trophic ecology. Ecosphere 7:e01511

Minagawa M, Wada E (1984) Stepwise enrichment of ${ }^{15} \mathrm{~N}$ along food chains: Further evidence and the relation between $\delta^{15} \mathrm{~N}$ and animal age. Geochim Cosmochim Ac 48:1135-1140

Montes-Hugo M, Doney SC, Ducklow HW, Fraser W, Martinson D, Stammerjohn SE (2009) Recent changes in phytoplankton communities associated with rapid regional climate change along the western WAP. Science 323:1470-1473

Nicol S (2006) Krill, currents, and sea ice: Euphausia superba and its changing environment. Bioscience 56:111-120

Nicol S, Foster J, Kawaguchi S (2012) The fishery for Antarctic krill-recent developments. Fish Fish 13:30-40

Ohkouchi N, Chikaraishi Y, Close HG, Fry B, Larsen T, Madigan DJ, McCarthy MD, McMahon KW, Nagata T, Naito YI, Ogawa NO, Popp BN, Steffan S, Takano Y, Tayasu I, Wyatt ASJ, Yamaguchi YT, Yokoyama Y (2017) Advances in the application of amino acid nitrogen isotopic analysis in ecological and biogeochemical studies. Org Geochem 113:150-174

Ostrom PH, Wiley AE, James HF, Rossman S, Walker WA, Zipkin EF, Chikaraishi Y (2016) Broad-scale trophic shift in the pelagic North Pacific revealed by an oceanic seabird. Proc. R. Soc. B. 284:20162436

Pinkerton MH, Bradford-Grieve JM, Hanchet SM (2010) A balanced model of the food web of the Ross Sea, Antarctica. CCAMLR Sci 17:1-31 
Plötz J, Bornemann H, Bornemann H, Knust R, Schröder A, Bester M (2001) foraging behaviour of weddell seals and its ecological implications. Polar Biol 24:901-909

Ponganis PJ, Stockard TK (2007) Short Note: The Antarctic toothfish: how common a prey for Weddell seals? Antarct Sci 19:441-442

Popp BN, Graham BS, Olson RJ, Hannides CCS, Lott MJ, López-Ibarra GA, Galván-Magaña F, Fry B (2007) Insight into the trophic ecology of the yellowfin tuna, Thunnus albacares, from compound-specific nitrogen isotope analysis of proteinaceous amino acids. In: Dawson T, Siegwolf R (eds) Stable Isotopes as Indicators of Ecological Change. Elsevier, New York, p 173-190

Post DM (2002) Using stable isotopes to estimate trophic position: models, methods, and assumptions. Ecology 83:703-718

Quillfeldt P, Masello JF, McGill RAR, Adams M, Furness RW (2010) Moving polewards in winter: a recent change in the migratory strategy of a pelagic seabird? Front Zool 7:15

R Core Team (2014). R: A language and environment for statistical computing. Foundation for Statistical Computing, Vienna, Austria

Rau GH, Sweeney RE, Kaplan IR (1982) Plankton 13C: 12C ratio changes with latitude: differences between northern and southern oceans. Deep Sea Res Pt I 29:1035-1039

Rau GH, Ainley DG, Bengtson JL, Torres JJ, Hopkins TL $(1992){ }^{15} \mathrm{~N} /{ }^{14} \mathrm{~N}$ and ${ }^{13} \mathrm{C} /{ }^{12} \mathrm{C}$ in Weddell Sea birds, seals, and fish: implications for diet and trophic structure. Mar Ecol Prog Ser $84: 1-8$

Reeves RR (2008) Guide to marine mammals of the world. Knopf Doubleday Publishing Group, New York

Schlitzer R (2015) Ocean Data View (ODV) version (4.7.4). http://odv.awi.de

Schmidt K, Atkinson A, Stübing D, McClelland JW, Montoya J P, Voss M (2003) Trophic relationships among Southern Ocean copepods and krill: some uses and limitations of a stable isotope approach. Limnol Oceanogr 48:277-289

Schmidt K, Atkinson A, Petzke KJ, Voss M, Pond DW (2006) Protozoans as a food source for Antarctic krill, Euphausia superba: Complementary insights from stomach content, fatty acids, and stable isotopes. Limnol Oceanogr 51:2409-2427

Sherwood OA, Lehmann MF, Schubert CJ, Scott DB, McCarthy MD (2011) Nutrient regime shift in the western North Atlantic indicated by compound-specific $\delta^{15} \mathrm{~N}$ of deep-sea gorgonian corals. P Natl Acad Sci USA 108:1011-1015 
Skinner JD, Klages NTW (1994) On some aspects of the biology of the Ross seal Ommatophoca rossii from King Haakon VII Sea, Antarctica. Polar Biol 14:467-472

Smith WO, Comiso JC (2008). Influence of sea ice on primary production in the Southern Ocean: A satellite perspective. J Geophys Res Oceans 113:C05S93

Smith Jr WO, Ainley DG, Arrigo KR, Dinniman MS (2014) The Oceanography and Ecology of the Ross Sea. Annu Rev Mar Sci 6:469-487

Somes CJ, Schmittner A, Galbraith ED, Lehmann MF, Altabet MA, Montoya JP, Letelier RM, Mix AC, Bourbonnais A, Eby M (2010) Simulating the global distribution of nitrogen isotopes in the ocean. Global Biogeochem Cycles 24:16

Staniland IJ (2002) Investigating the biases in the use of hard prey remains to identify diet composition using Antarctic fur seals (Arctocephalus gazella) in captive feeding trials. Mar Mamm Sci 18:223-243

Trivelpiece WZ, Hinke JT, Miller AK, Reiss CS, Trivelpiece SG, Watters GM (2011)Variability in krill biomass links harvesting and climate warming to penguin population changes in Antarctica. Proc Natl Acad Sci USA 108:7625-7628

Vander Zanden MJ, Clayton MK, Moody EK, Solomon CT, Weidel BC (2015) Stable isotope turnover and half-life in animal tissues: a literature synthesis. PloS ONE 10:e0116182

Yonezaki S, Kiyota M, Baba N, Koido T, Takemura A (2003) Size distribution of the hard remains of prey in the digestive tract of northern fur seal (Callorhinus ursinus) and related biases in diet estimation by scat analyses. Mamm Study 28:97-102

Zhao L, Castellini MA, Mau TL, Trumble SJ (2004) Trophic interactions of Antarctic seals as determined by stable isotope signatures. Polar Biol 27:368-373 
Antarctic Seal Foraging Ecology

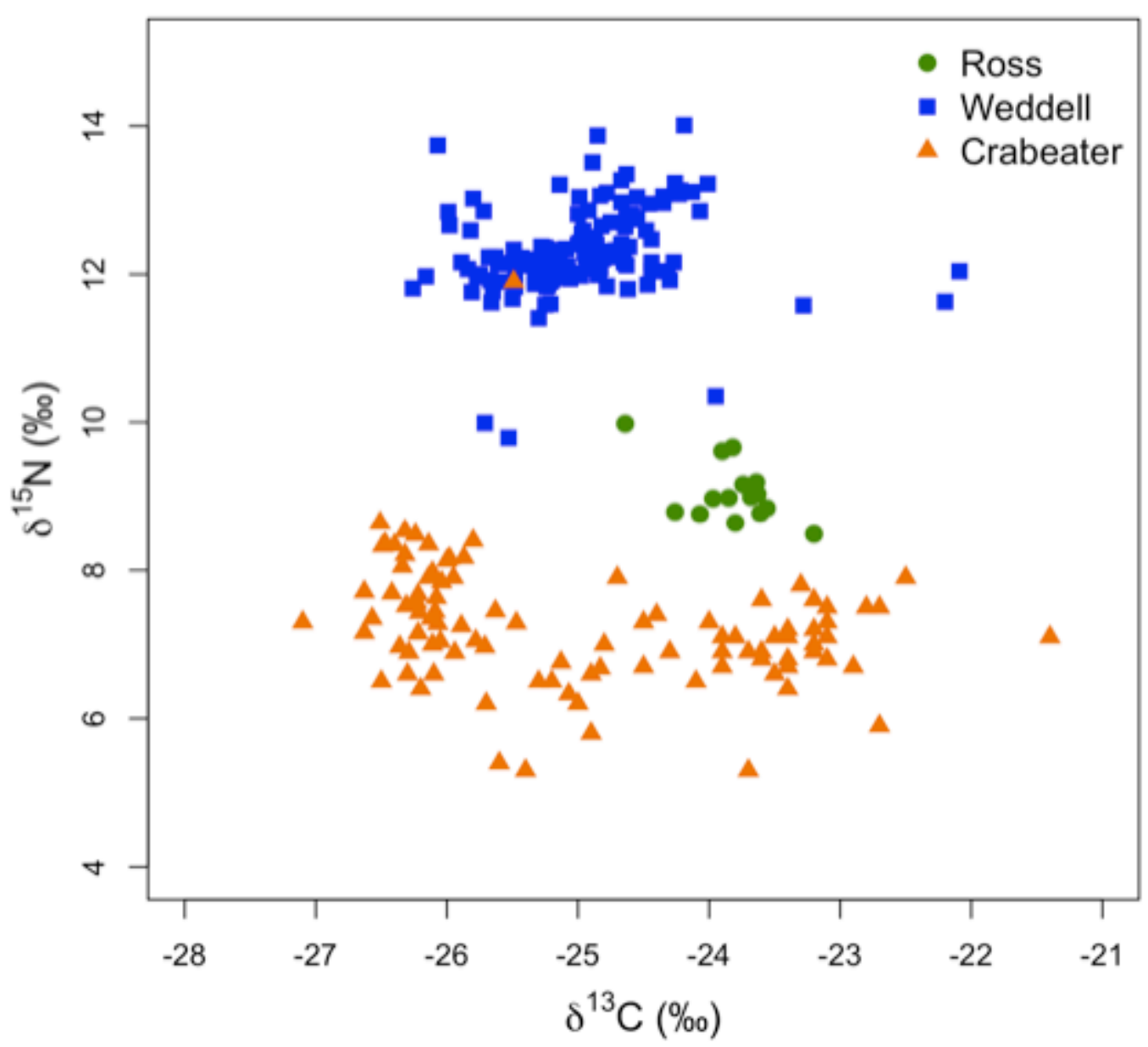

884

885

886

887
Fig. 1. Bulk $\delta^{15} \mathrm{~N}$ values versus $\delta^{13} \mathrm{C}$ values for Ross seals (green circles), Weddell (blue squares), and crabeater (orange triangles) in the West Antarctic. 
Antarctic Seal Foraging Ecology

888
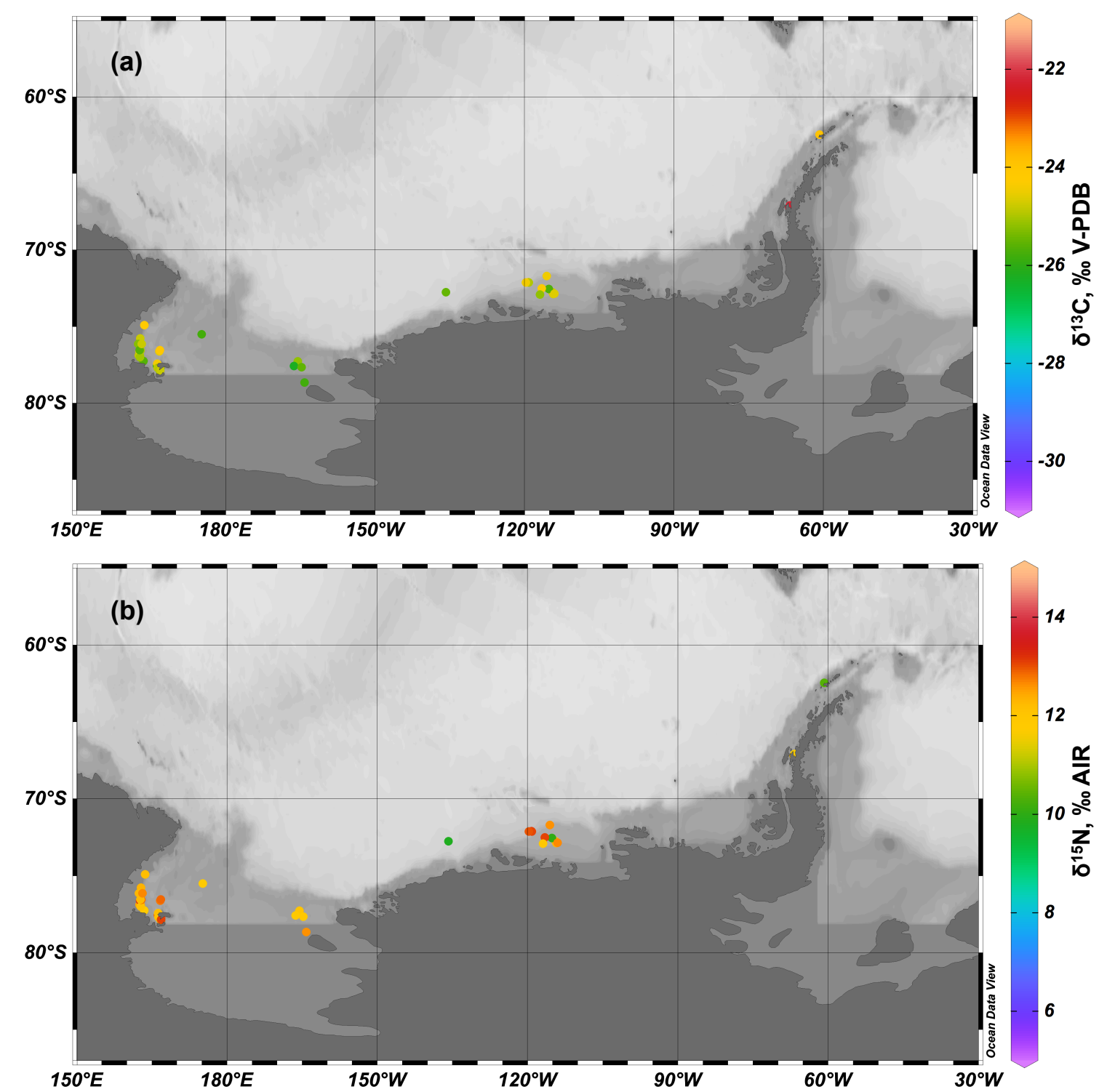

890 Fig. 2. Spatial variation in $\delta^{13} \mathrm{C}(\mathrm{a})$ and $\delta^{15} \mathrm{~N}(\mathrm{~b})$ values of Weddell seals. Figures were produced in Ocean 891 Data View 4.7.4 (Schlitzer 2015).

892 
Antarctic Seal Foraging Ecology

893

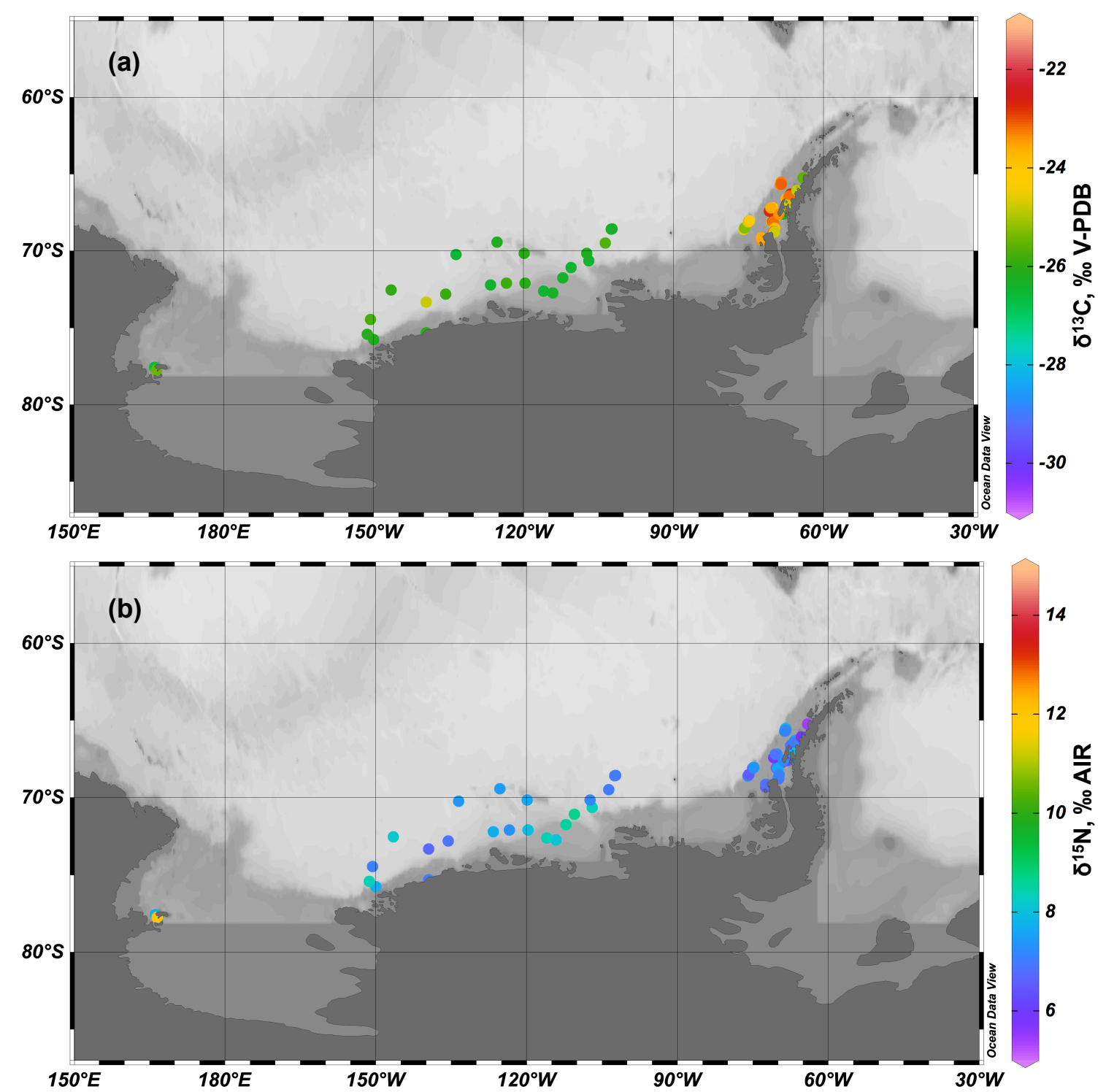

895 Fig. 3. Spatial variation in $\delta^{13} \mathrm{C}(\mathrm{a})$ and $\delta^{15} \mathrm{~N}$ (b) values of crabeater seals. Figures were produced in Ocean 896 Data View 4.7.4 (Schlitzer 2015).

897 


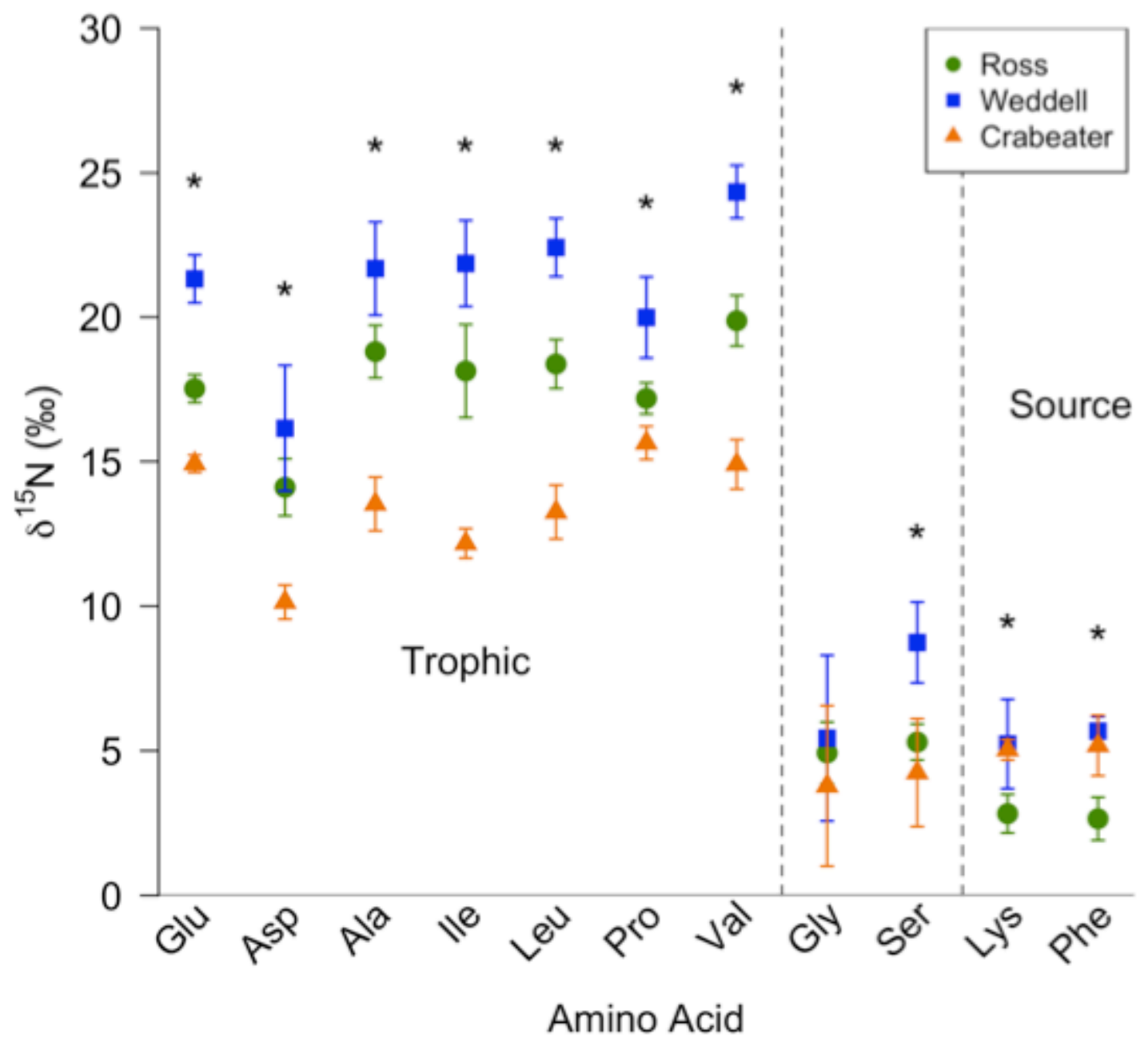

Fig. 4. Mean $\delta^{15} \mathrm{~N}$ values ( $\pm 1 \mathrm{SD}$ ) of amino acids for Ross (green circles), Weddell (blue squares), and crabeater (orange triangles) seals. Significant differences $(p<0.05)$ among species for an amino acid are indicated with asterisks. Amino acids are divided into trophic and source amino acids, with Gly and Ser separate given uncertainty in their classification for marine mammals (McMahon and McCarthy 2016). 
Antarctic Seal Foraging Ecology

905
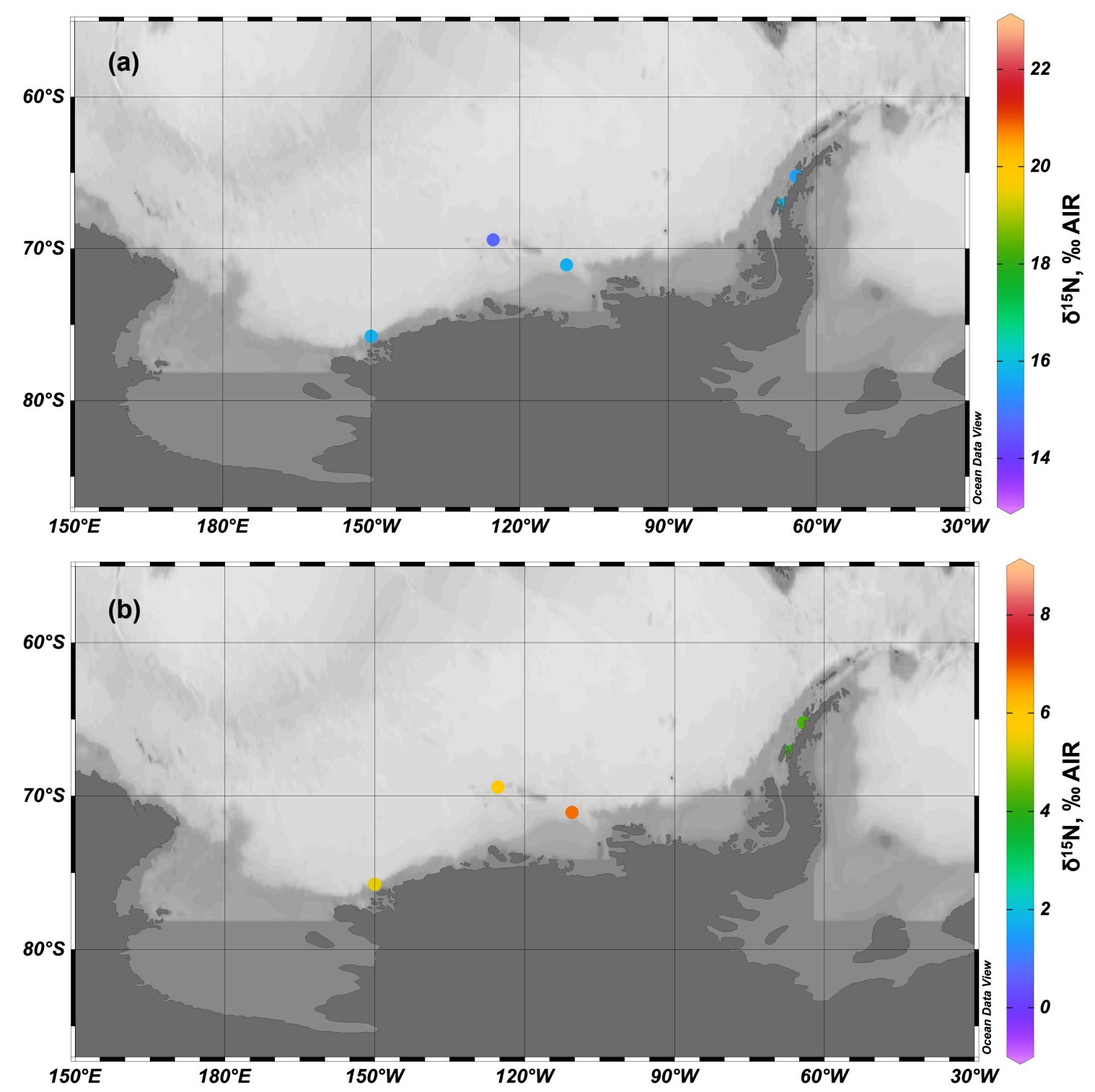

Fig. 5. Spatial variation in $\delta^{15} \mathrm{~N}$ values of Pro (a) and Phe (b) values for crabeater seals. Figures were 908 produced in Ocean Data View 4.7.4 (Schlitzer 2015).

909 
Antarctic Seal Foraging Ecology

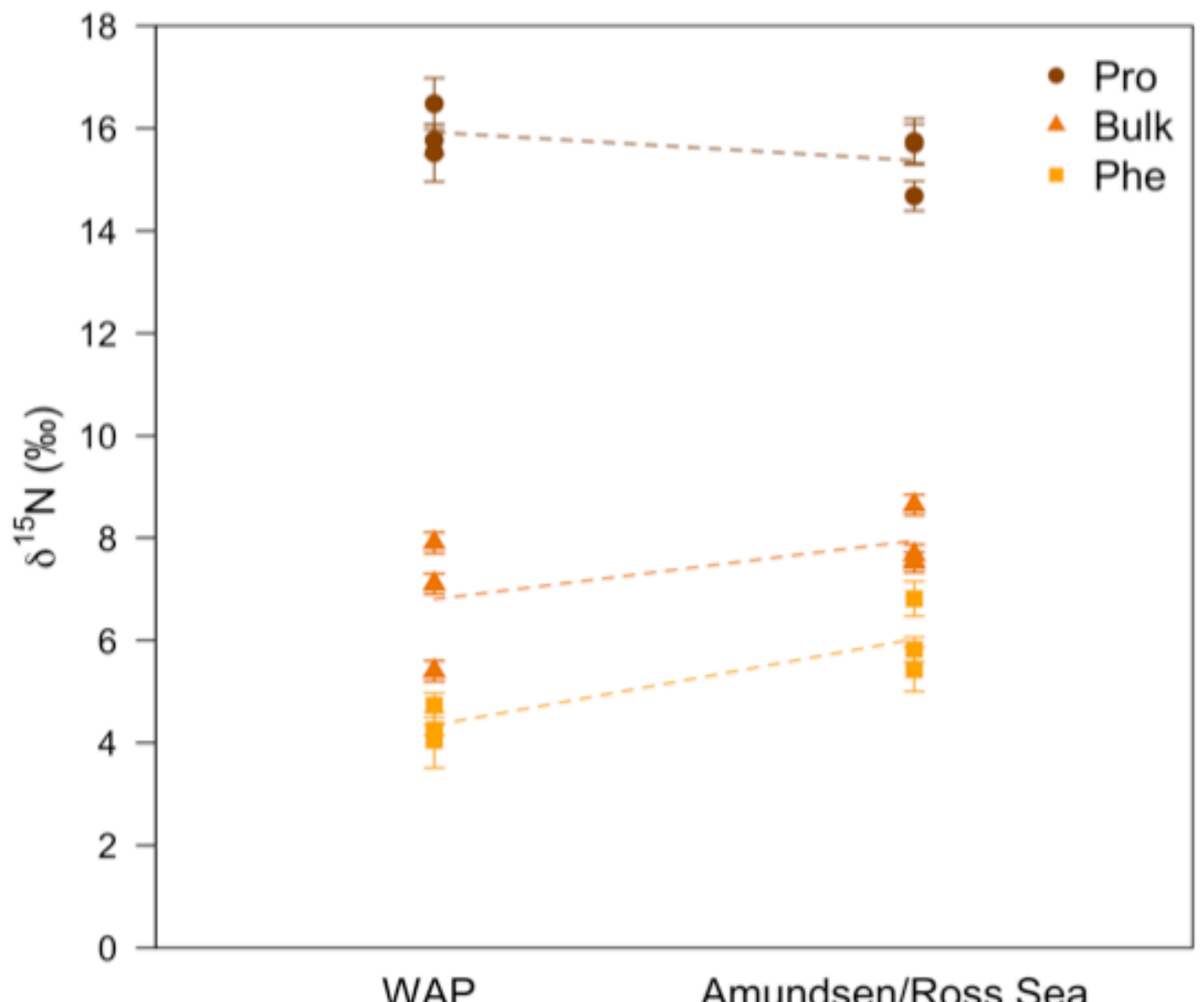

910 911

912

913

914

915
Fig. 6. Comparison of $\delta^{15} \mathrm{~N}$ values (mean $\pm 1 \mathrm{SD}$ ) of Pro, bulk material, and Phe for crabeater seals. Dark orange circles, medium orange triangles, light orange squares represent Pro, bulk, and Phe $\delta^{15} \mathrm{~N}$ values, respectively. Bulk $\delta^{15} \mathrm{~N}$ values represent whole blood, with corrections applied if the given sample type analyzed was not whole blood. 


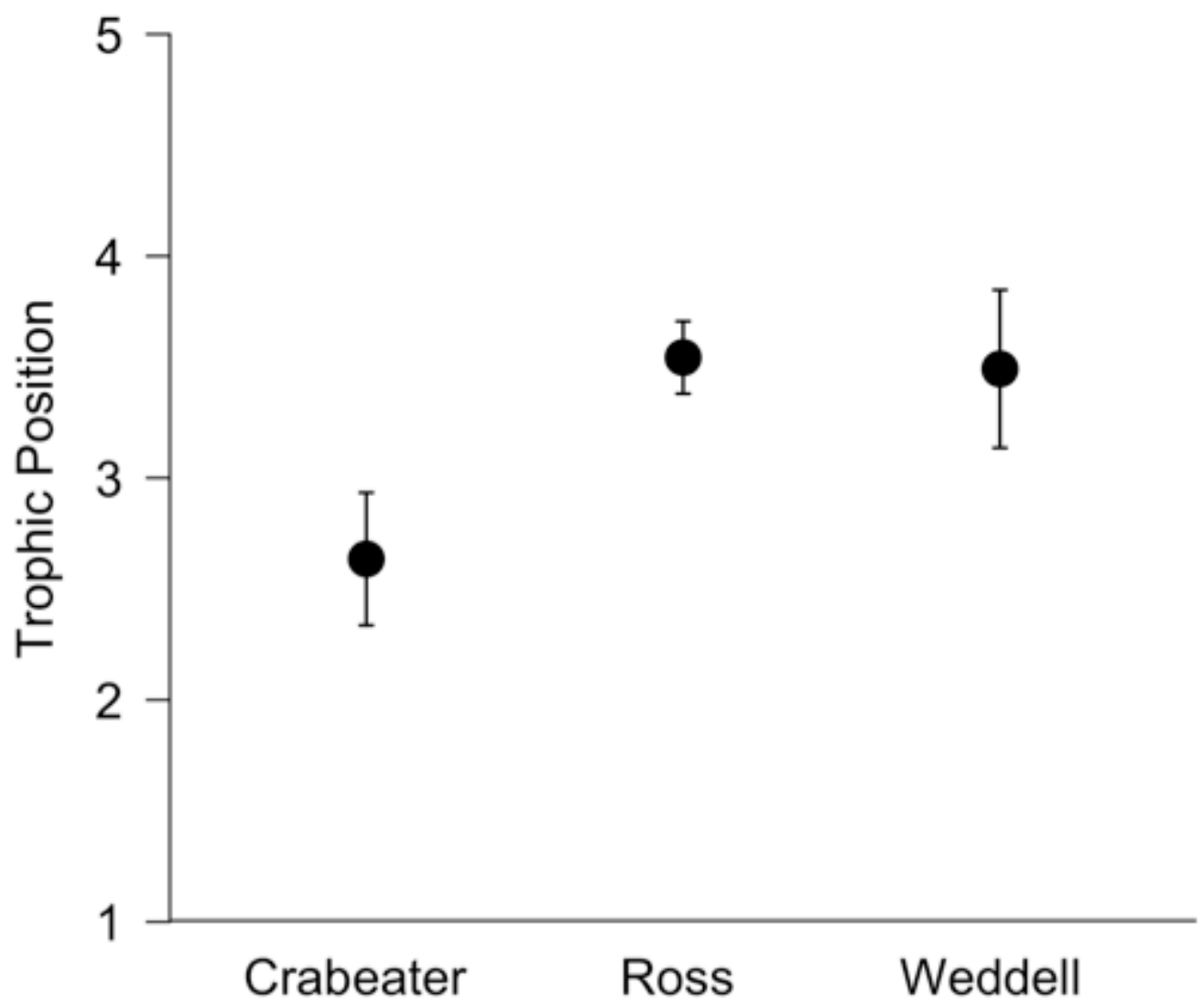

916

917

918

919
Fig. 7. Trophic position estimates (mean $\pm 1 \mathrm{SD}$ ) for crabeater, Ross, and Weddell seals from the Amundsen and Ross Seas. Trophic positions were calculated based on Pro and Phe $\delta^{15} \mathrm{~N}$ values. 
SUPPLEMENTAL MATERIAL

4 Relationships of bulk $\delta^{13} \mathrm{C}$ and $\delta^{15} \mathrm{~N}$ values with gender, sampling period, age class, and body mass of the Antarctic seals

Sampling period, gender, and age class have no significant effects on the bulk $\delta^{13} \mathrm{C}$ values of Ross Seals (Figs. S5 and S6). However, there is a significant, but weak negative

8 relationship between body mass and $\delta^{13} \mathrm{C}$ values $\left(\mathrm{R}^{2}\right.$ value of 0.3 from a linear regression

9 analysis, Fig. S6). Sampling period, gender, age class, and body mass all have no significant

10 effects on the bulk $\delta^{15} \mathrm{~N}$ values of Ross seals (Figs. S5 and S6).

11 For Weddell seals, sampling period, gender, and body mass have no significant effects on 12 bulk $\delta^{13} \mathrm{C}$ values (Figs. S7 and S8). Adult Weddell seals have significantly higher bulk $\delta^{13} \mathrm{C}$ 13 values $(-24.9 \pm 0.6 \%, n=93)$ than juveniles $(-25.2 \pm 0.6 \%, n=17)$ and subadults $(-25.4 \pm 0.5 \%$, $14 n=15)(p=0.002$ in both cases). Sampling period, gender, and body mass have no significant 15 effects on bulk $\delta^{15} \mathrm{~N}$ values (Figs. S7, and S8). However, Weddell bulk $\delta^{15} \mathrm{~N}$ values are 16 significantly lower in subadults $(11.9 \pm 0.7 \%, n=15)$ than juveniles $(12.6 \pm 0.6 \%, n=17)$ and 17 adults $(12.3 \pm 0.6 \%, n=93)$ ( $p$-values of 0.02 and 0.004 , correspondingly, from Bonferroni post18 hoc comparisons) (Fig. S7).

19 Crabeater seal $\delta^{13} \mathrm{C}$ values are not affected significantly by sampling period or gender

20 (Fig. S9). Adult crabeater seals have significantly higher $\delta^{13} \mathrm{C}$ values $(-24.6 \pm 1.3 \%$, $n=76)$ than 21 subadults $(-26.3 \pm 0.2 \%, n=10)$ and juveniles $(-26.2 \pm 0.4 \%, n=11)$ from Bonferroni post-hoc 22 comparisons $\left(p<0.001\right.$ in both cases) (Fig. S9). Additionally, crabeater seal $\delta^{13} \mathrm{C}$ values increase 23 significantly with increasing body mass ( $\mathrm{R}^{2}$ value of 0.4 from a linear regression analysis) (Fig. 
$24 \mathrm{~S} 10$ ). The $\delta^{15} \mathrm{~N}$ values of crabeater seals do not vary significantly with gender (Fig. S9). One

25 significant difference occurs across sampling periods: Amundsen Sea $\delta^{15} \mathrm{~N}$ values are

26 significantly higher for the austral summer $2007 / 08$ sampling $(8.1 \pm 0.4 \%, n=14)$ than the

27 austral summer 2010/11 sampling $(7.3 \pm 0.6 \%$ o, $n=21)(p<0.001$ from Bonferroni post-hoc

28 comparisons). Adult crabeater seals have significantly lower $\delta^{15} \mathrm{~N}$ values $(7.0 \pm 0.8 \%, n=76)$

29 than subadult animals $(8.3 \pm 0.4 \%, n=10, p<0.0001$ for the Bonferroni post-hoc comparison)

30 and juvenile seals $(7.8 \pm 0.3 \%, n=11, p=0.01$ for the Bonferroni post-hoc comparison) (Fig.

31 S9). The $\delta^{15} \mathrm{~N}$ values significantly increase with decreasing body mass (Fig. S10, $\mathrm{R}^{2}$ value of 0.4

32 from a linear regression analysis).

33 Discussion of relationships of bulk isotope values with gender, sampling period, age class,

34 and body mass of the Antarctic seals

35 Our Ross seal bulk $\delta^{13} \mathrm{C}$ and $\delta^{15} \mathrm{~N}$ results suggest a similar diet and foraging region across

36 different genders and age classes. In contrast, the significant relationship between body mass and

$37 \delta^{13} \mathrm{C}$ (increasing $\delta^{13} \mathrm{C}$ values with decreasing body mass) suggests that Ross seals of different

38 sizes are foraging in slightly different areas. However, no significant relationship exists between

39 body mass and phenylalanine (Phe) $\delta^{15} \mathrm{~N}$ value for Ross seals, which varies across different

40 environments as described in the main text. Zhao et al. (2004) found no significant effects of age

41 or sex on Ross seal $\delta^{13} \mathrm{C}$ and $\delta^{15} \mathrm{~N}$ values.

42 Our Weddell and crabeater seal results show no significant effects of gender on $\delta^{13} \mathrm{C}$ and

$43 \quad \delta^{15} \mathrm{~N}$ values, indicating that foraging area and diet do not differ across genders for these species.

44 This finding is consistent with the results of Zhao et al. (2004) and Burns et al. (1998) for

45 crabeater and Weddell seals, respectively. However, Zhao et al. (2004) reported that male

46 Weddell seals have significantly higher $\delta^{13} \mathrm{C}$ and $\delta^{15} \mathrm{~N}$ values than females. 
Weddell seal bulk $\delta^{13} \mathrm{C}$ values of adults are significantly higher than those of juveniles and subadults, suggesting that these animals vary their foraging region with age. In contrast, Zhao et al. (2004) and Aubail et al. (2011) found no significant variation in bulk $\delta^{13} \mathrm{C}$ values

50 across Weddell seal age classes. However, Goetz et al. (2017) found increasing $\delta^{13} \mathrm{C}$ values with 51 age for Weddell seals from analysis of red blood cells (RBC), consistent with our finding. Our

52 results point to adult crabeater seals foraging in a different area than subadults and juveniles,

53 perhaps further offshore given their higher $\delta^{13} \mathrm{C}$ values, as well as the positive relationship

54 between body mass and $\delta^{13} \mathrm{C}$ value for this species. Likewise, Aubail et al. (2011) found

55 significantly higher $\delta^{13} \mathrm{C}$ values in crabeater adults than juveniles, and Hückstädt et al. (2012)

56 found $\delta^{13} \mathrm{C}$ values significantly increasing with increasing crabeater seal body mass. In contrast, 57 Zhao et al. (2004) found no significant variability in $\delta^{13} \mathrm{C}$ values across age groups.

In this study, both Weddell and crabeater seals have significant variability in $\delta^{15} \mathrm{~N}$ values across age classes. For crabeater seals, our finding of significantly lower $\delta^{15} \mathrm{~N}$ values in adults than juveniles is supported by the results of Aubail et al. (2011). The observed bulk isotope

61 variation for Weddell and crabeater seals in this study could have resulted from differences in

62 foraging regions, diet, or both between the various age classes. We did not attempt to explore the

63 drivers of $\delta^{15} \mathrm{~N}$ variations across age classes of Weddell and crabeater seals further in our

64 compound-specific isotope analysis of amino acids (CSI-AA) since limitations entailed in this 65 analysis (i.e., expense and extensive laboratory processing) did not allow for aminio acid $\delta^{15} \mathrm{~N}$ 66 measurements from a sufficient number of samples for such an investigation. For Weddell seals, 67 we only conducted CSI-AA on tissues from adults. We performed CSI-AA on one subadult and 68 five adults for crabeater seals. The subadult had a higher Phe $\delta^{15} \mathrm{~N}$ value $(6.8 \%$ ) relative to that 69 of the adults $(5.6 \pm 0.3 \%$ ) for the Amundsen/Ross sea region. The nitrogen isotope values of Pro 
70 and Glu for the subadult (15.7\%o and $15.1 \%$, respectively) were slightly higher than Pro and

71 Glu $\delta^{15} \mathrm{~N}$ values of adults $(15.2 \pm 0.8 \%$ and $14.7 \pm 0.5 \%$ ) for the Amundsen and Ross Seas.

72 This result indicates the higher bulk $\delta^{15} \mathrm{~N}$ values of subadult than adult crabeater seals may be

73 driven by the former using a habitat with moderately higher baseline $\delta^{15} \mathrm{~N}$ values and, perhaps,

74 nitrogen drawdown than the latter. However, CSI-AA must be conducted on considerably more

75 crabeater seal samples before $\delta^{15} \mathrm{~N}$ variation across age classes can be clearly established and the

76 possible causes can be identified.

77 The results of other studies measuring bulk $\delta^{15} \mathrm{~N}$ values of Weddell and crabeater seals

78 differed from our findings. Goetz et al. (2017) found increasing $\delta^{15} \mathrm{~N}$ values with increasing

79 Weddell seal age. Zhao et al. (2004) compared $\delta^{15} \mathrm{~N}$ values of Weddell seal pups, juveniles,

80 subadults, and adults, and found only one significant result: adults have higher $\delta^{15} \mathrm{~N}$ values than

81 subadults. Aubail et al. (2011) reported no significant difference across Weddell seal age groups,

82 which included juveniles and adults. For crabeater seals, Zhao et al. (2004) found no significant

83 variability in $\delta^{15} \mathrm{~N}$ values of pups, juveniles, subadults, and adults. Overall, the effects of age, as

84 well as gender, on the isotopic values of crabeater and Weddell seals vary across the research to

85 date. Furthermore, isotope baseline variability may contribute to the differences in bulk isotope

86 values across age groups or genders, as mentioned above and discussed in detail in the main text.

87

88

89

90

91

92 
Antarctic Seal Foraging Ecology

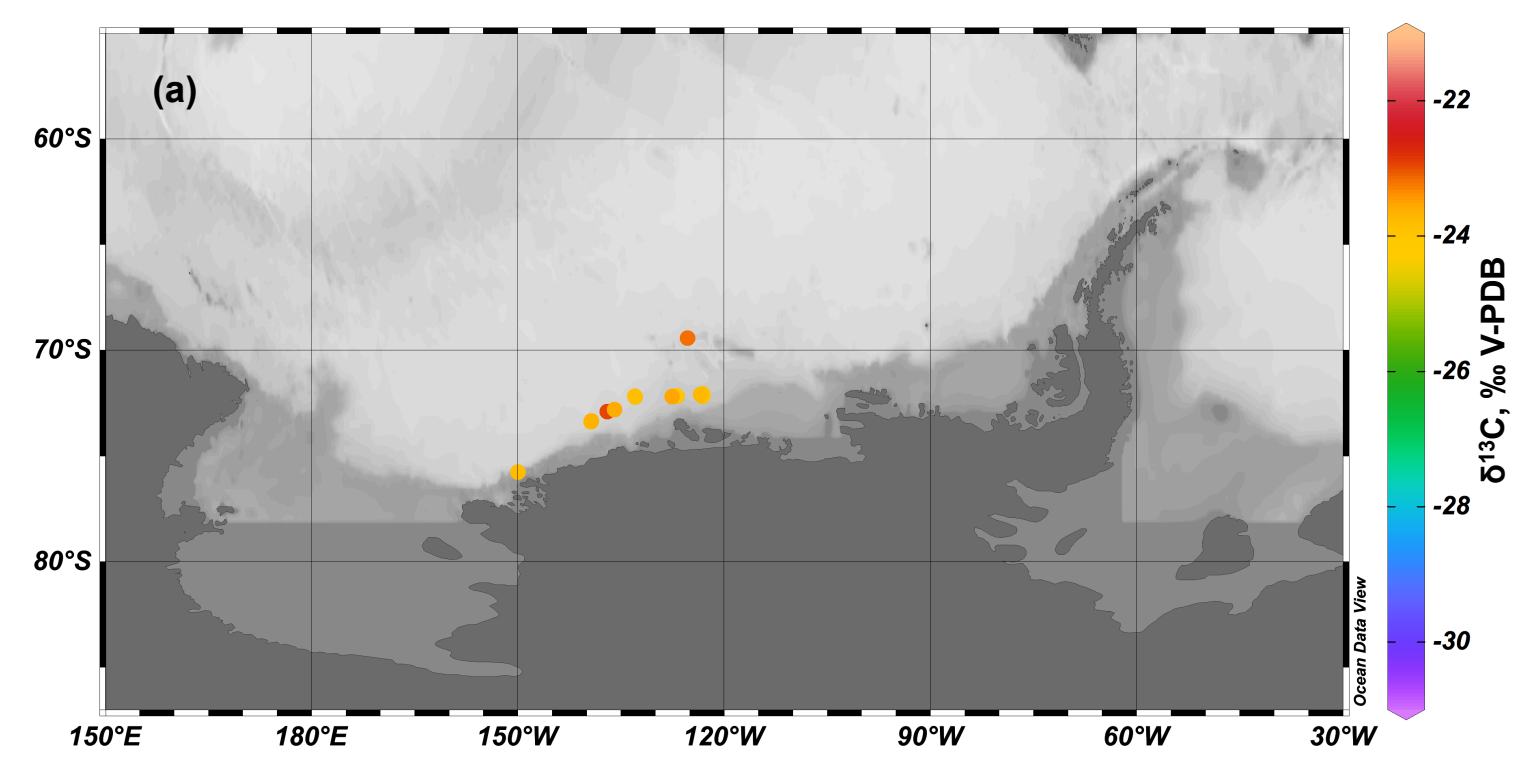

94

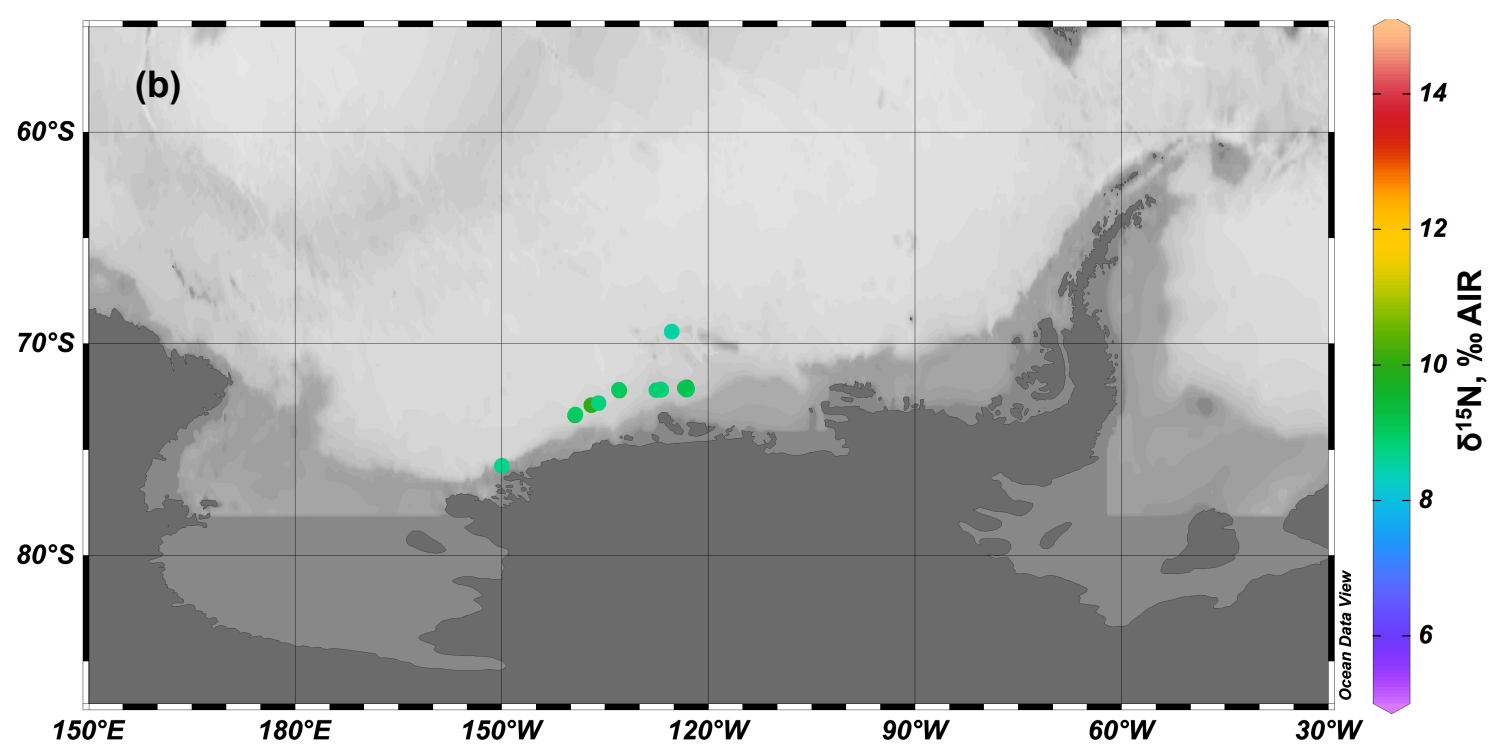

95 Fig. S1. Spatial variation in bulk $\delta^{13} \mathrm{C}(\mathrm{a})$ and $\delta^{15} \mathrm{~N}$ (b) values of Ross seals. Figures were produced in

96 Ocean Data View 4.7.4 (Schlitzer 2015). 
Antarctic Seal Foraging Ecology

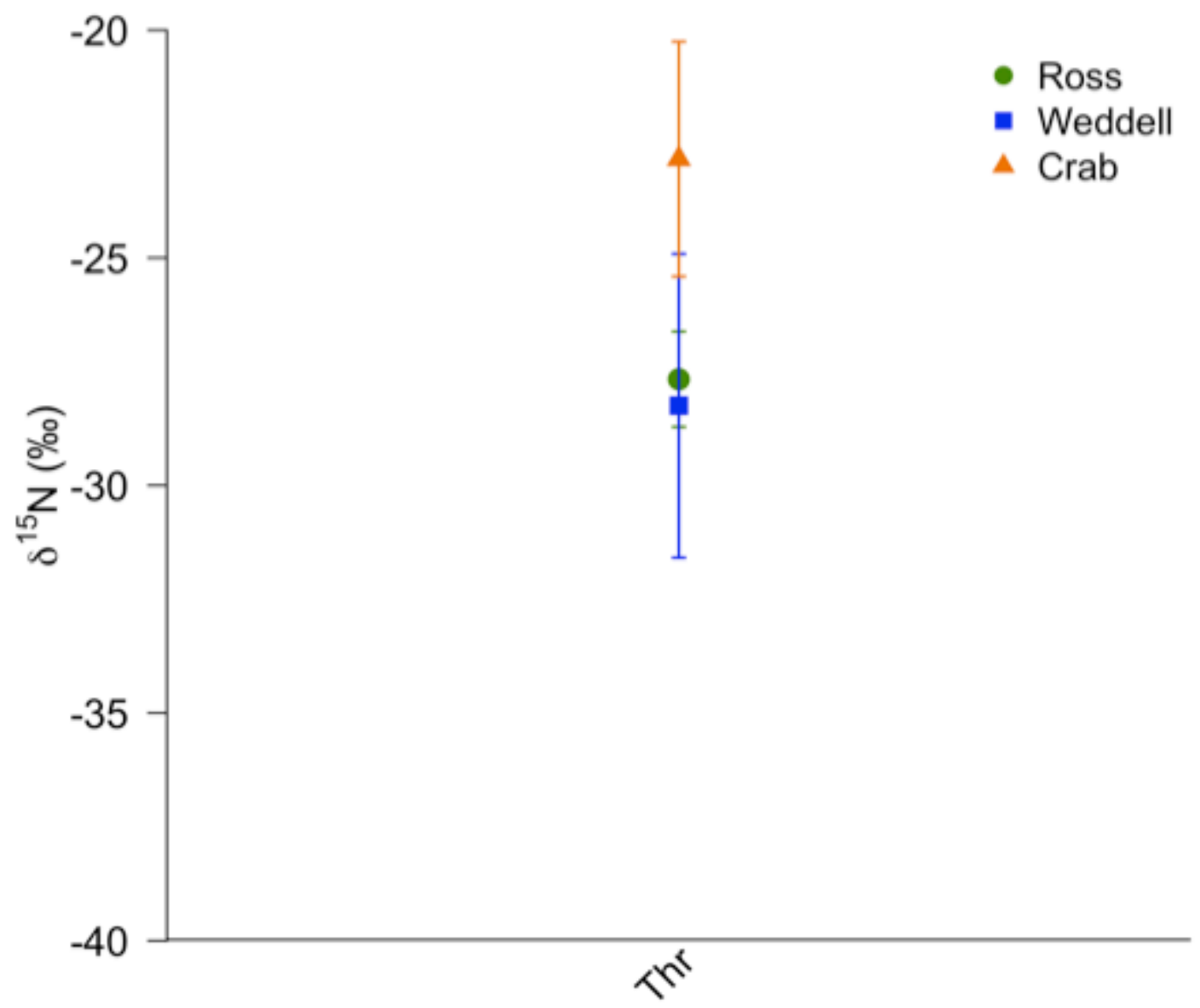

\section{Amino Acid}

98

99

100

101

102

103
Fig. S2. $\delta^{15} \mathrm{~N}$ values (mean \pm 1 standard deviation) of threonine for Ross, Weddell, and crabeater seals. Species are shown with colors: blue squares for Weddell seals, orange triangles for crabeater seals, and green circles for Ross seals. 
Antarctic Seal Foraging Ecology
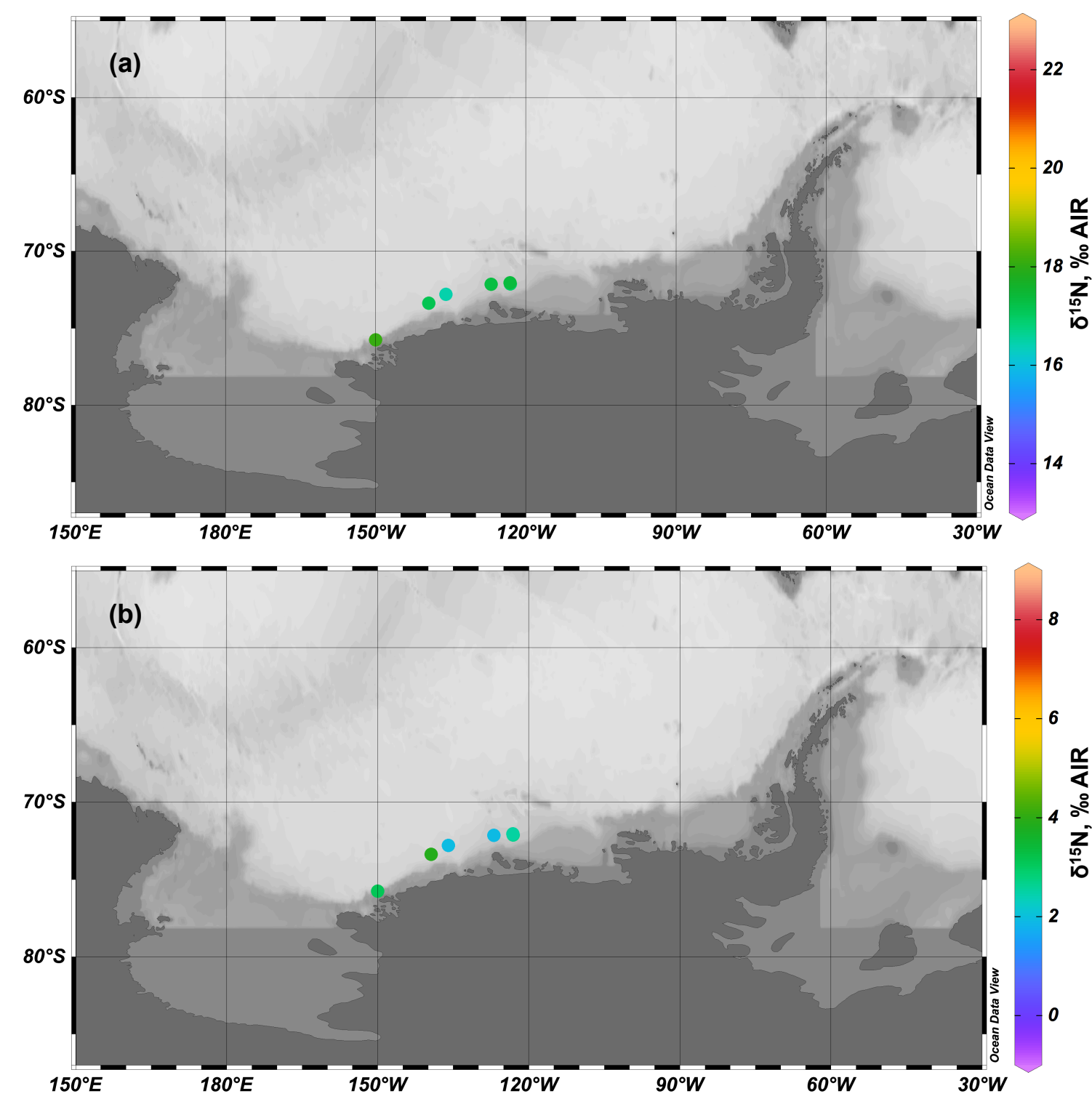

Fig. S3. Spatial variation in $\delta^{15} \mathrm{~N}$ values of Pro (a) and Phe (b) values for Ross seals. Figures were produced in Ocean Data View 4.7.4 (Schlitzer 2015). 
Antarctic Seal Foraging Ecology

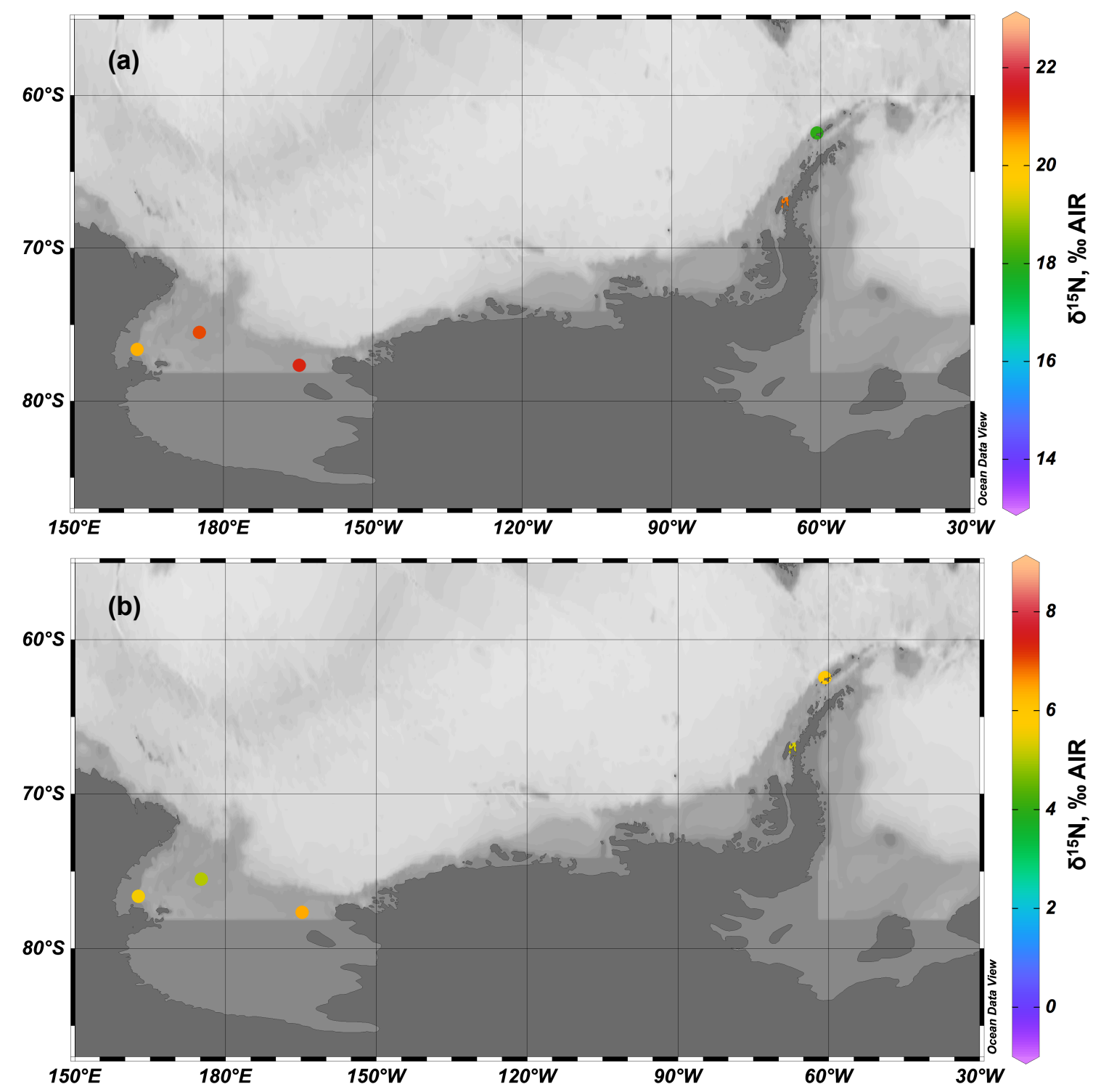

111 Fig. S4. Spatial variation in $\delta^{15} \mathrm{~N}$ values of Pro (a) and Phe (b) values for Weddell seals. Figures were 112 produced in Ocean Data View 4.7.4 (Schlitzer 2015).

113

114 
Antarctic Seal Foraging Ecology

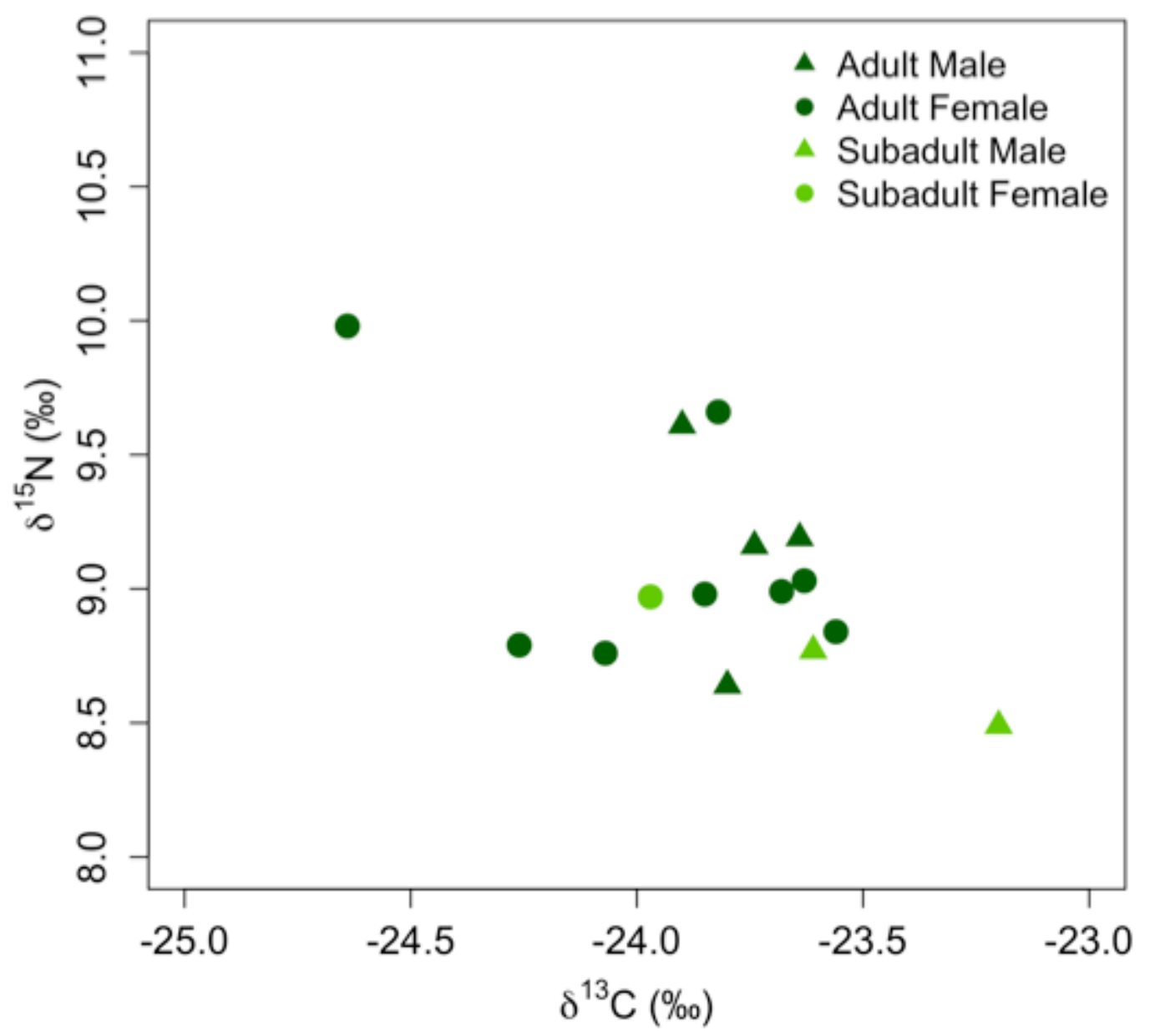

115

116

117

Fig. S5. Bulk $\delta^{13} \mathrm{C}$ and $\delta^{15} \mathrm{~N}$ for Ross Seals. Age class and gender are indicated with colors (light green for subadults and dark green for adults) and shapes (triangles and circles for males and females,

118 correspondingly).

119 
Antarctic Seal Foraging Ecology

120

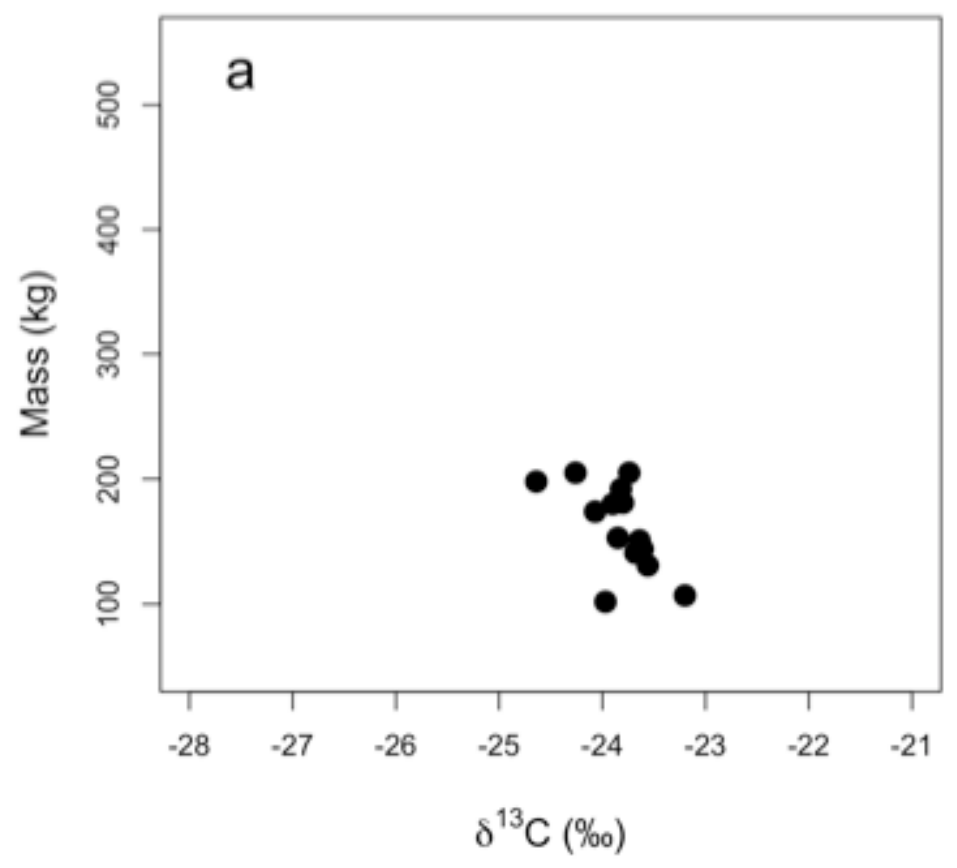

121

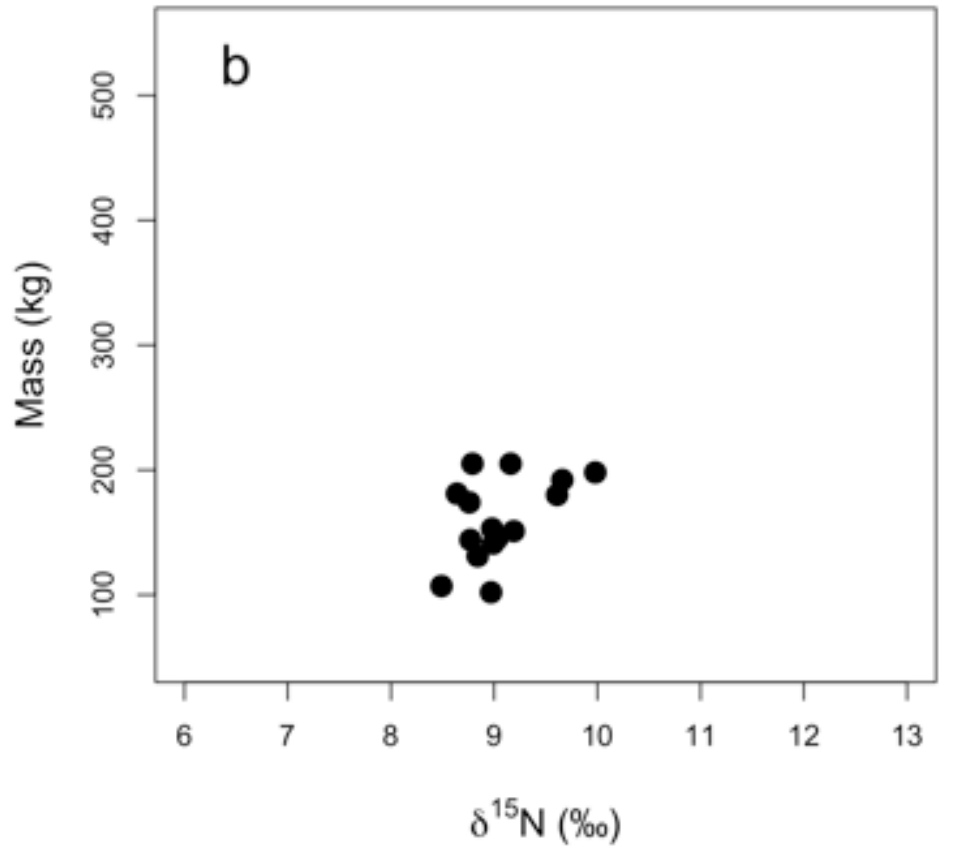

122 Fig. S6. Mass (kg) versus bulk $\delta^{13} \mathrm{C}(\mathrm{a})$ and $\delta^{15} \mathrm{~N}(\mathrm{~b})$ values for Ross 124 Seals.

125

126

127 


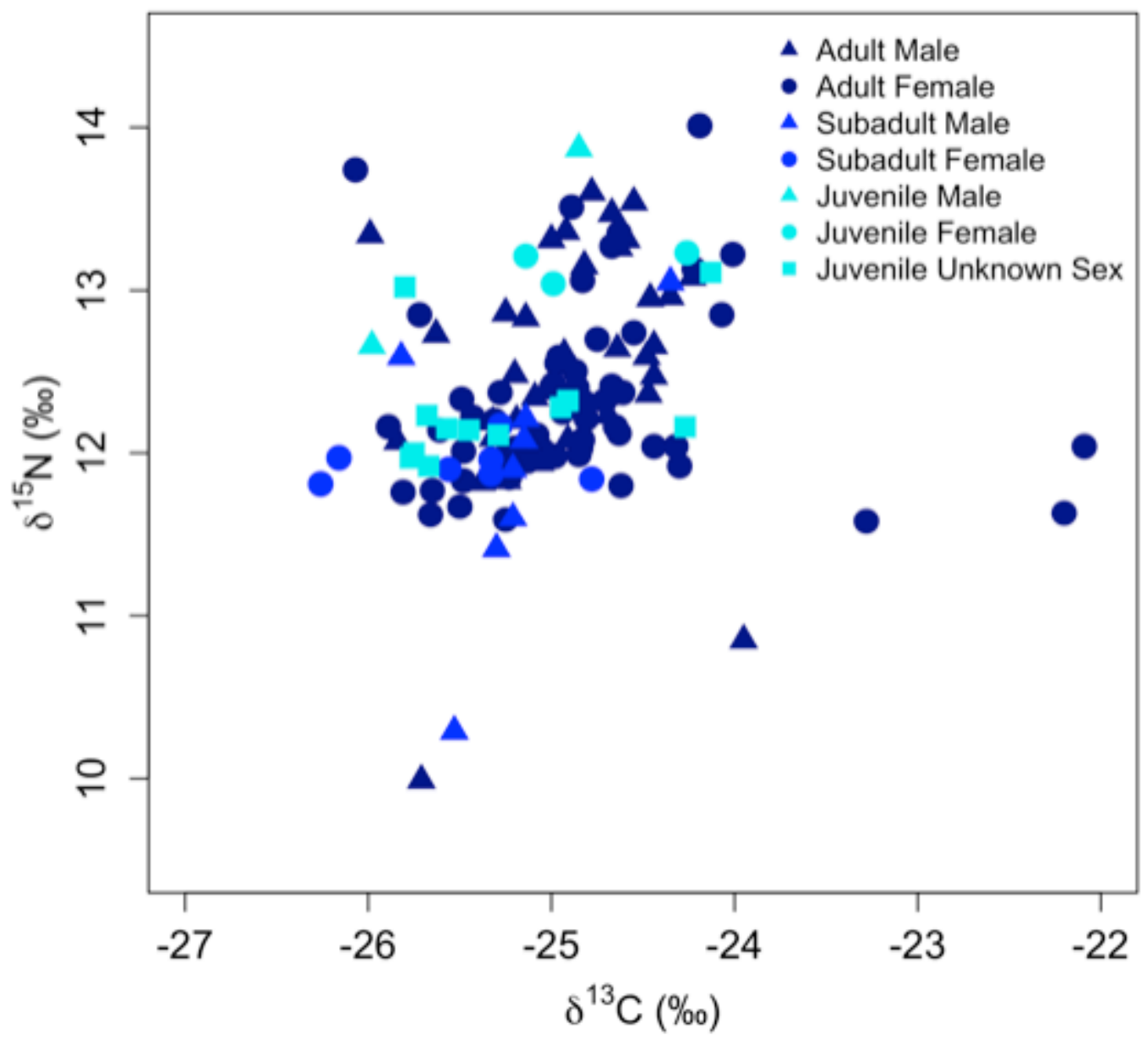

Fig. S7. Bulk $\delta^{13} \mathrm{C}$ and $\delta^{15} \mathrm{~N}$ for Weddell Seals. Age class and gender are indicated with colors (light blue for juveniles, medium blue for subadults, and dark blue for adults) and shapes (triangles, circles, and squares for males, females, and unknown sex, correspondingly). 
Antarctic Seal Foraging Ecology
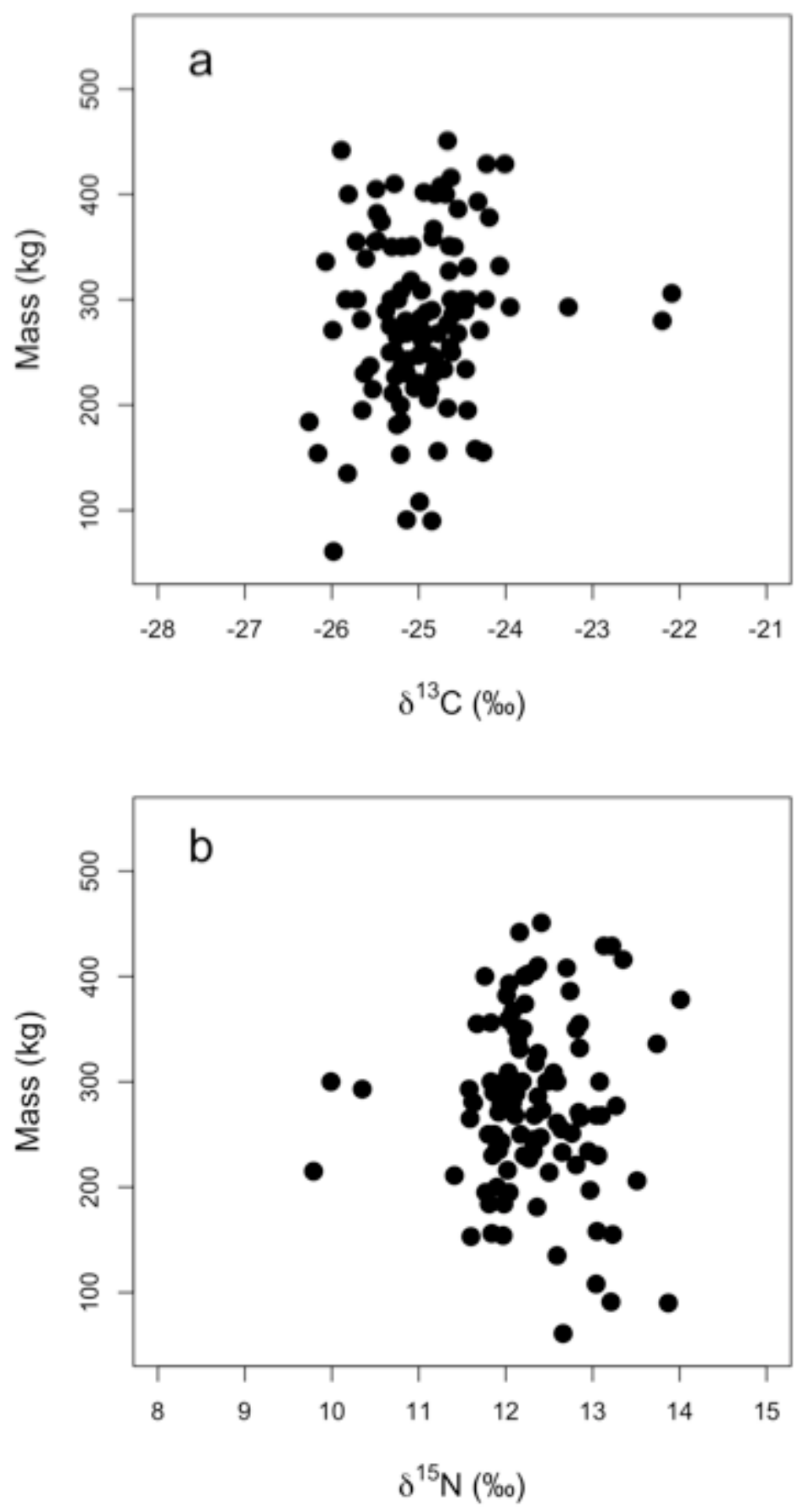

137

Fig. S8. Mass ( $\mathrm{kg}$ ) versus bulk $\delta^{13} \mathrm{C}(\mathrm{a})$ and $\delta^{15} \mathrm{~N}$ (b) values of Weddell Seals. 
Antarctic Seal Foraging Ecology

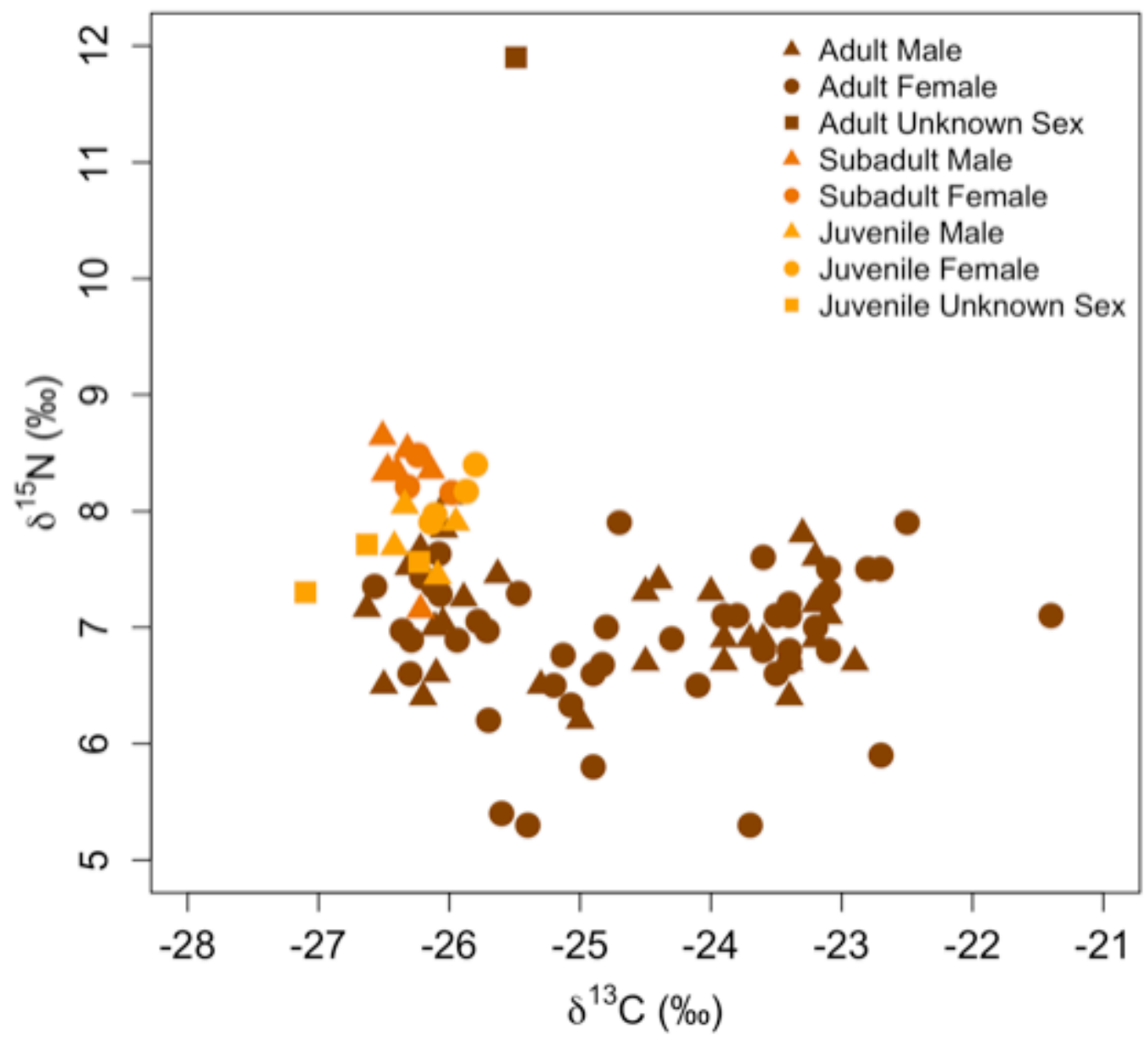

142

Fig. S9. Bulk $\delta^{13} \mathrm{C}$ and $\delta^{15} \mathrm{~N}$ for Crabeater Seals. Age class and gender are indicated with colors (light orange for juveniles, medium orange for subadults, and dark orange for adults) and shapes (triangles, circles, and squares for males, females, and unknown sex, correspondingly). 
Antarctic Seal Foraging Ecology

147

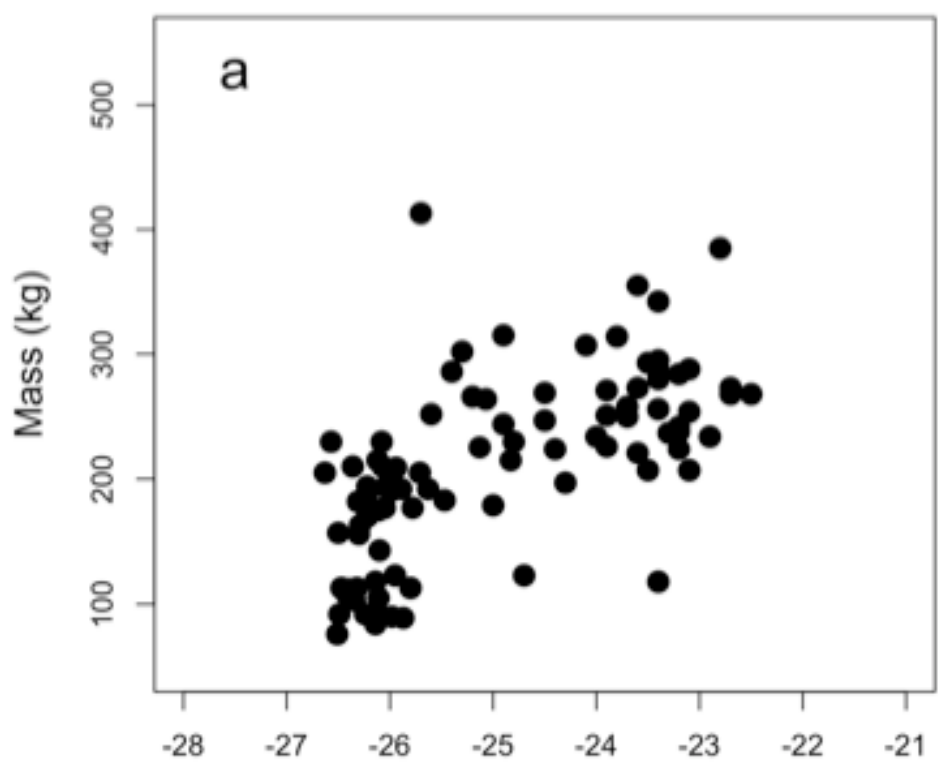

148

$\delta^{13} \mathrm{C}(\%)$

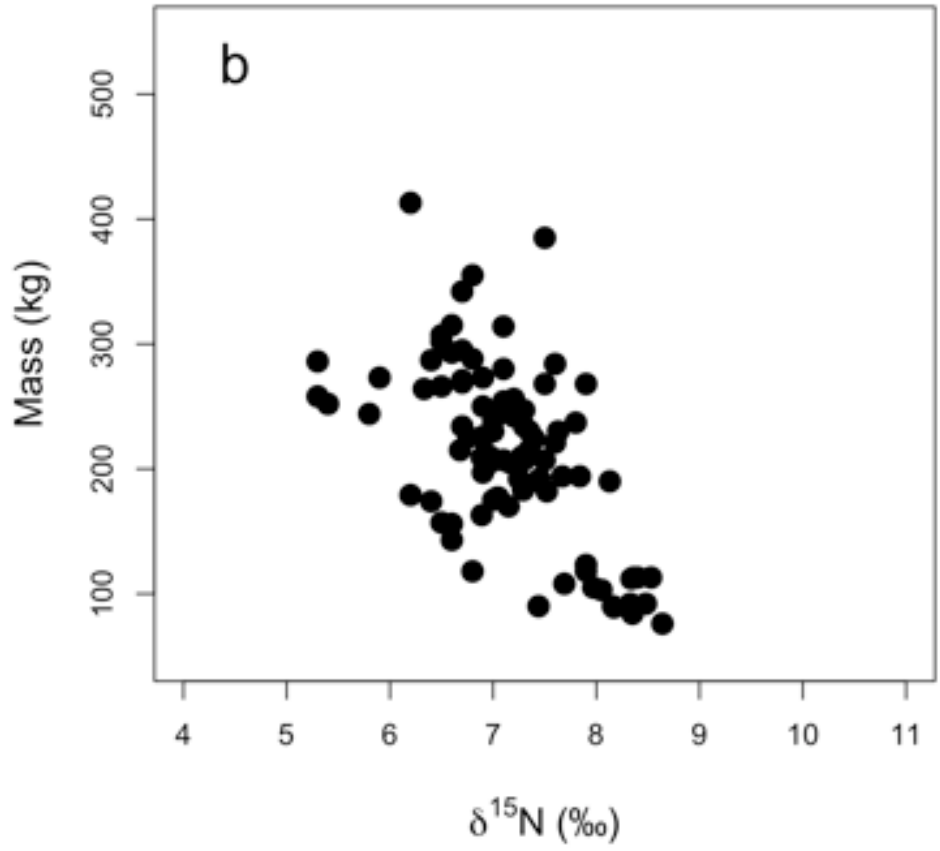

149

Fig. S10. Mass $(\mathrm{kg})$ versus bulk $\delta^{13} \mathrm{C}(\mathrm{a})$ and $\delta^{15} \mathrm{~N}(\mathrm{~b})$ values of 151 crabeater Seals.

152 


\section{Antarctic Seal Foraging Ecology}

153 Table S1. Sample information for Antarctic Seals. In cases where multiple sample types were obtained

154 from a seal, we indicate the tissue from which isotopic values were used in figures and statistical

155 analyses. Negative latitude and longitude indicate degrees south and west, respectively. Abbreviations:

156 DD, decimal degrees; WB, whole blood; RBCs, red blood cells; F, female; M, male; na, information not 157 available; Su, summer; Sp, spring; F, fall; W, winter; Oden, RV Oden cruises; MCM, McMurdo Station

158 region; WAP, West Antarctic Peninsula area; Ad, adult; Sub, subadult; Juv, juvenile; Lat, latitude; Long, 159 longitude.

\begin{tabular}{|c|c|c|c|c|c|c|c|c|c|}
\hline Species & $\begin{array}{c}\text { Sample } \\
\text { ID }\end{array}$ & Source & Season & $\begin{array}{c}\text { Sample } \\
\text { Type }\end{array}$ & $\begin{array}{c}\text { Age } \\
\text { Class }\end{array}$ & Sex & $\begin{array}{c}\text { Weight } \\
\text { (kg) }\end{array}$ & $\begin{array}{l}\text { Lat } \\
\text { (DD) }\end{array}$ & $\begin{array}{l}\text { Long } \\
\text { (DD) }\end{array}$ \\
\hline \multirow[t]{25}{*}{ Crabeater } & $\mathrm{C} 02$ & Oden & $\begin{array}{c}\mathrm{Su} \\
2010 / 11\end{array}$ & Clot & Ad & F & 163 & -68.6 & -102.3 \\
\hline & $\mathrm{C} 03$ & Oden & $\begin{array}{c}\mathrm{Su} \\
2008 / 09\end{array}$ & WB & Sub & F & na & -70.6 & -107.0 \\
\hline & $\mathrm{C} 03$ & Oden & $\begin{array}{c}\mathrm{Su} \\
2010 / 11\end{array}$ & Clot & Ad & $\mathrm{F}$ & 210 & -68.6 & -102.5 \\
\hline & $\mathrm{C} 04$ & Oden & $\begin{array}{c}\mathrm{Su} \\
2008 / 09\end{array}$ & WB & Sub & $\mathrm{M}$ & 92 & -70.6 & -107.0 \\
\hline & $\mathrm{C} 06$ & Oden & $\begin{array}{c}\mathrm{Su} \\
2008 / 09\end{array}$ & WB & Sub & $\mathrm{M}$ & 76 & -71.1 & -110.5 \\
\hline & $\mathrm{C} 07$ & Oden & $\begin{array}{c}\mathrm{Su} \\
2008 / 09\end{array}$ & WB & Sub & F & 92 & -71.1 & -110.5 \\
\hline & $\mathrm{C} 07$ & Oden & $\begin{array}{c}\mathrm{Su} \\
2010 / 11\end{array}$ & Hair & Ad & $\mathrm{F}$ & 205 & -69.5 & -103.7 \\
\hline & $\mathrm{C} 10$ & Oden & $\begin{array}{c}\mathrm{Su} \\
2010 / 11\end{array}$ & Hair & Ad & $\mathrm{F}$ & 225.4 & -69.5 & -103.7 \\
\hline & $\mathrm{C} 11$ & Oden & $\begin{array}{c}\mathrm{Su} \\
2010 / 11\end{array}$ & Hair & Ad & F & 264 & -69.5 & -103.7 \\
\hline & $\mathrm{C} 14$ & Oden & $\begin{array}{c}\mathrm{Su} \\
2010 / 11\end{array}$ & Clot & Ad & $\mathrm{F}$ & 215 & -70.1 & -107.4 \\
\hline & C15 & Oden & $\begin{array}{c}\mathrm{Su} \\
2010 / 11\end{array}$ & WB & Sub & $\mathrm{M}$ & 170 & -70.1 & -107.4 \\
\hline & $\mathrm{C} 20$ & Oden & $\begin{array}{c}\mathrm{Su} \\
2008 / 09\end{array}$ & WB & Ad & $\mathrm{M}$ & 190 & -72.6 & -116.0 \\
\hline & $\mathrm{C} 20$ & Oden & $\begin{array}{c}\mathrm{Su} \\
2010 / 11\end{array}$ & RBCs & Juv & $\mathrm{M}$ & 90 & -72.7 & -114.2 \\
\hline & $\mathrm{C} 21$ & Oden & $\begin{array}{c}\mathrm{Su} \\
2008 / 09\end{array}$ & Clot & Sub & $\mathrm{M}$ & 112 & -72.6 & -116.0 \\
\hline & $\mathrm{C} 21$ & Oden & $\begin{array}{c}\mathrm{Su} \\
2010 / 11\end{array}$ & RBCs & Juv & $\mathrm{M}$ & 103 & -72.7 & -114.2 \\
\hline & $\mathrm{C} 22$ & Oden & $\begin{array}{c}\mathrm{Su} \\
2008 / 09\end{array}$ & Clot & Sub & $\mathrm{M}$ & 113 & -72.6 & -116.0 \\
\hline & C32 & Oden & $\begin{array}{c}\mathrm{Su} \\
2008 / 09\end{array}$ & WB & Ad & $\mathrm{F}$ & 230 & -70.2 & -119.9 \\
\hline & C33 & Oden & $\begin{array}{c}\mathrm{Su} \\
2008 / 09\end{array}$ & WB & Ad & $\mathrm{M}$ & 194 & -70.2 & -119.9 \\
\hline & $\mathrm{C} 43$ & Oden & $\begin{array}{c}\mathrm{Su} \\
2008 / 09\end{array}$ & WB & $\mathrm{Ad}$ & $\mathrm{F}$ & 190 & -69.4 & -125.3 \\
\hline & C44 & Oden & $\begin{array}{c}\mathrm{Su} \\
2008 / 09\end{array}$ & WB & Ad & $\mathrm{M}$ & 182 & -69.4 & -125.3 \\
\hline & $\mathrm{C} 45$ & Oden & $\begin{array}{c}\mathrm{Su} \\
2008 / 09\end{array}$ & WB & $\mathrm{Ad}$ & $\mathrm{F}$ & 230 & -70.2 & -133.5 \\
\hline & $\mathrm{C} 46$ & Oden & $\begin{array}{c}\mathrm{Su} \\
2008 / 09\end{array}$ & WB & Sub & $\mathrm{F}$ & 90 & -72.5 & -146.5 \\
\hline & $\mathrm{C} 47$ & Oden & $\begin{array}{c}\mathrm{Su} \\
2008 / 09\end{array}$ & WB & Ad & $\mathrm{M}$ & 192 & -74.4 & -150.7 \\
\hline & $\mathrm{C} 48$ & Oden & $\begin{array}{c}\mathrm{Su} \\
2008 / 09\end{array}$ & WB & $\mathrm{Ad}$ & $\mathrm{F}$ & 177 & -74.4 & -150.7 \\
\hline & $\mathrm{C} 50$ & Oden & $\begin{array}{c}\mathrm{Su} \\
2008 / 09\end{array}$ & WB & Sub & $\mathrm{M}$ & 84 & -75.4 & -151.3 \\
\hline
\end{tabular}




\begin{tabular}{|c|c|c|c|c|c|c|c|c|}
\hline C51 & Oden & $\begin{array}{c}\mathrm{Su} \\
2008 / 09\end{array}$ & WB & $\mathrm{Ad}$ & $\mathrm{F}$ & 210 & -75.4 & -151.3 \\
\hline C52 & Oden & $\begin{array}{c}\mathrm{Su} \\
2008 / 09\end{array}$ & WB & Ad & $\mathrm{F}$ & 183 & -75.4 & -151.3 \\
\hline C143 & Oden & $\begin{array}{c}\mathrm{Su} \\
2010 / 11\end{array}$ & WB & Juv & $\mathrm{F}$ & 105 & -72.1 & -119.7 \\
\hline C144 & Oden & $\begin{array}{c}\mathrm{Su} \\
2010 / 11\end{array}$ & WB & Juv & $\mathrm{F}$ & 118 & -72.1 & -119.7 \\
\hline C153 & Oden & $\begin{array}{c}\mathrm{Su} \\
2010 / 11\end{array}$ & WB & Ad & M & 192 & -72.1 & -123.5 \\
\hline C154 & Oden & $\begin{array}{c}\mathrm{Su} \\
2010 / 11\end{array}$ & WB & $\mathrm{Ad}$ & M & 177 & -72.1 & -123.5 \\
\hline C155 & Oden & $\begin{array}{c}\mathrm{Su} \\
2010 / 11\end{array}$ & Hair & Juv & $\mathrm{M}$ & 108 & -72.2 & -126.7 \\
\hline C156 & Oden & $\begin{array}{c}\mathrm{Su} \\
2010 / 11\end{array}$ & WB & Juv & M & 123 & -72.2 & -126.7 \\
\hline C157 & Oden & $\begin{array}{c}\mathrm{Su} \\
2010 / 11\end{array}$ & WB & Juv & $\mathrm{F}$ & 113 & -72.2 & -126.7 \\
\hline C158 & Oden & $\begin{array}{c}\mathrm{Su} \\
2010 / 11\end{array}$ & WB & Juv & $\mathrm{F}$ & 89 & -72.2 & -126.7 \\
\hline $\mathrm{C} 173$ & Oden & $\begin{array}{c}\mathrm{Su} \\
2010 / 11\end{array}$ & WB & $\mathrm{Ad}$ & $\mathrm{F}$ & 209 & -72.8 & -135.6 \\
\hline C174 & Oden & $\begin{array}{c}\mathrm{Su} \\
2010 / 11\end{array}$ & WB & $\mathrm{Ad}$ & M & 175 & -75.3 & -139.5 \\
\hline C175 & Oden & $\begin{array}{c}\mathrm{Su} \\
2010 / 11\end{array}$ & Hair & Ad & $\mathrm{F}$ & 215 & -73.3 & -139.5 \\
\hline C176 & Oden & $\begin{array}{c}\mathrm{Su} \\
2010 / 11\end{array}$ & WB & Ad & M & 205 & -73.3 & -139.5 \\
\hline C177 & Oden & $\begin{array}{c}\mathrm{Su} \\
2010 / 11\end{array}$ & WB & Ad & M & 194 & -75.8 & -150.0 \\
\hline $\mathrm{Cr} 1$ & MCM & $\begin{array}{c}\mathrm{Su} \\
2009 / 10\end{array}$ & Hair & Juv & na & na & -77.6 & 166.2 \\
\hline $\begin{array}{c}\mathrm{Cr} \\
\text { Royds }\end{array}$ & MCM & $\begin{array}{c}\mathrm{Su} \\
2009 / 10\end{array}$ & Hair & Juv & na & na & -77.6 & 166.2 \\
\hline $\mathrm{Cr} 2$ & MCM & $\begin{array}{c}\mathrm{Su} \\
2009 / 10\end{array}$ & Hair & Juv & na & na & -77.6 & 166.2 \\
\hline $\begin{array}{c}\text { CS11- } \\
01\end{array}$ & MCM & $\begin{array}{c}\mathrm{Su} \\
2010 / 11\end{array}$ & WB & Ad & na & na & -77.7 & 166.5 \\
\hline G001 & $\begin{array}{l}\text { Hückstädt } \\
\text { et al. } \\
\text { (2012a) }\end{array}$ & F 2001 & Whisker & Ad & $\mathrm{F}$ & na & -67.3 & -67.6 \\
\hline G003 & $\begin{array}{l}\text { Hückstädt } \\
\text { et al. } \\
\text { (2012a) }\end{array}$ & F 2001 & Whisker & $\mathrm{Ad}$ & $\mathrm{F}$ & 258 & -67.3 & -67.6 \\
\hline G004 & $\begin{array}{l}\text { Hückstädt } \\
\text { et al. } \\
\text { (2012a) }\end{array}$ & F 2001 & Whisker & Ad & M & 342 & -69.2 & -72.3 \\
\hline G005 & $\begin{array}{l}\text { Hückstädt } \\
\text { et al. } \\
\text { (2012a) }\end{array}$ & F 2001 & Whisker & Ad & $\mathrm{F}$ & 293 & -69.3 & -72.4 \\
\hline G006 & $\begin{array}{l}\text { Hückstädt } \\
\text { et al. } \\
\text { (2012a) }\end{array}$ & F 2001 & Whisker & Ad & $\mathrm{F}$ & 413 & -69.3 & -72.5 \\
\hline G007 & $\begin{array}{l}\text { Hückstädt } \\
\text { et al. } \\
\text { (2012a) }\end{array}$ & F 2001 & Whisker & $\mathrm{Ad}$ & M & 287 & -69.3 & -72.5 \\
\hline
\end{tabular}




\begin{tabular}{|c|c|c|c|c|c|c|c|c|}
\hline G008 & $\begin{array}{l}\text { Hückstädt } \\
\text { et al. } \\
\text { (2012a) }\end{array}$ & F 2001 & Whisker & $\mathrm{Ad}$ & $\mathrm{F}$ & 355 & -69.1 & -72.4 \\
\hline G009 & $\begin{array}{l}\text { Hückstädt } \\
\text { et al. } \\
\text { (2012a) }\end{array}$ & W 2001 & Whisker & Ad & $\mathrm{M}$ & 179 & -67.7 & -69.3 \\
\hline G010 & $\begin{array}{l}\text { Hückstädt } \\
\text { et al. } \\
\text { (2012a) }\end{array}$ & W 2001 & Whisker & $\mathrm{Ad}$ & $\mathrm{F}$ & 307 & -68.1 & -70.4 \\
\hline G012 & $\begin{array}{l}\text { Hückstädt } \\
\text { et al. } \\
\text { (2012a) }\end{array}$ & W 2001 & Whisker & Ad & $\mathrm{F}$ & 288 & -68.1 & -70.2 \\
\hline G013 & $\begin{array}{l}\text { Hückstädt } \\
\text { et al. } \\
\text { (2012a) }\end{array}$ & W 2001 & Whisker & $\mathrm{Ad}$ & $\mathrm{M}$ & 234 & -68.1 & -70.2 \\
\hline G014 & $\begin{array}{l}\text { Hückstädt } \\
\text { et al. } \\
\text { (2012a) }\end{array}$ & W 2001 & Whisker & $\mathrm{Ad}$ & $\mathrm{M}$ & 284 & -68.1 & -70.1 \\
\hline G015 & $\begin{array}{l}\text { Hückstädt } \\
\text { et al. } \\
\text { (2012a) }\end{array}$ & W 2001 & Whisker & $\mathrm{Ad}$ & M & 234 & -67.2 & -70.2 \\
\hline G016 & $\begin{array}{l}\text { Hückstädt } \\
\text { et al. } \\
\text { (2012a) }\end{array}$ & W 2001 & Whisker & $\mathrm{Ad}$ & $\mathrm{F}$ & 273 & -67.4 & -70.9 \\
\hline G017 & $\begin{array}{l}\text { Hückstädt } \\
\text { et al. } \\
\text { (2012a) }\end{array}$ & F 2002 & Whisker & $\mathrm{Ad}$ & $\mathrm{F}$ & 118 & -66.4 & -66.8 \\
\hline G018 & $\begin{array}{l}\text { Hückstädt } \\
\text { et al. } \\
\text { (2012a) }\end{array}$ & F 2002 & Whisker & $\mathrm{Ad}$ & $\mathrm{M}$ & 157 & -66.8 & -66.8 \\
\hline G019 & $\begin{array}{l}\text { Hückstädt } \\
\text { et al. } \\
\text { (2012a) }\end{array}$ & F 2002 & Whisker & $\mathrm{Ad}$ & $\mathrm{F}$ & 156 & -66.8 & -66.8 \\
\hline G020 & $\begin{array}{l}\text { Hückstädt } \\
\text { et al. } \\
\text { (2012a) }\end{array}$ & F 2002 & Whisker & $\mathrm{Ad}$ & $\mathrm{M}$ & 143 & -66.6 & -67.5 \\
\hline G021 & $\begin{array}{c}\text { Hückstädt } \\
\text { et al. } \\
\text { (2012a) }\end{array}$ & F 2002 & Whisker & $\mathrm{Ad}$ & $\mathrm{M}$ & 271 & -66.6 & -67.5 \\
\hline G022 & $\begin{array}{l}\text { Hückstädt } \\
\text { et al. } \\
\text { (2012a) }\end{array}$ & F 2002 & Whisker & $\mathrm{Ad}$ & $\mathrm{F}$ & 268 & -67.4 & -67.7 \\
\hline G023 & $\begin{array}{l}\text { Hückstädt } \\
\text { et al. } \\
\text { (2012a) }\end{array}$ & F 2002 & Whisker & $\mathrm{Ad}$ & $\mathrm{M}$ & 174 & -67.6 & -68.2 \\
\hline G024 & $\begin{array}{l}\text { Hückstädt } \\
\text { et al. } \\
\text { (2012a) }\end{array}$ & F 2002 & Whisker & $\mathrm{Ad}$ & $\mathrm{F}$ & 256 & -67.6 & -69.0 \\
\hline G026 & $\begin{array}{l}\text { Hückstädt } \\
\text { et al. } \\
\text { (2012a) }\end{array}$ & F 2002 & Whisker & $\mathrm{Ad}$ & $\mathrm{F}$ & 266 & -67.6 & -69.0 \\
\hline G027 & $\begin{array}{l}\text { Hückstädt } \\
\text { et al. } \\
\text { (2012a) }\end{array}$ & F 2002 & Whisker & $\mathrm{Ad}$ & $\mathrm{M}$ & 226 & -66.6 & -67.5 \\
\hline
\end{tabular}




\begin{tabular}{|c|c|c|c|c|c|c|c|c|}
\hline G028 & $\begin{array}{l}\text { Hückstädt } \\
\text { et al. } \\
\text { (2012a) }\end{array}$ & F 2002 & Whisker & Ad & $\mathrm{F}$ & 314 & -68.5 & -69.8 \\
\hline G029 & $\begin{array}{l}\text { Hückstädt } \\
\text { et al. } \\
\text { (2012a) }\end{array}$ & F 2002 & Whisker & $\mathrm{Ad}$ & $\mathrm{M}$ & 242 & -68.7 & -70.0 \\
\hline G030 & $\begin{array}{l}\text { Hückstädt } \\
\text { et al. } \\
\text { (2012a) }\end{array}$ & F 2002 & Whisker & Ad & $\mathrm{M}$ & 250 & -66.6 & -67.5 \\
\hline G031 & $\begin{array}{l}\text { Hückstädt } \\
\text { et al. } \\
\text { (2012a) }\end{array}$ & F 2002 & Whisker & $\mathrm{Ad}$ & $\mathrm{F}$ & 385 & -66.3 & -66.6 \\
\hline G032 & $\begin{array}{l}\text { Hückstädt } \\
\text { et al. } \\
\text { (2012a) }\end{array}$ & F 2002 & Whisker & $\mathrm{Ad}$ & $\mathrm{F}$ & 230 & -68.8 & -69.9 \\
\hline G033 & $\begin{array}{l}\text { Hückstädt } \\
\text { et al. } \\
\text { (2012a) }\end{array}$ & W 2002 & Whisker & Ad & $\mathrm{F}$ & 268 & -66.3 & -66.7 \\
\hline G034 & $\begin{array}{l}\text { Hückstädt } \\
\text { et al. } \\
\text { (2012a) }\end{array}$ & W 2002 & Whisker & Ad & $\mathrm{F}$ & 295 & -66.5 & -67.1 \\
\hline G035 & $\begin{array}{l}\text { Hückstädt } \\
\text { et al. } \\
\text { (2012a) }\end{array}$ & W 2002 & Whisker & Ad & $\mathrm{F}$ & 238 & -66.4 & -66.9 \\
\hline G036 & $\begin{array}{l}\text { Hückstädt } \\
\text { et al. } \\
\text { (2012a) }\end{array}$ & W 2002 & Whisker & Ad & $\mathrm{F}$ & 207 & -66.4 & -66.9 \\
\hline G038 & $\begin{array}{l}\text { Hückstädt } \\
\text { et al. } \\
\text { (2012a) }\end{array}$ & W 2002 & Whisker & Ad & $\mathrm{M}$ & 273 & -67.2 & -70.6 \\
\hline G039 & $\begin{array}{l}\text { Hückstädt } \\
\text { et al. } \\
\text { (2012a) }\end{array}$ & W 2002 & Whisker & Ad & M & 247 & -68.6 & -76.0 \\
\hline G040 & $\begin{array}{l}\text { Hückstädt } \\
\text { et al. } \\
\text { (2012a) }\end{array}$ & W 2002 & Whisker & $\mathrm{Ad}$ & $\mathrm{M}$ & 302 & -68.5 & -75.8 \\
\hline G041 & $\begin{array}{l}\text { Hückstädt } \\
\text { et al. } \\
\text { (2012a) }\end{array}$ & W 2002 & Whisker & $\mathrm{Ad}$ & $\mathrm{M}$ & 269 & -68.1 & -75.0 \\
\hline G042 & $\begin{array}{c}\text { Hückstädt } \\
\text { et al. } \\
\text { (2012a) }\end{array}$ & W 2002 & Whisker & Ad & $\mathrm{M}$ & 224 & -68.0 & -74.9 \\
\hline G043 & $\begin{array}{l}\text { Hückstädt } \\
\text { et al. } \\
(2012 \mathrm{a})\end{array}$ & W 2002 & Whisker & $\mathrm{Ad}$ & $\mathrm{M}$ & 224 & -68.0 & -74.8 \\
\hline G044 & $\begin{array}{l}\text { Hückstädt } \\
\text { et al. } \\
\text { (2012a) }\end{array}$ & W 2002 & Whisker & $\mathrm{Ad}$ & $\mathrm{F}$ & 280 & -65.7 & -68.7 \\
\hline G045 & $\begin{array}{l}\text { Hückstädt } \\
\text { et al. } \\
\text { (2012a) }\end{array}$ & W 2002 & Whisker & Ad & $\mathrm{F}$ & 221 & -65.6 & -68.6 \\
\hline G046 & $\begin{array}{l}\text { Hückstädt } \\
\text { et al. } \\
\text { (2012a) }\end{array}$ & W 2002 & Whisker & $\mathrm{Ad}$ & $\mathrm{M}$ & 237 & -65.5 & -68.5 \\
\hline
\end{tabular}




\begin{tabular}{|c|c|c|c|c|c|c|c|c|c|}
\hline & G047 & $\begin{array}{l}\text { Hückstädt } \\
\text { et al. } \\
(2012 \mathrm{a})\end{array}$ & W 2002 & Whisker & Ad & $\mathrm{M}$ & 254 & -65.7 & -68.5 \\
\hline & G102 & $\begin{array}{l}\text { Hückstädt } \\
\text { et al. } \\
(2012 \mathrm{a})\end{array}$ & F 2007 & Whisker & Ad & $\mathrm{F}$ & 286 & -67.2 & -66.9 \\
\hline & G104 & $\begin{array}{l}\text { Hückstädt } \\
\text { et al. } \\
(2012 \mathrm{a})\end{array}$ & F 2007 & Whisker & Ad & $\mathrm{F}$ & 197 & -67.2 & -66.9 \\
\hline & G105 & $\begin{array}{l}\text { Hückstädt } \\
\text { et al. } \\
(2012 \mathrm{a})\end{array}$ & F 2007 & Whisker & Ad & $\mathrm{F}$ & 251 & -67.2 & -66.8 \\
\hline & G106 & $\begin{array}{c}\text { Hückstädt } \\
\text { et al. } \\
(2012 \mathrm{a})\end{array}$ & F 2007 & Whisker & $\mathrm{Ad}$ & $\mathrm{F}$ & 207 & -67.2 & -66.8 \\
\hline & G107 & $\begin{array}{l}\text { Hückstädt } \\
\text { et al. } \\
(2012 \mathrm{a})\end{array}$ & F 2007 & Whisker & $\mathrm{Ad}$ & $\mathrm{F}$ & 315 & -67.0 & -67.4 \\
\hline & G108 & $\begin{array}{l}\text { Hückstädt } \\
\text { et al. } \\
(2012 \mathrm{a})\end{array}$ & F 2007 & Whisker & Ad & $\mathrm{F}$ & 207 & -67.2 & -66.8 \\
\hline & G110 & $\begin{array}{l}\text { Hückstädt } \\
\text { et al. } \\
(2012 \mathrm{a})\end{array}$ & F 2007 & Whisker & Ad & $\mathrm{F}$ & 123 & -67.1 & -66.8 \\
\hline & G112 & $\begin{array}{l}\text { Hückstädt } \\
\text { et al. }\end{array}$ & F 2007 & Whisker & $\mathrm{Ad}$ & $\mathrm{F}$ & 252 & -65.2 & -64.2 \\
\hline & G113 & $\begin{array}{l}(2012 \mathrm{a}) \\
\text { Hückstädt } \\
\text { et al. } \\
(2012 \mathrm{a})\end{array}$ & F 2007 & Whisker & Ad & $\mathrm{F}$ & 244 & -66.1 & -65.4 \\
\hline & W02 & Oden & $\begin{array}{c}\mathrm{Su} \\
2008 / 09 \\
\end{array}$ & WB & Sub & $\mathrm{M}$ & 113 & -71.7 & -112.2 \\
\hline Weddell & W01 & Oden & $\begin{array}{c}\mathrm{Su} \\
2010 / 11\end{array}$ & Hair & Ad & M & 251 & -72.6 & -115.1 \\
\hline & W02 & Oden & $\begin{array}{c}\mathrm{Su} \\
2010 / 11\end{array}$ & Hair & Ad & $\mathrm{F}$ & 300 & -72.6 & -115.1 \\
\hline & W04 & Oden & $\begin{array}{c}\mathrm{Su} \\
2010 / 11\end{array}$ & Clot & Ad & $\mathrm{F}$ & 400 & -72.8 & -114.4 \\
\hline & W06 & Oden & $\begin{array}{c}\mathrm{Su} \\
2010 / 11\end{array}$ & Clot & $\mathrm{Ad}$ & $\mathrm{M}$ & 400 & -72.9 & -114.2 \\
\hline & W10 & Oden & $\begin{array}{c}\mathrm{Su} \\
2008 / 09\end{array}$ & WB & Sub & $\mathrm{F}$ & 156 & -77.3 & -165.5 \\
\hline & W11 & Oden & $\begin{array}{c}\mathrm{Su} \\
2008 / 09\end{array}$ & WB & Sub & $\mathrm{M}$ & 153 & -77.3 & -165.5 \\
\hline & W12 & Oden & $\begin{array}{c}\mathrm{Su} \\
2008 / 09\end{array}$ & WB & Ad & M & 318 & -77.3 & -165.5 \\
\hline & W14 & Oden & $\begin{array}{c}\mathrm{Su} \\
2008 / 09\end{array}$ & WB & Ad & M & 288 & -77.3 & -165.5 \\
\hline & W15 & Oden & $\begin{array}{c}\mathrm{Su} \\
2008 / 09\end{array}$ & WB & Sub & $\mathrm{M}$ & 211 & -77.3 & -165.5 \\
\hline & W17 & Oden & $\begin{array}{c}\mathrm{Su} \\
2008 / 09\end{array}$ & WB & Ad & $\mathrm{M}$ & 278 & -77.3 & -165.5 \\
\hline & W19 & Oden & $\begin{array}{c}\mathrm{Su} \\
2008 / 09\end{array}$ & WB & Ad & $\mathrm{F}$ & 309 & -77.3 & -165.5 \\
\hline & W103 & Oden & $\begin{array}{c}\mathrm{Su} \\
2010 / 11\end{array}$ & WB & Ad & $\mathrm{M}$ & 300 & -72.6 & -115.1 \\
\hline
\end{tabular}


Antarctic Seal Foraging Ecology

\begin{tabular}{|c|c|c|c|c|c|c|c|c|}
\hline W112 & Oden & $\begin{array}{c}\mathrm{Su} \\
2010 / 11\end{array}$ & Hair & $\mathrm{Ad}$ & M & 350 & -72.9 & -114.0 \\
\hline W113 & Oden & $\begin{array}{c}\mathrm{Su} \\
2010 / 11\end{array}$ & WB & Ad & $\mathrm{M}$ & 255 & -72.9 & -114.0 \\
\hline W116 & Oden & $\begin{array}{c}\mathrm{Su} \\
2010 / 11\end{array}$ & WB & $\mathrm{Ad}$ & M & 300 & -71.7 & -115.5 \\
\hline W117 & Oden & $\begin{array}{c}\mathrm{Su} \\
2010 / 11\end{array}$ & WB & Ad & $\mathrm{F}$ & 290 & -71.7 & -115.5 \\
\hline W118 & Oden & $\begin{array}{c}\mathrm{Su} \\
2010 / 11\end{array}$ & WB & Ad & $\mathrm{F}$ & 216 & -71.7 & -115.5 \\
\hline W130 & Oden & $\begin{array}{c}\mathrm{Su} \\
2010 / 11\end{array}$ & WB & Sub & M & 158 & -72.5 & -116.6 \\
\hline W133 & Oden & $\begin{array}{c}\mathrm{Su} \\
2010 / 11\end{array}$ & WB & $\mathrm{Ad}$ & M & 300 & -72.5 & -116.6 \\
\hline W136 & Oden & $\begin{array}{c}\mathrm{Su} \\
2010 / 11\end{array}$ & WB & Ad & $\mathrm{F}$ & 235 & -72.9 & -116.9 \\
\hline W137 & Oden & $\begin{array}{c}\mathrm{Su} \\
2010 / 11\end{array}$ & WB & $\mathrm{Ad}$ & $\mathrm{F}$ & 243 & -72.9 & -116.9 \\
\hline W155 & Oden & $\begin{array}{c}\mathrm{Su} \\
2010 / 11\end{array}$ & WB & Juv & $\mathrm{F}$ & 155 & -72.1 & -119.2 \\
\hline W157 & Oden & $\begin{array}{c}\mathrm{Su} \\
2010 / 11\end{array}$ & WB & Juv & $\mathrm{F}$ & 108 & -72.1 & -119.2 \\
\hline W174 & Oden & $\begin{array}{c}\mathrm{Su} \\
2010 / 11\end{array}$ & WB & $\mathrm{Ad}$ & $\mathrm{F}$ & 250 & -72.1 & -119.7 \\
\hline W175 & Oden & $\begin{array}{c}\mathrm{Su} \\
2010 / 11\end{array}$ & WB & $\mathrm{Ad}$ & M & 300 & -72.1 & -119.7 \\
\hline W176 & Oden & $\begin{array}{c}\mathrm{Su} \\
2010 / 11\end{array}$ & WB & $\mathrm{Ad}$ & M & na & -72.1 & -119.7 \\
\hline W177 & Oden & $\begin{array}{c}\mathrm{Su} \\
2010 / 11\end{array}$ & WB & $\mathrm{Ad}$ & M & 234 & -72.1 & -119.7 \\
\hline W182 & Oden & $\begin{array}{c}\mathrm{Su} \\
2010 / 11\end{array}$ & Hair & Sub & $\mathrm{M}$ & 215 & -72.8 & -135.8 \\
\hline W185 & Oden & $\begin{array}{c}\mathrm{Su} \\
2010 / 11\end{array}$ & WB & $\mathrm{Ad}$ & $\mathrm{F}$ & 400 & -75.5 & -184.9 \\
\hline W186 & Oden & $\begin{array}{c}\mathrm{Su} \\
2010 / 11\end{array}$ & WB & Sub & $\mathrm{F}$ & 154 & -75.5 & -184.9 \\
\hline W208 & Oden & $\begin{array}{c}\mathrm{Su} \\
2010 / 11\end{array}$ & WB & Sub & M & 135 & -78.7 & -164.2 \\
\hline W209 & Oden & $\begin{array}{c}\mathrm{Su} \\
2010 / 11\end{array}$ & WB & Juv & M & 61 & -78.7 & -164.2 \\
\hline W214 & Oden & $\begin{array}{c}\mathrm{Su} \\
2010 / 11\end{array}$ & WB & Sub & $\mathrm{F}$ & 184 & -77.6 & -166.3 \\
\hline W216 & Oden & $\begin{array}{c}\mathrm{Su} \\
2010 / 11\end{array}$ & WB & Juv & $\mathrm{F}$ & 91 & -77.6 & -166.3 \\
\hline W219 & Oden & $\begin{array}{c}\mathrm{Su} \\
2010 / 11\end{array}$ & WB & Sub & $\mathrm{F}$ & 237 & -77.7 & -164.7 \\
\hline W220 & Oden & $\begin{array}{c}\mathrm{Su} \\
2010 / 11\end{array}$ & WB & Ad & $\mathrm{F}$ & 261 & -77.7 & -164.7 \\
\hline W222 & Oden & $\begin{array}{c}\mathrm{Su} \\
2010 / 11\end{array}$ & WB & $\mathrm{Ad}$ & $\mathrm{M}$ & 350 & -77.7 & -164.7 \\
\hline W223 & Oden & $\begin{array}{c}\mathrm{Su} \\
2010 / 11\end{array}$ & WB & Juv & M & 90 & -77.7 & -164.7 \\
\hline $\begin{array}{c}\text { WS10- } \\
11\end{array}$ & MCM & $\begin{array}{c}\mathrm{Su} \\
2009 / 10\end{array}$ & RBCs & $\mathrm{Ad}$ & $\mathrm{F}$ & 308.5 & -75.8 & 162.8 \\
\hline $\begin{array}{c}\text { WS10- } \\
12\end{array}$ & MCM & $\begin{array}{c}\mathrm{Su} \\
2009 / 10\end{array}$ & RBCs & $\mathrm{Ad}$ & $\mathrm{F}$ & 282.5 & -75.8 & 162.8 \\
\hline $\begin{array}{c}\text { WS10- } \\
13\end{array}$ & MCM & $\begin{array}{c}\mathrm{Su} \\
2009 / 10\end{array}$ & RBCs & $\mathrm{Ad}$ & $\mathrm{F}$ & 245 & -75.8 & 162.8 \\
\hline
\end{tabular}




\begin{tabular}{|c|c|c|c|c|c|c|c|c|}
\hline $\begin{array}{c}\text { WS10- } \\
17\end{array}$ & $\mathrm{MCM}$ & $\begin{array}{c}\mathrm{Su} \\
2009 / 10\end{array}$ & RBCs & $\mathrm{Ad}$ & F & 356 & -76.5 & 162.8 \\
\hline $\begin{array}{c}\text { WS10- } \\
18\end{array}$ & MCM & $\begin{array}{c}\mathrm{Su} \\
2009 / 10\end{array}$ & RBCs & $\mathrm{Ad}$ & F & 265 & -76.5 & 162.8 \\
\hline $\begin{array}{c}\text { WS11- } \\
11\end{array}$ & MCM & $\begin{array}{c}\mathrm{Su} \\
2010 / 11\end{array}$ & WB & $\mathrm{Ad}$ & F & 281 & -76.6 & 162.7 \\
\hline $\begin{array}{c}\text { WS11- } \\
12\end{array}$ & MCM & $\begin{array}{c}\mathrm{Su} \\
2010 / 11\end{array}$ & WB & $\mathrm{Ad}$ & F & 355 & -77.9 & 166.8 \\
\hline $\begin{array}{c}\text { WS11- } \\
13\end{array}$ & MCM & $\begin{array}{c}\mathrm{Su} \\
2010 / 11\end{array}$ & WB & $\mathrm{Ad}$ & F & 247 & -76.9 & 162.5 \\
\hline $\begin{array}{c}\text { WS11- } \\
14\end{array}$ & MCM & $\begin{array}{c}\mathrm{Su} \\
2010 / 11\end{array}$ & WB & Ad & F & 286 & -76.6 & 162.7 \\
\hline $\begin{array}{c}\text { WS11- } \\
15\end{array}$ & MCM & $\begin{array}{c}\mathrm{Su} \\
2010 / 11\end{array}$ & WB & Ad & F & 195 & -77.2 & 163.5 \\
\hline $\begin{array}{c}\text { WS12- } \\
11\end{array}$ & MCM & $\begin{array}{c}\mathrm{Su} \\
2011 / 12\end{array}$ & RBCs & Ad & $\mathrm{F}$ & 273 & -76.9 & 162.8 \\
\hline $\begin{array}{c}\text { WS12- } \\
12\end{array}$ & MCM & $\begin{array}{c}\mathrm{Su} \\
2011 / 12\end{array}$ & RBCs & Ad & $\mathrm{F}$ & 374 & -77.9 & 166.8 \\
\hline $\begin{array}{c}\text { WS12- } \\
13\end{array}$ & MCM & $\begin{array}{c}\mathrm{Su} \\
2011 / 12\end{array}$ & RBCs & $\mathrm{Ad}$ & $\mathrm{F}$ & 410 & -77.9 & 166.8 \\
\hline $\begin{array}{c}\text { WS12- } \\
14\end{array}$ & MCM & $\begin{array}{c}\mathrm{Su} \\
2011 / 12\end{array}$ & RBCs & $\mathrm{Ad}$ & M & 227 & -76.1 & 162.4 \\
\hline $\begin{array}{c}\text { WS12- } \\
15\end{array}$ & MCM & $\begin{array}{c}\mathrm{Su} \\
2011 / 12\end{array}$ & RBCs & $\mathrm{Ad}$ & M & 289 & -76.5 & 162.7 \\
\hline $\begin{array}{c}\text { WS12- } \\
22\end{array}$ & MCM & $\begin{array}{c}\mathrm{Sp} \\
2012\end{array}$ & WB & $\mathrm{Ad}$ & $\mathrm{F}$ & 451 & -77.7 & 166.5 \\
\hline $\begin{array}{c}\text { WS12- } \\
23\end{array}$ & MCM & $\begin{array}{c}\mathrm{Sp} \\
2012\end{array}$ & WB & $\mathrm{Ad}$ & $\mathrm{F}$ & 442 & -77.7 & 166.9 \\
\hline $\begin{array}{c}\text { WS12- } \\
24\end{array}$ & MCM & $\begin{array}{c}\mathrm{Sp} \\
2012\end{array}$ & WB & $\mathrm{Ad}$ & $\mathrm{F}$ & 339 & -77.7 & 166.8 \\
\hline $\begin{array}{c}\text { WS12- } \\
25\end{array}$ & MCM & $\begin{array}{c}\mathrm{Sp} \\
2012\end{array}$ & WB & $\mathrm{Ad}$ & $\mathrm{F}$ & 355 & -77.7 & 166.9 \\
\hline $\begin{array}{c}\text { WS12- } \\
26\end{array}$ & MCM & $\begin{array}{c}\mathrm{Sp} \\
2012\end{array}$ & WB & $\mathrm{Ad}$ & $\mathrm{F}$ & 408 & -77.7 & 166.7 \\
\hline G103 & WAP & F 2007 & Serum & $\mathrm{Ad}$ & $\mathrm{F}$ & 306 & -67.2 & -66.9 \\
\hline G111 & WAP & F 2007 & Plasma & $\mathrm{Ad}$ & $\mathrm{F}$ & 280 & -67.1 & -66.8 \\
\hline $\begin{array}{c}\text { LW11- } \\
03\end{array}$ & MCM & $\begin{array}{c}\mathrm{Su} \\
2010 / 11\end{array}$ & WB & Juv & na & na & -74.9 & 163.7 \\
\hline $\begin{array}{c}\text { LW11- } \\
05\end{array}$ & MCM & $\begin{array}{c}\mathrm{Su} \\
2010 / 11\end{array}$ & WB & Juv & na & na & -74.9 & 163.7 \\
\hline $\begin{array}{c}\text { LW11- } \\
06\end{array}$ & MCM & $\begin{array}{c}\mathrm{Su} \\
2010 / 11\end{array}$ & WB & Juv & na & na & -74.9 & 163.7 \\
\hline $\begin{array}{c}\text { LW11- } \\
07\end{array}$ & MCM & $\begin{array}{c}\mathrm{Su} \\
2010 / 11\end{array}$ & WB & Juv & na & na & -74.9 & 163.7 \\
\hline $\begin{array}{c}\text { LW11- } \\
08\end{array}$ & MCM & $\begin{array}{c}\mathrm{Su} \\
2010 / 11\end{array}$ & WB & Juv & na & na & -74.9 & 163.7 \\
\hline $\begin{array}{c}\text { LW11- } \\
09\end{array}$ & MCM & $\begin{array}{c}\mathrm{Su} \\
2010 / 11\end{array}$ & WB & Juv & na & na & -74.9 & 163.7 \\
\hline $\begin{array}{c}\text { LW11- } \\
10\end{array}$ & MCM & $\begin{array}{c}\mathrm{Su} \\
2010 / 11\end{array}$ & WB & Juv & na & na & -74.9 & 163.7 \\
\hline $\begin{array}{c}\text { LW11- } \\
11\end{array}$ & MCM & $\begin{array}{c}\mathrm{Su} \\
2010 / 11\end{array}$ & WB & Juv & na & na & -74.9 & 163.7 \\
\hline $\begin{array}{c}\text { LW11- } \\
12\end{array}$ & MCM & $\begin{array}{c}\mathrm{Su} \\
2010 / 11\end{array}$ & WB & Juv & na & na & -74.9 & 163.7 \\
\hline $\begin{array}{c}\text { LW11- } \\
13\end{array}$ & MCM & $\begin{array}{c}\mathrm{Su} \\
2010 / 11\end{array}$ & WB & Juv & na & na & -74.9 & 163.7 \\
\hline
\end{tabular}




\begin{tabular}{|c|c|c|c|c|c|c|c|c|}
\hline $\begin{array}{c}\text { LW11- } \\
14\end{array}$ & $\mathrm{MCM}$ & $\begin{array}{c}\mathrm{Su} \\
2010 / 11\end{array}$ & WB & Juv & na & na & -74.9 & 163.7 \\
\hline $\begin{array}{c}\text { LW11- } \\
15\end{array}$ & MCM & $\begin{array}{c}\mathrm{Su} \\
2010 / 11\end{array}$ & WB & Juv & na & na & -74.9 & 163.7 \\
\hline $\begin{array}{c}\text { LW15- } \\
01\end{array}$ & $\mathrm{MCM}$ & $\begin{array}{c}\mathrm{Sp} \\
2015\end{array}$ & WB & $\mathrm{Ad}$ & $\mathrm{M}$ & 300 & -77.8 & 166.8 \\
\hline $\begin{array}{c}\text { LW15- } \\
02\end{array}$ & MCM & $\begin{array}{c}\mathrm{Sp} \\
2015\end{array}$ & WB & Sub & $\mathrm{M}$ & 280 & -77.8 & 166.8 \\
\hline $\begin{array}{c}\text { LW15- } \\
03\end{array}$ & MCM & $\begin{array}{c}\mathrm{Sp} \\
2015\end{array}$ & WB & Ad & $\mathrm{M}$ & 300 & -77.8 & 166.8 \\
\hline $\begin{array}{c}\text { LW15- } \\
04\end{array}$ & MCM & $\begin{array}{c}\mathrm{Sp} \\
2015\end{array}$ & WB & Ad & M & 300 & -77.8 & 166.8 \\
\hline $\begin{array}{c}\text { LW15- } \\
05\end{array}$ & MCM & $\begin{array}{c}\mathrm{Sp} \\
2015\end{array}$ & WB & Ad & M & 300 & -77.8 & 166.8 \\
\hline $\begin{array}{c}\text { LW15- } \\
06\end{array}$ & MCM & $\begin{array}{c}\mathrm{Sp} \\
2015\end{array}$ & WB & Ad & M & 300 & -77.7 & 166.4 \\
\hline $\begin{array}{c}\text { LW15- } \\
07\end{array}$ & MCM & $\begin{array}{c}\mathrm{Sp} \\
2015\end{array}$ & WB & $\mathrm{Ad}$ & $\mathrm{F}$ & 350 & -77.7 & 166.4 \\
\hline $\begin{array}{c}\text { LW15- } \\
08\end{array}$ & MCM & $\begin{array}{c}\mathrm{Sp} \\
2015\end{array}$ & WB & Sub & $\mathrm{F}$ & 250 & -77.8 & 166.8 \\
\hline $\begin{array}{c}\text { LW15- } \\
09\end{array}$ & $\mathrm{MCM}$ & $\begin{array}{c}\mathrm{Sp} \\
2015\end{array}$ & WB & Sub & $\mathrm{F}$ & 275 & -77.7 & 166.3 \\
\hline $\begin{array}{c}\text { LW15- } \\
10\end{array}$ & MCM & $\begin{array}{c}\mathrm{Sp} \\
2015\end{array}$ & WB & Sub & $\mathrm{M}$ & 230 & -77.7 & 166.4 \\
\hline $\begin{array}{c}\text { LW15- } \\
11\end{array}$ & MCM & $\begin{array}{c}\mathrm{Sp} \\
2015\end{array}$ & WB & Sub & $\mathrm{F}$ & 250 & -77.7 & 166.4 \\
\hline $\begin{array}{c}\text { LW15- } \\
12\end{array}$ & MCM & $\begin{array}{c}\mathrm{Sp} \\
2015\end{array}$ & WB & Sub & $\mathrm{M}$ & 200 & -77.7 & 166.4 \\
\hline W006 & WAP & \begin{tabular}{|c|}
$\mathrm{Su}$ \\
$2009 / 10$
\end{tabular} & Whisker & $\mathrm{Ad}$ & $\mathrm{M}$ & 293 & -62.5 & -60.8 \\
\hline W013 & WAP & $\begin{array}{c}\mathrm{Su} \\
2009 / 10\end{array}$ & Whisker & $\mathrm{Ad}$ & $\mathrm{F}$ & 293 & -62.5 & -60.8 \\
\hline $\begin{array}{c}\text { WS10- } \\
01\end{array}$ & $\begin{array}{l}\text { Goetz et } \\
\text { al. (2017) }\end{array}$ & $\begin{array}{c}\mathrm{Su} \\
2009 / 10\end{array}$ & Whisker & Ad & $\mathrm{F}$ & 327 & -77.8 & 166.8 \\
\hline $\begin{array}{l}\text { WS10- } \\
02\end{array}$ & $\begin{array}{l}\text { Goetz et } \\
\text { al. (2017) }\end{array}$ & \begin{tabular}{|c|}
$\mathrm{Su}$ \\
$2009 / 10$
\end{tabular} & Whisker & $\mathrm{Ad}$ & $\mathrm{F}$ & 378 & -77.7 & 166.8 \\
\hline $\begin{array}{l}\text { WS10- } \\
03\end{array}$ & $\begin{array}{l}\text { Goetz et } \\
\text { al. (2017) }\end{array}$ & $\begin{array}{c}\mathrm{Su} \\
2009 / 10\end{array}$ & Whisker & $\mathrm{Ad}$ & $\mathrm{F}$ & 214 & -77.7 & 166.7 \\
\hline $\begin{array}{l}\text { WS10- } \\
04\end{array}$ & $\begin{array}{l}\text { Goetz et } \\
\text { al. (2017) }\end{array}$ & $\begin{array}{c}\mathrm{Su} \\
2009 / 10\end{array}$ & Whisker & Ad & $\mathrm{F}$ & 195 & -77.7 & 166.7 \\
\hline $\begin{array}{l}\text { WS10- } \\
05\end{array}$ & $\begin{array}{c}\text { Goetz et } \\
\text { al. (2017) }\end{array}$ & $\begin{array}{c}\mathrm{Su} \\
2009 / 10\end{array}$ & Whisker & Ad & $\mathrm{F}$ & 271 & -77.7 & 166.7 \\
\hline $\begin{array}{l}\text { WS10- } \\
06\end{array}$ & $\begin{array}{l}\text { Goetz et } \\
\text { al. (2017) }\end{array}$ & $\begin{array}{c}\mathrm{Su} \\
2009 / 10\end{array}$ & Whisker & $\mathrm{Ad}$ & $\mathrm{M}$ & 271 & -77.6 & 166.2 \\
\hline $\begin{array}{l}\text { WS10- } \\
07\end{array}$ & $\begin{array}{c}\text { Goetz et } \\
\text { al. (2017) }\end{array}$ & $\begin{array}{c}\mathrm{Su} \\
2009 / 10\end{array}$ & Whisker & $\mathrm{Ad}$ & $\mathrm{F}$ & 234 & -77.7 & 166.7 \\
\hline $\begin{array}{c}\text { WS10- } \\
19\end{array}$ & $\begin{array}{c}\text { Goetz et } \\
\text { al. (2017) }\end{array}$ & $\begin{array}{c}\mathrm{Su} \\
2009 / 10\end{array}$ & Whisker & Ad & $\mathrm{M}$ & 184 & -76.6 & 162.7 \\
\hline $\begin{array}{l}\text { WS10- } \\
20\end{array}$ & $\begin{array}{c}\text { Goetz et } \\
\text { al. (2017) }\end{array}$ & $\begin{array}{c}\mathrm{Su} \\
2009 / 10\end{array}$ & Whisker & Ad & $\mathrm{M}$ & 181 & -76.6 & 162.7 \\
\hline $\begin{array}{l}\text { WS10- } \\
21\end{array}$ & $\begin{array}{l}\text { Goetz et } \\
\text { al. (2017) }\end{array}$ & $\begin{array}{c}\mathrm{Su} \\
2009 / 10\end{array}$ & Whisker & $\mathrm{Ad}$ & $\mathrm{F}$ & 393 & -77.8 & 166.8 \\
\hline $\begin{array}{l}\text { WS10- } \\
22\end{array}$ & $\begin{array}{l}\text { Goetz et } \\
\text { al. (2017) }\end{array}$ & $\begin{array}{c}\mathrm{Su} \\
2009 / 10\end{array}$ & Whisker & Ad & $\mathrm{M}$ & 290 & -77.8 & 166.8 \\
\hline
\end{tabular}




\begin{tabular}{|c|c|c|c|c|c|c|c|c|}
\hline $\begin{array}{l}\text { WS11- } \\
03\end{array}$ & $\begin{array}{l}\text { Goetz et } \\
\text { al. }(2017)\end{array}$ & $\begin{array}{c}\mathrm{Su} \\
2010 / 11\end{array}$ & Whisker & $\mathrm{Ad}$ & $\mathrm{F}$ & 367 & -77.9 & 166.8 \\
\hline $\begin{array}{l}\text { WS11- } \\
04\end{array}$ & $\begin{array}{l}\text { Goetz et } \\
\text { al. (2017) }\end{array}$ & $\begin{array}{c}\mathrm{Su} \\
2010 / 11\end{array}$ & Whisker & $\mathrm{Ad}$ & $\mathrm{F}$ & 402 & -77.9 & 166.8 \\
\hline $\begin{array}{l}\text { WS11- } \\
05\end{array}$ & $\begin{array}{l}\text { Goetz et } \\
\text { al. (2017) }\end{array}$ & $\begin{array}{c}\mathrm{Su} \\
2010 / 11\end{array}$ & Whisker & $\mathrm{Ad}$ & M & 197 & -76.6 & 162.7 \\
\hline $\begin{array}{l}\text { WS11- } \\
06\end{array}$ & $\begin{array}{l}\text { Goetz et } \\
\text { al. (2017) }\end{array}$ & $\begin{array}{c}\mathrm{Su} \\
2010 / 11\end{array}$ & Whisker & Ad & $\mathrm{F}$ & 206 & -76.6 & 162.7 \\
\hline $\begin{array}{l}\text { WS11- } \\
08\end{array}$ & $\begin{array}{l}\text { Goetz et } \\
\text { al. (2017) }\end{array}$ & $\begin{array}{c}\mathrm{Su} \\
2010 / 11\end{array}$ & Whisker & Ad & $\mathrm{F}$ & 277 & -76.6 & 162.7 \\
\hline $\begin{array}{l}\text { WS11- } \\
09\end{array}$ & $\begin{array}{l}\text { Goetz et } \\
\text { al. (2017) }\end{array}$ & $\begin{array}{c}\mathrm{Su} \\
2010 / 11\end{array}$ & Whisker & Ad & $\mathrm{F}$ & 336 & -77.9 & 166.8 \\
\hline $\begin{array}{c}\text { WS11- } \\
17\end{array}$ & $\begin{array}{l}\text { Goetz et } \\
\text { al. (2017) }\end{array}$ & $\begin{array}{c}\mathrm{Su} \\
2010 / 11\end{array}$ & Whisker & Ad & $\mathrm{F}$ & 359 & -77.9 & 166.7 \\
\hline $\begin{array}{c}\text { WS11- } \\
18\end{array}$ & $\begin{array}{l}\text { Goetz et } \\
\text { al. (2017) }\end{array}$ & $\begin{array}{c}\mathrm{Su} \\
2010 / 11\end{array}$ & Whisker & Ad & $\mathrm{F}$ & 247 & -77.9 & 166.7 \\
\hline $\begin{array}{c}\text { WS11- } \\
19\end{array}$ & $\begin{array}{l}\text { Goetz et } \\
\text { al. }(2017)\end{array}$ & $\begin{array}{c}\mathrm{Su} \\
2010 / 11\end{array}$ & Whisker & Ad & M & 266 & -77.7 & 166.7 \\
\hline $\begin{array}{l}\text { WS11- } \\
21\end{array}$ & $\begin{array}{l}\text { Goetz et } \\
\text { al. }(2017)\end{array}$ & $\begin{array}{c}\mathrm{Su} \\
2010 / 11\end{array}$ & Whisker & $\mathrm{Ad}$ & $\mathrm{F}$ & 382 & -77.9 & 166.8 \\
\hline $\begin{array}{l}\text { WS11- } \\
37\end{array}$ & $\begin{array}{l}\text { Goetz et } \\
\text { al. }(2017)\end{array}$ & $\begin{array}{c}\mathrm{Su} \\
2011 / 12\end{array}$ & Whisker & Ad & M & 331 & -77.4 & 166.3 \\
\hline $\begin{array}{l}\text { WS11- } \\
38\end{array}$ & $\begin{array}{l}\text { Goetz et } \\
\text { al. (2017) }\end{array}$ & $\begin{array}{c}\mathrm{Su} \\
2011 / 12\end{array}$ & Whisker & Ad & M & 268 & -77.4 & 166.3 \\
\hline $\begin{array}{c}\text { WS11- } \\
39\end{array}$ & $\begin{array}{l}\text { Goetz et } \\
\text { al. (2017) }\end{array}$ & $\begin{array}{c}\mathrm{Su} \\
2011 / 12\end{array}$ & Whisker & $\mathrm{Ad}$ & M & 268 & -77.7 & 166.3 \\
\hline $\begin{array}{l}\text { WS11- } \\
40\end{array}$ & $\begin{array}{l}\text { Goetz et } \\
\text { al. (2017) }\end{array}$ & $\begin{array}{c}\mathrm{Su} \\
2011 / 12\end{array}$ & Whisker & $\mathrm{Ad}$ & M & 268 & -77.7 & 166.3 \\
\hline $\begin{array}{l}\text { WS11- } \\
41\end{array}$ & $\begin{array}{l}\text { Goetz et } \\
\text { al. (2017) }\end{array}$ & $\begin{array}{c}\mathrm{Su} \\
2011 / 12\end{array}$ & Whisker & Ad & M & 268 & -77.7 & 166.3 \\
\hline $\begin{array}{l}\text { WS12- } \\
01\end{array}$ & $\begin{array}{l}\text { Goetz et } \\
\text { al. (2017) }\end{array}$ & $\begin{array}{c}\mathrm{Su} \\
2011 / 12\end{array}$ & Whisker & Ad & $\mathrm{F}$ & 405 & -77.9 & 166.8 \\
\hline $\begin{array}{c}\text { WS12- } \\
02\end{array}$ & $\begin{array}{l}\text { Goetz et } \\
\text { al. (2017) }\end{array}$ & $\begin{array}{c}\mathrm{Su} \\
2011 / 12\end{array}$ & Whisker & Ad & $\mathrm{F}$ & 351 & -77.0 & 162.8 \\
\hline $\begin{array}{c}\text { WS12- } \\
04\end{array}$ & $\begin{array}{l}\text { Goetz et } \\
\text { al. (2017) }\end{array}$ & $\begin{array}{c}\mathrm{Su} \\
2011 / 12\end{array}$ & Whisker & Ad & $\mathrm{F}$ & 351 & -77.9 & 166.8 \\
\hline $\begin{array}{l}\text { WS12- } \\
05\end{array}$ & $\begin{array}{l}\text { Goetz et } \\
\text { al. (2017) }\end{array}$ & $\begin{array}{c}\mathrm{Su} \\
2011 / 12\end{array}$ & Whisker & Ad & $\mathrm{F}$ & 386 & -76.6 & 166.7 \\
\hline $\begin{array}{l}\text { WS12- } \\
06\end{array}$ & $\begin{array}{l}\text { Goetz et } \\
\text { al. (2017) }\end{array}$ & $\begin{array}{c}\mathrm{Su} \\
2011 / 12\end{array}$ & Whisker & Ad & $\mathrm{F}$ & 332 & -76.5 & 166.8 \\
\hline $\begin{array}{c}\text { WS12- } \\
07\end{array}$ & $\begin{array}{l}\text { Goetz et } \\
\text { al. }(2017)\end{array}$ & $\begin{array}{c}\mathrm{Su} \\
2011 / 12\end{array}$ & Whisker & $\mathrm{Ad}$ & $\mathrm{F}$ & 416 & -77.8 & 166.8 \\
\hline $\begin{array}{l}\text { WS12- } \\
08\end{array}$ & $\begin{array}{l}\text { Goetz et } \\
\text { al. (2017) }\end{array}$ & $\begin{array}{c}\mathrm{Su} \\
2011 / 12\end{array}$ & Whisker & $\mathrm{Ad}$ & $\mathrm{F}$ & 429 & -77.8 & 166.8 \\
\hline $\begin{array}{c}\text { WS12- } \\
09\end{array}$ & $\begin{array}{l}\text { Goetz et } \\
\text { al. (2017) }\end{array}$ & $\begin{array}{c}\mathrm{Su} \\
2011 / 12\end{array}$ & Whisker & $\mathrm{Ad}$ & $\mathrm{F}$ & 429 & -77.8 & 166.8 \\
\hline $\begin{array}{c}\text { WS12- } \\
10\end{array}$ & $\begin{array}{l}\text { Goetz et } \\
\text { al. (2017) }\end{array}$ & $\begin{array}{c}\mathrm{Su} \\
2011 / 12\end{array}$ & Whisker & Ad & $\mathrm{M}$ & 221 & -76.6 & 162.9 \\
\hline $\begin{array}{l}\text { WS12- } \\
16\end{array}$ & $\begin{array}{l}\text { Goetz et } \\
\text { al. (2017) }\end{array}$ & $\begin{array}{c}\mathrm{Su} \\
2011 / 12\end{array}$ & Whisker & $\mathrm{Ad}$ & $\mathrm{M}$ & 230 & -76.5 & 162.7 \\
\hline $\begin{array}{c}\text { WS12- } \\
17\end{array}$ & $\begin{array}{l}\text { Goetz et } \\
\text { al. (2017) }\end{array}$ & $\begin{array}{c}\mathrm{Su} \\
2011 / 12\end{array}$ & Whisker & $\mathrm{Ad}$ & $\mathrm{F}$ & 230 & -77.8 & 166.8 \\
\hline $\begin{array}{l}\text { WS12- } \\
19\end{array}$ & $\begin{array}{l}\text { Goetz et } \\
\text { al. (2017) }\end{array}$ & $\begin{array}{c}\mathrm{Su} \\
2011 / 12\end{array}$ & Whisker & Ad & $\mathrm{F}$ & 230 & -77.9 & 166.8 \\
\hline
\end{tabular}


Antarctic Seal Foraging Ecology

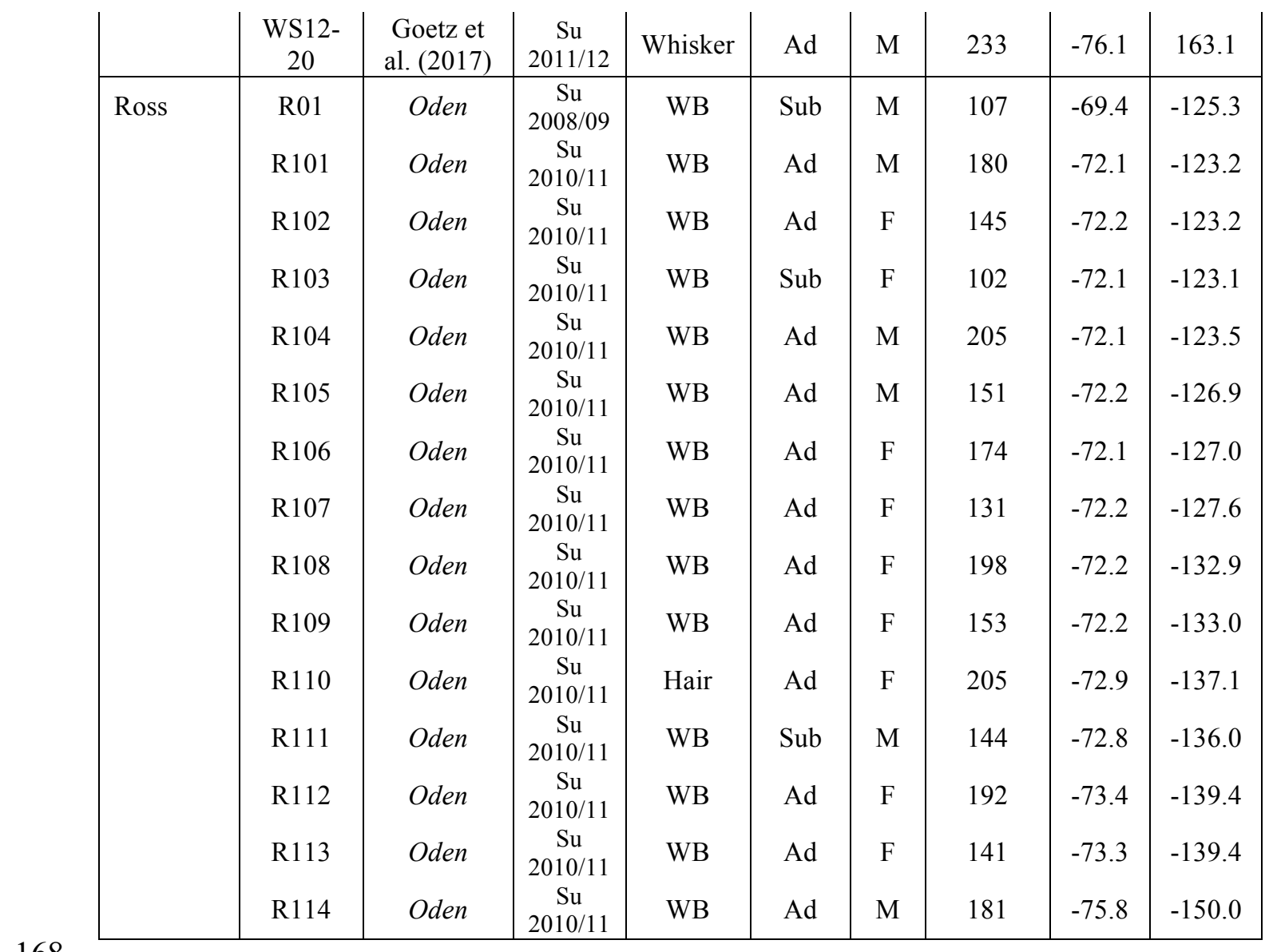




\section{Antarctic Seal Foraging Ecology}

169

170

171

172

173

174

Table S2. Effect of lipid extraction on isotopic values of crabeater, Weddell, and Ross seals. Sample ID as in Table S1. Abbreviations: WB, whole blood without lipid extraction; LE, whole blood with lipid extraction. The difference in isotopic value between whole blood samples with and without lipid extraction is reported. The average difference is $0.0 \pm 0.1 \%$ and $0.2 \pm 0.1 \%$ for $\delta^{13} \mathrm{C}$ and $\delta^{15} \mathrm{~N}$, respectively. The average difference between the isotopic values with and without lipid extraction do not exceed the instrument error of $0.2 \%$ for either $\delta^{13} \mathrm{C}$ and $\delta^{15} \mathrm{~N}$ values.

\begin{tabular}{|c|c|c|c|c|c|c|c|c|c|}
\hline Species & $\begin{array}{c}\text { Sample } \\
\text { ID }\end{array}$ & Year & $\begin{array}{c}\text { Sample } \\
\text { Type }\end{array}$ & $\begin{array}{l}\delta^{13} \mathrm{C} \\
(\%)\end{array}$ & $\begin{array}{c}\text { LE } \\
\delta^{13} \mathbf{C} \\
(\%)\end{array}$ & $\begin{array}{l}\delta^{15} N \\
(\%)\end{array}$ & $\begin{array}{c}\text { LE } \\
\delta^{15} \mathbf{N} \\
(\%)\end{array}$ & $\begin{array}{c}\delta^{13} \mathbf{C}- \\
\mathbf{L E} \\
\boldsymbol{\delta}^{13} \mathbf{C} \\
(\%)\end{array}$ & $\begin{array}{c}\delta^{15} \mathbf{N}- \\
\mathbf{L E} \\
\boldsymbol{\delta}^{15} \mathbf{N} \\
(\%)\end{array}$ \\
\hline \multirow[t]{9}{*}{ Crabeater } & $\mathrm{C} 03$ & 2008 & WB & -26.3 & -26.5 & 8.2 & 8.0 & 0.2 & 0.2 \\
\hline & C06 & 2008 & WB & -26.5 & -26.6 & 8.6 & 8.5 & 0.1 & 0.1 \\
\hline & C07 & 2008 & WB & -26.2 & -26.3 & 8.5 & 8.3 & 0.1 & 0.2 \\
\hline & C20 & 2008 & WB & -26.0 & -26.0 & 8.1 & 7.9 & 0.0 & 0.2 \\
\hline & C46 & 2008 & WB & -26.0 & -26.0 & 8.2 & 8.1 & 0.0 & 0.1 \\
\hline & C52 & 2008 & WB & -25.5 & -25.7 & 7.3 & 7.1 & 0.2 & 0.2 \\
\hline & C153 & 2010 & WB & -25.9 & -25.9 & 7.3 & 7.2 & 0.0 & 0.1 \\
\hline & C154 & 2010 & WB & -26.1 & -26.1 & 7.0 & 6.9 & 0.0 & 0.1 \\
\hline & C176 & 2010 & WB & -26.6 & -26.7 & 7.2 & 7.0 & 0.1 & 0.2 \\
\hline \multirow[t]{5}{*}{ Weddell } & W12 & 2008 & WB & -25.1 & -25.1 & 12.3 & 12.1 & 0.0 & 0.2 \\
\hline & W15 & 2008 & WB & -25.3 & -25.3 & 11.4 & 11.2 & 0.0 & 0.2 \\
\hline & W117 & 2010 & WB & -24.9 & -24.9 & 12.0 & 11.8 & 0.0 & 0.2 \\
\hline & W216 & 2010 & WB & -25.1 & -25.2 & 13.2 & 13.1 & 0.1 & 0.1 \\
\hline & W223 & 2010 & WB & -24.9 & -24.9 & 13.9 & 13.8 & 0.0 & 0.1 \\
\hline \multirow[t]{7}{*}{ Ross } & R01 & 2008 & WB & -23.2 & -23.2 & 8.5 & 8.4 & 0.0 & 0.1 \\
\hline & R101 & 2010 & WB & -23.9 & -23.9 & 9.6 & 9.4 & 0.0 & 0.2 \\
\hline & R102 & 2010 & WB & -23.6 & -23.7 & 9.0 & 8.8 & 0.1 & 0.2 \\
\hline & R103 & 2010 & WB & -24.0 & -24.0 & 9.0 & 8.8 & 0.0 & 0.2 \\
\hline & R108 & 2010 & WB & -24.6 & -24.7 & 10.0 & 9.8 & 0.1 & 0.2 \\
\hline & R112 & 2010 & WB & -23.8 & -23.8 & 9.7 & 9.6 & 0.0 & 0.1 \\
\hline & R114 & 2010 & WB & -23.7 & -23.7 & 8.6 & 8.5 & 0.0 & 0.1 \\
\hline
\end{tabular}


176 Table S3. Bulk $\delta^{13} \mathrm{C}$ and $\delta^{15} \mathrm{~N}$ values of crabeater, Weddell, and Ross seals for multiple tissue types.

177 These isotopic values are used to calculate the isotopic offsets between different tissue types, see Table

178 S4 below. Abbreviations are as in Tables S1.

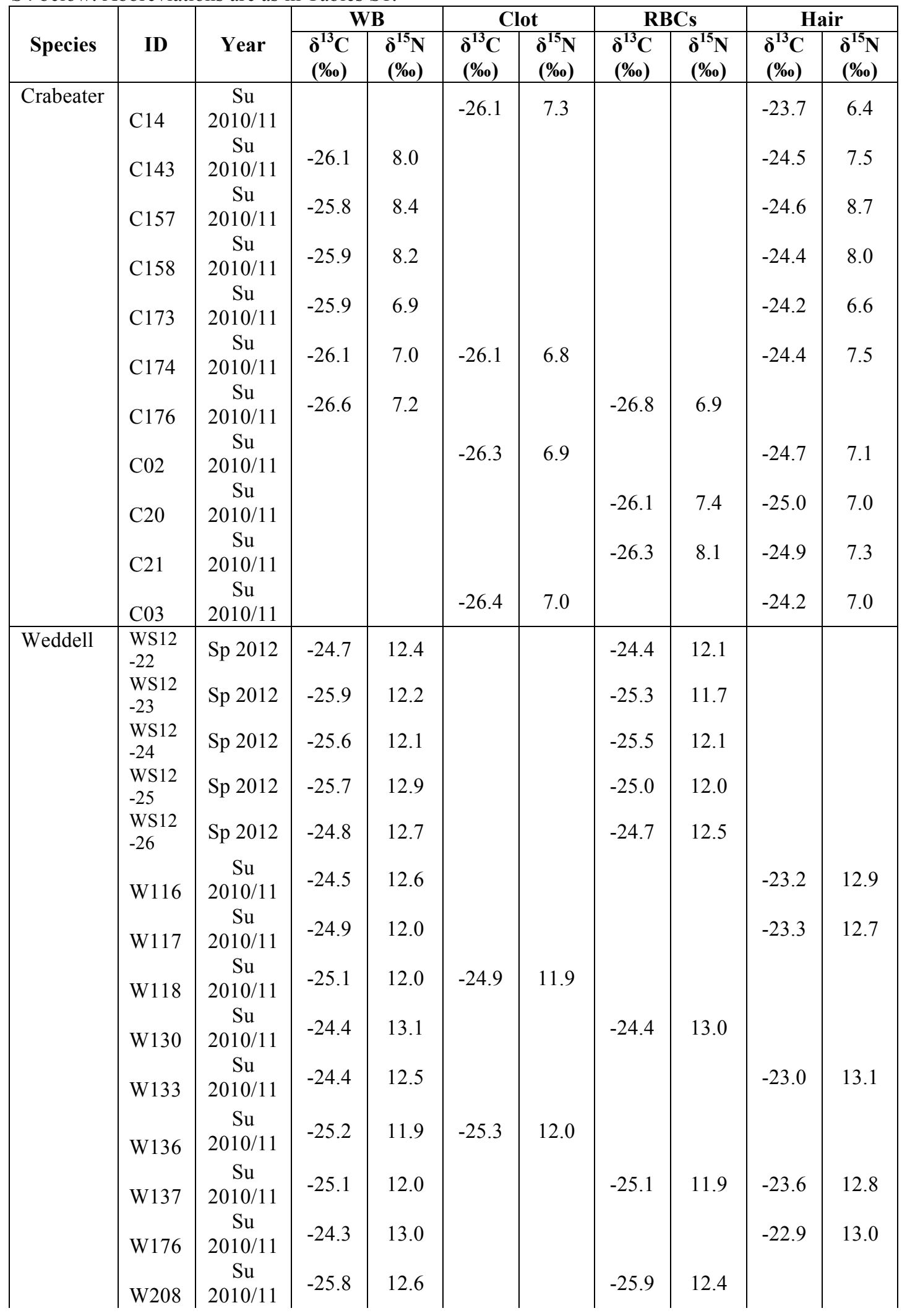


Antarctic Seal Foraging Ecology

\begin{tabular}{|c|c|c|c|c|c|c|c|c|}
\hline & $\begin{array}{l}\text { W216 } \\
\text { W219 } \\
\text { W220 } \\
\text { W04 } \\
\text { W06 }\end{array}$ & $\begin{array}{c}\mathrm{Su} \\
2010 / 11 \\
\mathrm{Su} \\
2010 / 11 \\
\mathrm{Su} \\
2010 / 11 \\
\mathrm{Su} \\
2010 / 11 \\
\mathrm{Su} \\
2010 / 11 \\
\end{array}$ & $\begin{array}{l}-25.1 \\
-25.6 \\
-25.0\end{array}$ & $\begin{array}{l}13.2 \\
11.9 \\
12.6\end{array}$ & $\begin{array}{l}-25.0 \\
-25.4 \\
-25.0 \\
-24.8 \\
-24.7\end{array}$ & $\begin{array}{r}13.2 \\
11.9 \\
12.4 \\
12.2 \\
12.2\end{array}$ & $\begin{array}{l}-23.5 \\
-23.5\end{array}$ & $\begin{array}{l}12.6 \\
12.2\end{array}$ \\
\hline Ross & $\begin{array}{l}\text { R101 } \\
\text { R103 } \\
\text { R105 } \\
\text { R107 } \\
\text { R108 }\end{array}$ & $\begin{array}{c}\mathrm{Su} \\
2010 / 11 \\
\mathrm{Su} \\
2010 / 11 \\
\mathrm{Su} \\
2010 / 11 \\
\mathrm{Su} \\
2010 / 11 \\
\mathrm{Su} \\
2010 / 11\end{array}$ & $\begin{array}{l}-23.9 \\
-24.0 \\
-23.6 \\
-23.6 \\
-24.6\end{array}$ & $\begin{array}{l}9.6 \\
9.0 \\
9.2 \\
8.8 \\
10.0\end{array}$ & & & $\begin{array}{l}-22.6 \\
-22.8 \\
-22.4 \\
-22.4 \\
-23.0\end{array}$ & $\begin{array}{l}10.3 \\
11.0 \\
10.1 \\
10.5 \\
10.8\end{array}$ \\
\hline
\end{tabular}




\section{Antarctic Seal Foraging Ecology}

183

184

185

186

Table S4. Calculated isotopic offsets between different tissue types for crabeater, Weddell, and Ross seals. Abbreviations are as in Tables S1. If a calculated mean offset is $\leq 0.2 \%$, then the offset between the two tissue types is considered insignificant (less than instrumental error as indicated by the quality control standard).

\begin{tabular}{|c|c|c|c|c|c|c|}
\hline Species & Offset Type & $\begin{array}{c}\text { Sample } \\
\text { ID }\end{array}$ & $\begin{array}{c}\delta^{13} \mathrm{C} \\
\text { Offset (\%o) }\end{array}$ & $\begin{array}{c}\delta^{15} \mathrm{~N} \\
\text { Offset (\%o) }\end{array}$ & $\begin{array}{l}\text { Mean } \delta^{13} \mathbf{C} \\
\text { Offset (\%o) }\end{array}$ & $\begin{array}{l}\text { Mean } \delta^{15} N \\
\text { Offset (\%o) }\end{array}$ \\
\hline \multirow[t]{13}{*}{ Crabeater } & WB - Clot & $\mathrm{C} 174$ & 0.0 & 0.2 & 0.0 & 0.2 \\
\hline & WB - RBCs & $\mathrm{C} 176$ & 0.2 & 0.2 & 0.2 & 0.2 \\
\hline & WB - Hair & C143 & -1.6 & 0.4 & -1.6 & 0.0 \\
\hline & & $\mathrm{C} 157$ & -1.2 & -0.3 & & \\
\hline & & $\mathrm{C} 158$ & -1.5 & 0.2 & & \\
\hline & & $\mathrm{C} 173$ & -1.7 & 0.3 & & \\
\hline & & $\mathrm{C} 174$ & -1.7 & -0.5 & & \\
\hline & Clot - Hair & $\mathrm{C} 14$ & -2.4 & 0.9 & -2.0 & 0.0 \\
\hline & & C174 & -1.7 & -0.7 & & \\
\hline & & $\mathrm{C} 2$ & -1.5 & -0.2 & & \\
\hline & & $\mathrm{C} 3$ & -2.1 & 0.0 & & \\
\hline & RBCs - Hair & $\mathrm{C} 20$ & -1.1 & 0.4 & -1.3 & 0.6 \\
\hline & & $\mathrm{C} 21$ & -1.5 & 0.8 & & \\
\hline \multirow[t]{21}{*}{ Weddell } & WB - Clot & W118 & -0.2 & 0.1 & -0.1 & 0.1 \\
\hline & & W136 & 0.1 & -0.1 & & \\
\hline & & W216 & -0.1 & 0.0 & & \\
\hline & & W219 & -0.2 & 0.0 & & \\
\hline & & W220 & 0.0 & 0.2 & & \\
\hline & WB - RBCs & WS12-22 & -0.2 & 0.3 & -0.2 & 0.3 \\
\hline & & WS12-23 & -0.6 & 0.4 & & \\
\hline & & WS12-24 & -0.2 & 0.1 & & \\
\hline & & WS12-25 & -0.7 & 0.9 & & \\
\hline & & WS12-26 & -0.1 & 0.2 & & \\
\hline & & W130 & 0.1 & 0.1 & & \\
\hline & & W137 & 0.0 & 0.0 & & \\
\hline & & W208 & 0.0 & 0.2 & & \\
\hline & WB - Hair & W116 & -1.3 & -0.3 & -1.4 & -0.5 \\
\hline & & W117 & -1.5 & -0.7 & & \\
\hline & & W133 & -1.4 & -0.6 & & \\
\hline & & W137 & -1.5 & -0.9 & & \\
\hline & & W176 & -1.4 & 0.0 & & \\
\hline & Clot - Hair & W4 & -1.3 & -0.4 & -1.2 & -0.2 \\
\hline & & W6 & -1.2 & 0.0 & & \\
\hline & RBCs - Hair & W137 & -1.5 & -0.9 & -1.5 & -0.9 \\
\hline
\end{tabular}


Antarctic Seal Foraging Ecology

\begin{tabular}{|l|l|l|l|l|l|l|}
\hline Ross & WB - Hair & R101 & -1.3 & -0.7 & -1.3 & -1.2 \\
& & R103 & -1.2 & -2.0 & & \\
& & R105 & -1.2 & -0.9 & & \\
& & R107 & -1.2 & -1.6 & & \\
& & R108 & -1.6 & -0.8 & & \\
\hline
\end{tabular}




\section{Antarctic Seal Foraging Ecology}

192 Table S5. Bulk $\delta^{13} \mathrm{C}$ and $\delta^{15} \mathrm{~N}$ values of Weddell seals for multiple blood sample types. These

193 isotopic values are used to calculate the isotopic offsets between these different sample types, see

194 Table S6 below. Abbreviations are as in Tables S1.

\begin{tabular}{|c|c|c|c|c|c|c|c|c|c|}
\hline \multirow[b]{2}{*}{ ID } & \multirow[b]{2}{*}{ Year } & \multicolumn{2}{|c|}{ WB } & \multicolumn{2}{|c|}{ Plasma } & \multicolumn{2}{|c|}{ Serum } & \multicolumn{2}{|c|}{ RBCs } \\
\hline & & $\begin{array}{l}\delta^{13} C \\
(\% o)\end{array}$ & $\begin{array}{l}\delta^{15} N \\
(\% \%)\end{array}$ & $\begin{array}{l}\delta^{13} C \\
(\%)\end{array}$ & $\begin{array}{l}\delta^{15} \mathbf{N} \\
(\% \%)\end{array}$ & $\begin{array}{l}\delta^{13} \mathbf{C} \\
(\% \%)\end{array}$ & $\begin{array}{l}\delta^{15} N \\
(\% \%)\end{array}$ & $\begin{array}{l}\delta^{13} C \\
(\%)\end{array}$ & $\begin{array}{l}\delta^{15} N \\
(\% \%)\end{array}$ \\
\hline LW15-01 & Sp 2015 & -25.8 & 12.1 & -26.4 & 12.3 & -26.2 & 12.7 & & \\
\hline LW15-02 & Sp 2015 & -25.2 & 12.1 & -25.6 & 13.0 & -25.3 & 13.4 & & \\
\hline LW15-03 & Sp 2015 & -25.3 & 12.1 & -25.7 & 12.7 & -25.5 & 13.1 & & \\
\hline LW15-11 & Sp 2015 & -25.3 & 12.2 & -26.2 & 12.8 & -25.8 & 13.3 & & \\
\hline LW15-12 & Sp 2015 & -25.2 & 11.9 & -25.8 & 12.8 & -25.5 & 13.3 & & \\
\hline WS12-22 & Sp 2012 & -24.7 & 12.4 & & & & & -24.4 & 12.1 \\
\hline WS12-23 & Sp 2012 & -25.9 & 12.2 & & & & & -25.3 & 11.7 \\
\hline WS12-24 & Sp 2012 & -25.6 & 12.1 & & & & & -25.5 & 12.1 \\
\hline WS12-25 & Sp 2012 & -25.7 & 12.9 & & & & & -25.0 & 12.0 \\
\hline WS12-26 & Sp 2012 & -24.8 & 12.7 & & & & & -24.7 & 12.5 \\
\hline W130 & $\mathrm{Su} 2010 / 11$ & -24.4 & 13.1 & & & & & -24.4 & 13.0 \\
\hline W137 & Su $2010 / 11$ & -25.1 & 12.0 & & & & & -25.1 & 11.9 \\
\hline W208 & Su $2010 / 11$ & -25.8 & 12.6 & & & & & -25.9 & 12.4 \\
\hline
\end{tabular}

195

196 


\section{Antarctic Seal Foraging Ecology}

197

Table S6. Calculated isotopic offsets between different blood sample types for Weddell seals. Abbreviations are as in Tables S1. If a calculated mean offset is $\leq 0.2 \%$, then the offset between the two sample types is considered insignificant (less than instrumental error as indicated by the quality control standard).

\begin{tabular}{|c|c|c|c|c|c|}
\hline Offset Type & Sample ID & $\begin{array}{c}\delta^{13} \text { C Offset } \\
(\%)\end{array}$ & $\begin{array}{c}\delta^{15} \text { N Offset } \\
\text { (\%) }\end{array}$ & $\begin{array}{l}\text { Mean } \delta^{13} \mathrm{C} \\
\text { Offset (\%o) }\end{array}$ & $\begin{array}{l}\text { Mean } \delta^{15} N \\
\text { Offset (\%) }\end{array}$ \\
\hline \multirow[t]{5}{*}{ Plasma - Serum } & LW15-01 & -0.2 & -0.4 & \multirow[t]{5}{*}{-0.3} & \multirow[t]{5}{*}{-0.4} \\
\hline & LW15-02 & -0.3 & -0.4 & & \\
\hline & LW15-03 & -0.2 & -0.4 & & \\
\hline & LW15-11 & -0.3 & -0.5 & & \\
\hline & LW15-12 & -0.3 & -0.5 & & \\
\hline \multirow{5}{*}{ WB - Serum } & LW15-01 & 0.4 & -0.6 & \multirow[t]{5}{*}{0.3} & \multirow[t]{5}{*}{-1.1} \\
\hline & LW15-02 & 0.2 & -1.3 & & \\
\hline & LW15-03 & 0.1 & -1.0 & & \\
\hline & LW15-11 & 0.5 & -1.2 & & \\
\hline & LW15-12 & 0.3 & -1.4 & & \\
\hline \multirow[t]{5}{*}{ WB - Plasma } & LW15-01 & 0.5 & -0.2 & \multirow[t]{5}{*}{0.6} & \multirow[t]{5}{*}{-0.7} \\
\hline & LW15-02 & 0.4 & -0.9 & & \\
\hline & LW15-03 & 0.4 & -0.6 & & \\
\hline & LW15-11 & 0.9 & -0.7 & & \\
\hline & LW15-12 & 0.6 & -0.9 & & \\
\hline \multirow[t]{8}{*}{$\mathrm{WB}-\mathrm{RBCs}$} & WS12-22 & -0.3 & 0.3 & \multirow[t]{8}{*}{-0.2} & \multirow{8}{*}{0.3} \\
\hline & WS12-23 & -0.6 & 0.5 & & \\
\hline & WS12-24 & -0.1 & 0.0 & & \\
\hline & WS12-25 & -0.7 & 0.9 & & \\
\hline & WS12-26 & -0.1 & 0.2 & & \\
\hline & W130 & 0.1 & 0.1 & & \\
\hline & W137 & 0.0 & 0.0 & & \\
\hline & W208 & 0.0 & 0.2 & & \\
\hline
\end{tabular}




\section{Antarctic Seal Foraging Ecology}

206

207

208

209

210

211

212

213

214

Table S7. Bulk $\delta^{13} \mathrm{C}$ and $\delta^{15} \mathrm{~N}$ values of crabeater, Weddell, and Ross seals. Note, bulk $\delta^{13} \mathrm{C}$ and $\delta^{15} \mathrm{~N}$ values are reported for the original measurement (Orig.) and with a correction to whole blood (Corr.) if the sample is a tissue type with a significant isotopic offset from whole blood. Isotopic offset between whole blood and the given sample type are reported in Tables S4 and S6, above. Atomic C:N ratios are from the original measurements. Samples with an asterisk and two asterisks are from Hückstädt et al. (2012a) and Goetz et al. (2017), correspondingly; all other data are from this study. Whisker data are from the segment representing the most recent time period, which best overlaps with the collection location and integrated time of blood tissues, except data from Hückstädt et al. (2012a) are an average for all segments. Abbreviations are as in Table S1. Additionally, "WAP," "RS," and "AM"

abbreviate "West Antarctic Peninsula," "Ross Sea," and "Amundsen Sea," respectively.

\begin{tabular}{|c|c|c|c|c|c|c|c|c|c|}
\hline Species & Sample ID & Season & Region & $\begin{array}{c}\text { Sample } \\
\text { Type }\end{array}$ & $\begin{array}{l}\text { Orig. } \\
\delta^{13} \mathbf{C} \\
(\%)\end{array}$ & $\begin{array}{l}\text { Orig. } \\
\delta^{15} \mathrm{~N} \\
(\%)\end{array}$ & $\begin{array}{l}\text { Corr. } \\
\delta^{13} \mathbf{C} \\
(\%)\end{array}$ & $\begin{array}{c}\text { Corr. } \\
\delta^{15} \mathbf{N} \\
(\%)\end{array}$ & $\begin{array}{c}\text { Atomic } \\
\mathrm{C}: \mathrm{N}\end{array}$ \\
\hline Crabeater & 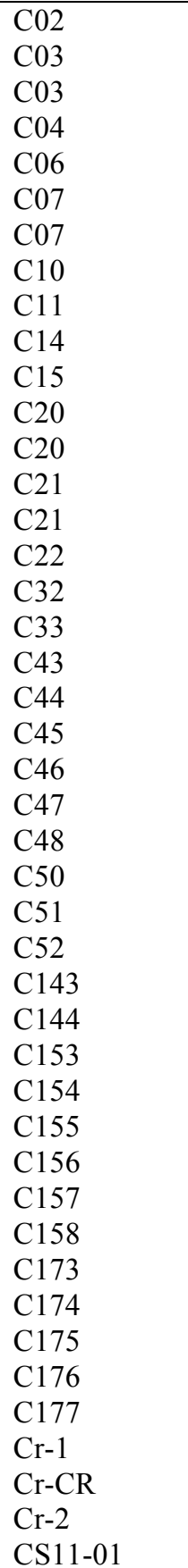 & 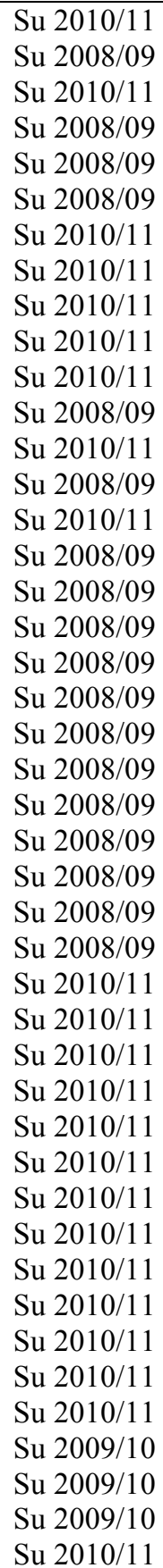 & $\begin{array}{l}\text { AM } \\
\text { AM } \\
\text { AM } \\
\text { AM } \\
\text { AM } \\
\text { AM } \\
\text { AM } \\
\text { AM } \\
\text { AM } \\
\text { AM } \\
\text { AM } \\
\text { AM } \\
\text { AM } \\
\text { AM } \\
\text { AM } \\
\text { AM } \\
\text { AM } \\
\text { AM } \\
\text { AM } \\
\text { AM } \\
\text { AM } \\
\text { AM } \\
\text { RS } \\
\text { RS } \\
\text { RS } \\
\text { RS } \\
\text { RS } \\
\text { AM } \\
\text { AM } \\
\text { AM } \\
\text { AM } \\
\text { AM } \\
\text { AM } \\
\text { AM } \\
\text { AM } \\
\text { AM } \\
\text { AM } \\
\text { AM } \\
\text { AM } \\
\text { RS } \\
\text { RS } \\
\text { RS } \\
\text { RS } \\
\text { RS }\end{array}$ & $\begin{array}{l}\text { Clot } \\
\text { WB } \\
\text { Clot } \\
\text { WB } \\
\text { WB } \\
\text { Wair } \\
\text { Hair } \\
\text { Hair } \\
\text { Clot } \\
\text { WB } \\
\text { WB } \\
\text { RBCs } \\
\text { Clot } \\
\text { RBCs } \\
\text { Clot } \\
\text { WB } \\
\text { WB } \\
\text { WB } \\
\text { WB } \\
\text { WB } \\
\text { WB } \\
\text { WB } \\
\text { WB } \\
\text { WB } \\
\text { WB } \\
\text { WB } \\
\text { WB } \\
\text { WB } \\
\text { WB } \\
\text { WB } \\
\text { Hair } \\
\text { WB } \\
\text { WB } \\
\text { WB } \\
\text { WB } \\
\text { WB } \\
\text { Hair } \\
\text { WB } \\
\text { WB } \\
\text { Hair } \\
\text { Hair } \\
\text { WB }\end{array}$ & $\begin{array}{l}-26.3 \\
-26.3 \\
-26.4 \\
-26.5 \\
-26.5 \\
-26.2 \\
-24.1 \\
-23.5 \\
-23.5 \\
-26.1 \\
-26.2 \\
-26.0 \\
-26.1 \\
-26.4 \\
-26.3 \\
-26.5 \\
-26.1 \\
-26.0 \\
-26.2 \\
-26.3 \\
-26.6 \\
-26.0 \\
-25.6 \\
-25.8 \\
-26.1 \\
-26.1 \\
-25.5 \\
-26.1 \\
-26.1 \\
-25.9 \\
-26.1 \\
-24.8 \\
-26.0 \\
-25.8 \\
-25.9 \\
-25.9 \\
-26.1 \\
-23.2 \\
-26.6 \\
-26.2 \\
-25.0 \\
-24.6 \\
-25.5 \\
-25.5\end{array}$ & $\begin{array}{l}6.9 \\
8.2 \\
7.0 \\
8.3 \\
8.6 \\
8.5 \\
7.0 \\
6.8 \\
6.3 \\
7.4 \\
7.2 \\
8.1 \\
7.4 \\
8.3 \\
8.1 \\
8.4 \\
7.6 \\
7.8 \\
7.4 \\
7.5 \\
7.4 \\
8.2 \\
7.5 \\
7.1 \\
8.4 \\
7.3 \\
7.3 \\
8.0 \\
7.9 \\
7.3 \\
7.0 \\
7.7 \\
7.9 \\
8.4 \\
8.2 \\
6.9 \\
7.0 \\
6.7 \\
7.2 \\
7.7 \\
7.7 \\
7.6 \\
7.3 \\
11.9\end{array}$ & \begin{tabular}{|l}
- \\
- \\
- \\
- \\
- \\
- \\
-25.7 \\
-25.1 \\
-25.1 \\
- \\
- \\
- \\
- \\
- \\
- \\
- \\
- \\
- \\
- \\
- \\
- \\
- \\
- \\
- \\
- \\
- \\
- \\
- \\
- \\
- \\
- \\
-26.4 \\
- \\
- \\
- \\
- \\
- \\
-24.8 \\
- \\
- \\
-26.6 \\
-26.2 \\
-27.1 \\
- \\
\end{tabular} & $\begin{array}{l}- \\
- \\
- \\
- \\
- \\
- \\
- \\
- \\
- \\
- \\
- \\
- \\
- \\
- \\
- \\
- \\
- \\
- \\
- \\
- \\
- \\
- \\
- \\
- \\
- \\
- \\
- \\
- \\
- \\
- \\
- \\
- \\
- \\
- \\
- \\
- \\
- \\
- \\
- \\
- \\
- \\
- \\
- \\
- \\
- \\
- \\
- \\
- \\
- \\
- \\
- \\
-\end{array}$ & $\begin{array}{l}3.8 \\
3.9 \\
3.8 \\
4.0 \\
3.9 \\
3.9 \\
3.4 \\
3.4 \\
3.4 \\
3.9 \\
3.9 \\
3.9 \\
3.8 \\
3.9 \\
3.9 \\
3.9 \\
3.9 \\
3.8 \\
3.9 \\
3.9 \\
3.9 \\
3.8 \\
3.9 \\
4.0 \\
4.0 \\
3.8 \\
3.8 \\
3.9 \\
3.9 \\
3.9 \\
3.9 \\
3.4 \\
3.9 \\
4.0 \\
4.0 \\
3.9 \\
3.9 \\
3.4 \\
3.9 \\
3.9 \\
3.4 \\
3.4 \\
3.4 \\
4.0\end{array}$ \\
\hline
\end{tabular}




\begin{tabular}{|c|c|c|c|c|c|c|c|c|c|}
\hline & 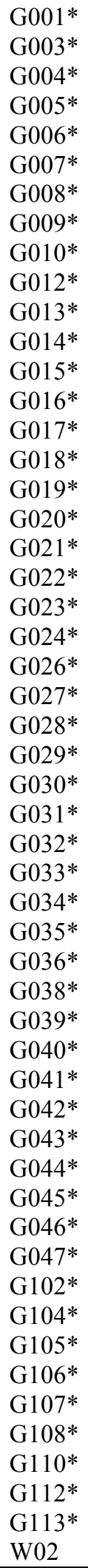 & $\begin{array}{l}\text { F } 2001 \\
\text { F } 2001 \\
\text { F } 2001 \\
\text { F } 2001 \\
\text { F } 2001 \\
\text { F } 2001 \\
\text { F } 2001 \\
\text { W } 2001 \\
\text { | } 2001 \\
\text { W } 2001 \\
\text { W } 2001 \\
\text { W } 2001 \\
\text { W } 2001 \\
\text { W } 2001 \\
\text { F } 2002 \\
\text { F } 2002 \\
\text { F } 2002 \\
\text { F } 2002 \\
\text { F } 2002 \\
\text { F } 2002 \\
\text { F } 2002 \\
\text { F } 2002 \\
\text { F } 2002 \\
\text { F } 2002 \\
\text { F }\end{array}$ & 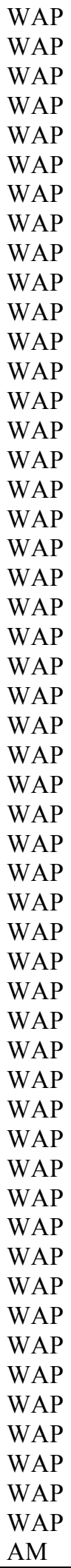 & $\begin{array}{l}\text { Whisker } \\
\text { Whisker } \\
\text { Whisker } \\
\text { Whisker } \\
\text { Whisker } \\
\text { Whisker } \\
\text { Whisker } \\
\text { Whisker } \\
\text { Whisker } \\
\text { Whisker } \\
\text { Whisker } \\
\text { Whisker } \\
\text { Whisker } \\
\text { Whisker } \\
\text { Whisker } \\
\text { Whisker } \\
\text { Whisker } \\
\text { Whisker } \\
\text { Whisker } \\
\text { Whisker } \\
\text { Whisker } \\
\text { Whisker } \\
\text { Whisker } \\
\text { Whisker } \\
\text { Whisker } \\
\text { Whisker } \\
\text { Whisker } \\
\text { Whisker } \\
\text { Whisker } \\
\text { Whisker } \\
\text { Whisker } \\
\text { Whisker } \\
\text { Whisker } \\
\text { Whisker } \\
\text { Whisker } \\
\text { Whisker } \\
\text { Whisker } \\
\text { Whisker } \\
\text { Whisker } \\
\text { Whisker } \\
\text { Whisker } \\
\text { Whisker } \\
\text { Whisker } \\
\text { Whisker }\end{array}$ & $\begin{array}{l}-19.8 \\
-22.1 \\
-21.8 \\
-21.9 \\
-24.1 \\
-21.8 \\
-22.0 \\
-23.4 \\
-22.5 \\
-21.5 \\
-21.3 \\
-21.6 \\
-22.4 \\
-21.1 \\
-21.8 \\
-24.9 \\
-24.7 \\
-24.5 \\
-22.3 \\
-20.9 \\
-24.6 \\
-21.8 \\
-23.6 \\
-22.3 \\
-22.2 \\
-21.6 \\
-22.1 \\
-21.2 \\
-23.2 \\
-21.1 \\
-21.8 \\
-21.6 \\
-21.5 \\
-22.0 \\
-22.9 \\
-23.7 \\
-22.9 \\
-21.6 \\
-22.8 \\
-21.8 \\
-22.0 \\
-21.7 \\
-21.5 \\
-23.8 \\
-22.7 \\
-22.3 \\
-21.9 \\
-23.3 \\
\end{array}$ & $\begin{array}{l}7.1 \\
5.3 \\
6.7 \\
6.6 \\
6.2 \\
6.4 \\
6.8 \\
6.2 \\
6.5 \\
6.8 \\
6.7 \\
7.6 \\
7.3 \\
5.9 \\
6.8 \\
6.5 \\
6.6 \\
6.6 \\
6.7 \\
7.9 \\
6.4 \\
7.2 \\
6.5 \\
6.9 \\
7.1 \\
7.2 \\
6.9 \\
7.5 \\
7.0 \\
7.5 \\
6.7 \\
7.0 \\
7.3 \\
6.9 \\
7.3 \\
6.5 \\
6.7 \\
6.9 \\
7.4 \\
7.1 \\
7.6 \\
7.8 \\
7.1 \\
5.3 \\
6.9 \\
7.1 \\
7.1 \\
6.6 \\
7.5 \\
7.9 \\
5.4 \\
8.5 \\
\end{array}$ & $\begin{array}{l}-21.4 \\
-23.7 \\
-23.4 \\
-23.5 \\
-25.7 \\
-23.4 \\
-23.6 \\
-25.0 \\
-24.1 \\
-23.1 \\
-22.9 \\
-23.2 \\
-24.0 \\
-22.7 \\
-23.4 \\
-26.5 \\
-26.3 \\
-26.1 \\
-23.9 \\
-22.5 \\
-26.2 \\
-23.4 \\
-25.2 \\
-23.9 \\
-23.8 \\
-23.2 \\
-23.7 \\
-22.8 \\
-24.8 \\
-22.7 \\
-23.4 \\
-23.2 \\
-23.1 \\
-23.6 \\
-24.5 \\
-25.3 \\
-24.5 \\
-23.2 \\
-24.4 \\
-23.4 \\
-23.6 \\
-23.3 \\
-23.1 \\
-25.4 \\
-24.3 \\
-23.9 \\
\end{array}$ & 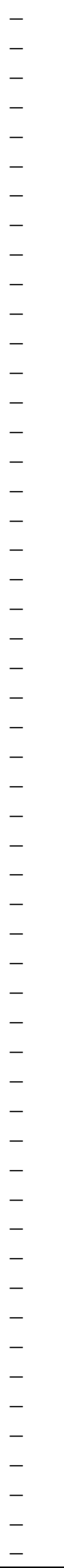 & $\begin{array}{l}3.4 \\
3.5 \\
3.5 \\
3.5 \\
3.5 \\
3.4 \\
3.4 \\
3.4 \\
3.4 \\
3.5 \\
3.5 \\
3.4 \\
3.5 \\
3.5 \\
3.3 \\
3.3 \\
3.3 \\
3.3 \\
3.4 \\
3.4 \\
3.3 \\
3.3 \\
3.3 \\
3.4 \\
3.3 \\
\text { na } \\
3.5 \\
3.4 \\
3.4 \\
3.3 \\
3.3 \\
3.3 \\
3.3 \\
3.3 \\
3.3 \\
3.3 \\
3.4 \\
3.4 \\
3.4 \\
3.4 \\
3.4 \\
3.5 \\
3.4 \\
3.5 \\
3.4 \\
3.4\end{array}$ \\
\hline Weddell & $\begin{array}{l}\text { W01 } \\
\text { W02 } \\
\text { W04 }\end{array}$ & $\begin{array}{l}\mathrm{Su} 2010 / 11 \\
\mathrm{Su} 2010 / 11 \\
\mathrm{Su} 2010 / 11\end{array}$ & $\begin{array}{l}\text { AM } \\
\text { AM } \\
\text { AM }\end{array}$ & $\begin{array}{l}\text { Hair } \\
\text { Hair } \\
\text { Clot }\end{array}$ & $\begin{array}{l}-23.2 \\
-23.2 \\
-24.8\end{array}$ & $\begin{array}{l}13.3 \\
12.6 \\
12.2\end{array}$ & $\begin{array}{l}-24.6 \\
-24.6 \\
-\end{array}$ & $\begin{array}{l}12.8 \\
12.1 \\
-\end{array}$ & $\begin{array}{l}3.5 \\
3.5 \\
3.9\end{array}$ \\
\hline
\end{tabular}




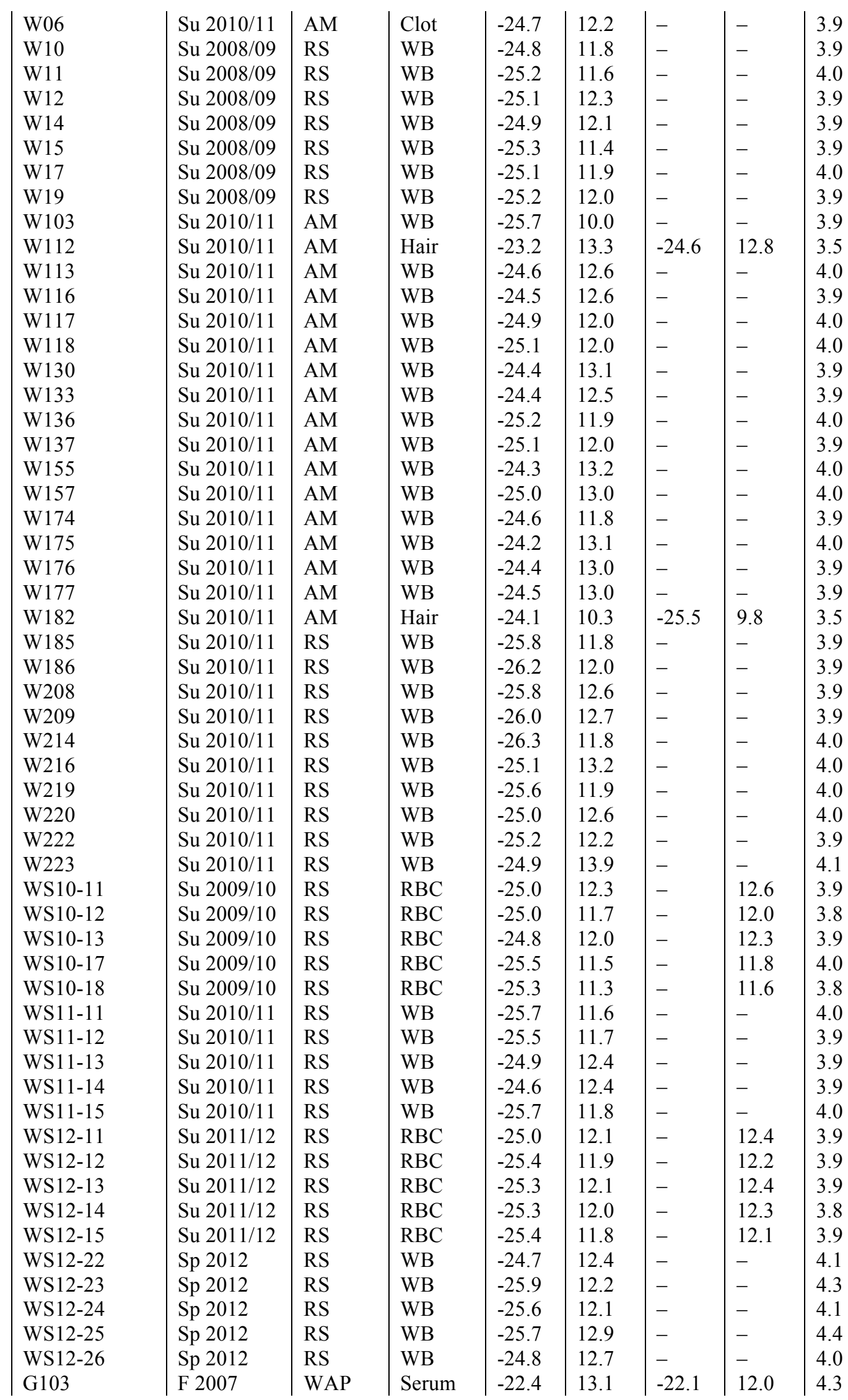




\begin{tabular}{|c|c|c|c|c|c|c|c|c|}
\hline G111 & F 2007 & WAP & Plasma & -22.8 & 12.3 & -22.2 & 11.6 & 4.2 \\
\hline LW11-03 & Su 2010/11 & $\mathrm{RS}$ & WB & -24.3 & 12.2 & - & - & 3.9 \\
\hline LW11-05 & Su 2010/11 & $\mathrm{RS}$ & WB & -25.7 & 12.2 & - & - & 3.9 \\
\hline LW11-06 & Su 2010/11 & $\mathrm{RS}$ & WB & -25.8 & 12.0 & - & - & 3.9 \\
\hline LW11-07 & Su 2010/11 & $\mathrm{RS}$ & WB & -25.6 & 12.2 & - & - & 3.9 \\
\hline LW11-08 & Su 2010/11 & $\mathrm{RS}$ & WB & -24.9 & 12.3 & - & - & 3.9 \\
\hline LW11-09 & Su 2010/11 & $\mathrm{RS}$ & WB & -25.0 & 12.3 & - & - & 3.9 \\
\hline LW11-10 & Su 2010/11 & $\mathrm{RS}$ & WB & -25.7 & 11.9 & - & - & 3.9 \\
\hline LW11-11 & $\mathrm{Su} 2010 / 11$ & $\mathrm{RS}$ & WB & -24.1 & 13.1 & - & - & 3.9 \\
\hline LW11-12 & Su 2010/11 & RS & WB & -25.8 & 12.0 & - & - & 3.9 \\
\hline LW11-13 & Su 2010/11 & $\mathrm{RS}$ & WB & -25.3 & 12.1 & - & - & 3.9 \\
\hline LW11-14 & Su 2010/11 & $\mathrm{RS}$ & WB & -25.5 & 12.1 & - & - & 3.9 \\
\hline LW11-15 & $\mathrm{Su} 2010 / 11$ & $\mathrm{RS}$ & WB & -25.8 & 13.0 & - & - & 4.1 \\
\hline LW15-01 & Sp 2015 & RS & WB & -25.8 & 12.1 & - & - & 4.2 \\
\hline LW15-02 & Sp 2015 & RS & WB & -25.2 & 12.1 & - & - & 3.9 \\
\hline LW15-03 & Sp 2015 & $\mathrm{RS}$ & WB & -25.3 & 12.1 & - & - & 3.9 \\
\hline LW15-04 & Sp 2015 & $\mathrm{RS}$ & WB & -25.3 & 12.0 & - & - & 3.9 \\
\hline LW15-05 & Sp 2015 & $\mathrm{RS}$ & WB & -25.3 & 12.2 & - & - & 3.9 \\
\hline LW15-06 & Sp 2015 & RS & WB & -25.2 & 11.8 & - & - & 4.0 \\
\hline LW15-07 & Sp 2015 & $\mathrm{RS}$ & WB & -25.3 & 12.2 & - & - & 4.0 \\
\hline LW15-08 & Sp 2015 & $\mathrm{RS}$ & WB & -25.3 & 11.9 & - & - & 3.9 \\
\hline LW15-09 & Sp 2015 & $\mathrm{RS}$ & WB & -25.3 & 12.0 & - & - & 3.9 \\
\hline LW15-10 & Sp 2015 & RS & WB & -25.1 & 12.2 & - & - & 3.9 \\
\hline LW15-11 & Sp 2015 & $\mathrm{RS}$ & WB & -25.3 & 12.2 & - & - & 3.9 \\
\hline LW15-12 & Sp 2015 & $\mathrm{RS}$ & WB & -25.2 & 11.9 & - & - & 4.0 \\
\hline W006 & Su 2009/10 & WAP & Whisker & -22.6 & 10.9 & -24.0 & 10.4 & 3.4 \\
\hline W013 & Su $2009 / 10$ & WAP & Whisker & -21.9 & 12.1 & -23.3 & 11.6 & 3.4 \\
\hline WS10-01** & Su 2009/10 & $\mathrm{RS}$ & Whisker & -23.3 & 12.9 & -24.7 & 12.4 & na \\
\hline WS10-02** & Su 2009/10 & $\mathrm{RS}$ & Whisker & -22.8 & 14.5 & -24.2 & 14.0 & na \\
\hline WS10-03** & Su 2009/10 & $\mathrm{RS}$ & Whisker & -23.5 & 13.0 & -24.9 & 12.5 & na \\
\hline WS10-04** & Su 2009/10 & $\mathrm{RS}$ & Whisker & -23.0 & 12.5 & -24.4 & 12.0 & na \\
\hline WS10-05** & Su 2009/10 & RS & Whisker & -22.9 & 12.4 & -24.3 & 11.9 & na \\
\hline WS10-06** & Su 2009/10 & $\mathrm{RS}$ & Whisker & -24.6 & 13.3 & -26.0 & 12.8 & na \\
\hline WS10-07** & Su 2009/10 & $\mathrm{RS}$ & Whisker & -23.3 & 12.8 & -24.7 & 12.3 & na \\
\hline WS10-19** & Su 2009/10 & $\mathrm{RS}$ & Whisker & -23.8 & 12.5 & -25.2 & 12.0 & na \\
\hline WS10-20** & Su 2009/10 & $\mathrm{RS}$ & Whisker & -23.8 & 12.9 & -25.2 & 12.4 & na \\
\hline WS10-21** & Su $2009 / 10$ & $\mathrm{RS}$ & Whisker & -22.9 & 12.5 & -24.3 & 12.0 & na \\
\hline WS10-22** & Su $2009 / 10$ & RS & Whisker & -23.1 & 12.4 & -24.5 & 11.9 & na \\
\hline WS11-03** & Su 2010/11 & $\mathrm{RS}$ & Whisker & -23.4 & 12.6 & -24.8 & 12.1 & na \\
\hline WS11-04** & Su 2010/11 & $\mathrm{RS}$ & Whisker & -23.5 & 12.8 & -24.9 & 12.3 & na \\
\hline WS11-05** & Su 2010/11 & $\mathrm{RS}$ & Whisker & -23.3 & 13.5 & -24.7 & 13.0 & na \\
\hline WS11-06** & Su 2010/11 & $\mathrm{RS}$ & Whisker & -23.5 & 14.0 & -24.9 & 13.5 & na \\
\hline WS11-08** & Su 2010/11 & RS & Whisker & -23.3 & 13.8 & -24.7 & 13.3 & na \\
\hline WS11-09** & Su 2010/11 & RS & Whisker & -24.7 & 14.2 & -26.1 & 13.7 & na \\
\hline WS11-17** & Su 2010/11 & $\mathrm{RS}$ & Whisker & -23.4 & 12.5 & -24.8 & 12.0 & na \\
\hline WS11-18** & Su 2010/11 & $\mathrm{RS}$ & Whisker & -23.6 & 12.9 & -25.0 & 12.4 & na \\
\hline WS11-19** & Su 2010/11 & $\mathrm{RS}$ & Whisker & -23.5 & 13.4 & -24.9 & 12.9 & na \\
\hline WS11-21** & Su 2010/11 & $\mathrm{RS}$ & Whisker & -24.1 & 12.5 & -25.5 & 12.0 & na \\
\hline WS11-37** & Su 2011/12 & $\mathrm{RS}$ & Whisker & -23.0 & 12.7 & -24.4 & 12.2 & na \\
\hline WS11-38** & Su 2011/12 & $\mathrm{RS}$ & Whisker & -23.1 & 13.5 & -24.5 & 13.0 & na \\
\hline WS11-39** & Su 2011/12 & RS & Whisker & -23.5 & 12.6 & -24.9 & 12.1 & na \\
\hline WS11-40** & Su 2011/12 & $\mathrm{RS}$ & Whisker & -23.7 & 12.8 & -25.1 & 12.3 & na \\
\hline WS11-41** & Su 2011/12 & $\mathrm{RS}$ & Whisker & -23.4 & 13.6 & -24.8 & 13.1 & na \\
\hline
\end{tabular}


Antarctic Seal Foraging Ecology

\begin{tabular}{|c|c|c|c|c|c|c|c|c|c|}
\hline & WS12-01** & Su 2011/12 & RS & Whisker & -24.1 & 12.8 & -25.5 & 12.3 & na \\
\hline & WS12-02** & Su 2011/12 & RS & Whisker & -23.7 & 12.6 & -25.1 & 12.1 & na \\
\hline & WS12-04** & Su 2011/12 & RS & Whisker & -23.3 & 12.7 & -24.7 & 12.2 & na \\
\hline & WS12-05** & Su 2011/12 & RS & Whisker & -23.2 & 13.2 & -24.6 & 12.7 & na \\
\hline & WS12-06** & Su 2011/12 & RS & Whisker & -22.7 & 13.4 & -24.1 & 12.9 & na \\
\hline & WS12-07** & Su 2011/12 & RS & Whisker & -23.2 & 13.8 & -24.6 & 13.3 & na \\
\hline & WS12-08** & Su 2011/12 & RS & Whisker & -22.6 & 13.7 & -24.0 & 13.2 & na \\
\hline & WS12-09** & Su 2011/12 & RS & Whisker & -22.8 & 13.6 & -24.2 & 13.1 & na \\
\hline & WS12-10** & Su 2011/12 & RS & Whisker & -23.6 & 13.3 & -25.0 & 12.8 & na \\
\hline & WS12-16** & Su 2011/12 & RS & Whisker & -24.2 & 12.7 & -25.6 & 12.2 & na \\
\hline & WS12-17** & Su 2011/12 & RS & Whisker & -23.8 & 12.4 & -25.2 & 11.9 & na \\
\hline & WS12-19** & Su $2011 / 12$ & RS & Whisker & -23.4 & 13.6 & -24.8 & 13.1 & na \\
\hline & WS $12-20 * *$ & Su 2011/12 & RS & Whisker & -23.4 & 13.2 & -24.8 & 12.7 & na \\
\hline Ross & R01 & Su 2008/09 & AM & WB & -23.2 & 8.5 & - & - & 3.9 \\
\hline & $\mathrm{R} 101$ & Su 2010/11 & $\mathrm{AM}$ & WB & -23.9 & 9.6 & - & - & 3.9 \\
\hline & R102 & Su $2010 / 11$ & $\mathrm{AM}$ & WB & -23.6 & 9.0 & - & - & 4.0 \\
\hline & R103 & Su 2010/11 & $\mathrm{AM}$ & WB & -24.0 & 9.0 & - & - & 4.0 \\
\hline & R104 & Su 2010/11 & $\mathrm{AM}$ & WB & -23.7 & 9.2 & - & - & 4.0 \\
\hline & R105 & Su 2010/11 & $\mathrm{AM}$ & WB & -23.6 & 9.2 & - & - & 4.0 \\
\hline & R106 & Su 2010/11 & $\mathrm{AM}$ & WB & -24.1 & 8.8 & - & - & 3.9 \\
\hline & $\mathrm{R} 107$ & Su 2010/11 & $\mathrm{AM}$ & WB & -23.6 & 8.8 & - & - & 3.9 \\
\hline & R108 & Su $2010 / 11$ & AM & WB & -24.6 & 10.0 & - & - & 4.0 \\
\hline & R109 & Su 2010/11 & $\mathrm{AM}$ & WB & -23.9 & 9.0 & - & - & 4.0 \\
\hline & $\mathrm{R} 110$ & Su 2010/11 & $\mathrm{AM}$ & Hair & -23.0 & 10.0 & -24.3 & 8.8 & 3.5 \\
\hline & R111 & $\mathrm{Su} 2010 / 11$ & AM & WB & -23.6 & 8.8 & - & - & 4.0 \\
\hline & $\mathrm{R} 112$ & Su 2010/11 & $\mathrm{AM}$ & WB & -23.8 & 9.7 & - & - & 3.9 \\
\hline & R113 & Su $2010 / 11$ & $\mathrm{AM}$ & WB & -23.7 & 9.0 & - & - & 4.0 \\
\hline & $\mathrm{R} 114$ & $\mathrm{Su} 2010 / 11$ & RS & WB & -23.8 & 8.6 & - & - & 4.0 \\
\hline
\end{tabular}




\section{Antarctic Seal Foraging Ecology}

Table S8. Amino acid $\delta^{15} \mathrm{~N}$ values for crabeater, Ross, and Weddell seals. Values are reported as the mean \pm one standard deviation for the injections on the GC/C/IRMS. For crabeater seals, whole blood (C06, C44, C177) and plasma (G112, G105, and G110) samples were analyzed. All Ross seal samples analyzed for amino acid $\delta^{15} \mathrm{~N}$ values were whole blood. For Weddell seals, whole blood (W185, W220, and WS11-11), plasma (G111), and sample from the first segment nearest the whisker base, 0.0-0.5 cm, (W006 and W013) were used for CSI-AA. Abbreviation: na, not available.

\begin{tabular}{|c|c|c|c|c|c|}
\hline Species & Sample ID & Region & Amino Acid & Injections & $\delta^{15} \mathrm{~N}(\%)$ \\
\hline \multirow[t]{49}{*}{ Crabeater } & $\mathrm{C} 06$ & AM & Alanine & 3 & $13.7 \pm 0.3$ \\
\hline & $\mathrm{C} 06$ & AM & Glycine & 3 & $8.5 \pm 0.1$ \\
\hline & $\mathrm{C} 06$ & AM & Threonine & 3 & $-21.9 \pm 0.6$ \\
\hline & $\mathrm{C} 06$ & AM & Serine & 3 & $7.0 \pm 0.5$ \\
\hline & $\mathrm{C} 06$ & AM & Valine & 3 & $14.9 \pm 0.3$ \\
\hline & $\mathrm{C} 06$ & AM & Leucine & 3 & $13.9 \pm 0.2$ \\
\hline & $\mathrm{C} 06$ & AM & Isoleucine & 3 & $12.8 \pm 0.2$ \\
\hline & $\mathrm{C} 06$ & AM & Proline & 3 & $15.7 \pm 0.4$ \\
\hline & $\mathrm{C} 06$ & AM & Aspartic & 3 & $11.0 \pm 0.3$ \\
\hline & $\mathrm{C} 06$ & AM & Glutamic acid & 3 & $15.1 \pm 0.4$ \\
\hline & $\mathrm{C} 06$ & AM & Phenylalanine & 3 & $6.8 \pm 0.3$ \\
\hline & $\mathrm{C} 06$ & AM & Lysine & 3 & $5.5 \pm 0.6$ \\
\hline & G112 & WAP & Alanine & 3 & $12.0 \pm 0.7$ \\
\hline & G112 & WAP & Glycine & 3 & $0.6 \pm 0.1$ \\
\hline & G112 & WAP & Threonine & 3 & $-20.7 \pm 0.1$ \\
\hline & G112 & WAP & Serine & 3 & $1.9 \pm 0.2$ \\
\hline & G112 & WAP & Valine & 3 & $13.5 \pm 0.2$ \\
\hline & G112 & WAP & Leucine & 3 & $11.8 \pm 0.6$ \\
\hline & G112 & WAP & Isoleucine & 3 & $11.6 \pm 1.0$ \\
\hline & G112 & WAP & Proline & 3 & $15.5 \pm 0.6$ \\
\hline & G112 & WAP & Aspartic & 3 & $9.9 \pm 0.2$ \\
\hline & G112 & WAP & Glutamic acid & 3 & $15.0 \pm 0.4$ \\
\hline & G112 & WAP & Phenylalanine & 3 & $4.3 \pm 0.1$ \\
\hline & G112 & WAP & Lysine & 2 & $4.5 \pm 0.2$ \\
\hline & $\mathrm{C} 44$ & AM & Alanine & 3 & $14.3 \pm 0.4$ \\
\hline & $\mathrm{C} 44$ & AM & Glycine & 3 & $4.7 \pm 0.4$ \\
\hline & $\mathrm{C} 44$ & AM & Threonine & 3 & $-25.4 \pm 0.4$ \\
\hline & $\mathrm{C} 44$ & AM & Serine & 3 & $4.2 \pm 0.2$ \\
\hline & $\mathrm{C} 44$ & AM & Valine & 3 & $15.1 \pm 0.5$ \\
\hline & $\mathrm{C} 44$ & AM & Leucine & 3 & $13.4 \pm 0.5$ \\
\hline & $\mathrm{C} 44$ & AM & Isoleucine & 3 & $12.2 \pm 0.1$ \\
\hline & $\mathrm{C} 44$ & AM & Proline & 3 & $14.7 \pm 0.3$ \\
\hline & $\mathrm{C} 44$ & AM & Aspartic & 3 & $9.3 \pm 0.2$ \\
\hline & $\mathrm{C} 44$ & AM & Glutamic acid & 3 & $15.0 \pm 0.2$ \\
\hline & $\mathrm{C} 44$ & AM & Phenylalanine & 3 & $5.8 \pm 0.2$ \\
\hline & $\mathrm{C} 44$ & AM & Lysine & 3 & $4.9 \pm 0.3$ \\
\hline & G105 & WAP & Alanine & 3 & $13.3 \pm 0.4$ \\
\hline & G105 & WAP & Glycine & 3 & $1.6 \pm 0.3$ \\
\hline & G105 & WAP & Threonine & 3 & $-19.6 \pm 0.4$ \\
\hline & G105 & WAP & Serine & 3 & $2.5 \pm 0.3$ \\
\hline & G105 & WAP & Valine & 3 & $14.4 \pm 0.5$ \\
\hline & G105 & WAP & Leucine & 3 & $12.7 \pm 0.1$ \\
\hline & G105 & WAP & Isoleucine & 3 & $11.5 \pm 0.6$ \\
\hline & G105 & WAP & Proline & 3 & $16.5 \pm 0.5$ \\
\hline & G105 & WAP & Aspartic & 3 & $10.4 \pm 0.0$ \\
\hline & G105 & WAP & Glutamic acid & 3 & $15.2 \pm 0.3$ \\
\hline & G105 & WAP & Phenylalanine & 3 & $4.7 \pm 0.2$ \\
\hline & G105 & WAP & Lysine & 3 & $5.3 \pm 0.5$ \\
\hline & $\mathrm{C} 177$ & $\mathrm{RS}$ & Alanine & 4 & $14.6 \pm 0.4$ \\
\hline
\end{tabular}




\begin{tabular}{|c|c|c|c|c|c|}
\hline & $\begin{array}{l}\mathrm{C} 177 \\
\mathrm{C} 177 \\
\mathrm{C} 177 \\
\mathrm{C} 177 \\
\mathrm{C} 177 \\
\mathrm{C} 177 \\
\mathrm{C} 177 \\
\mathrm{C} 177 \\
\mathrm{C} 177 \\
\mathrm{C} 177 \\
\mathrm{C} 177\end{array}$ & $\begin{array}{l}\text { RS } \\
\text { RS } \\
\text { RS } \\
\text { RS } \\
\text { RS } \\
\text { RS } \\
\text { RS } \\
\text { RS } \\
\text { RS } \\
\text { RS } \\
\text { RS }\end{array}$ & $\begin{array}{c}\text { Glycine } \\
\text { Threonine } \\
\text { Serine } \\
\text { Valine } \\
\text { Leucine } \\
\text { Isoleucine } \\
\text { Proline } \\
\text { Aspartic } \\
\text { Glutamic acid } \\
\text { Phenylalanine } \\
\text { Lysine }\end{array}$ & $\begin{array}{l}4 \\
4 \\
4 \\
4 \\
4 \\
4 \\
4 \\
4 \\
4 \\
4 \\
4\end{array}$ & $\begin{array}{c}3.9 \pm 0.4 \\
-26.1 \pm 0.8 \\
5.2 \pm 0.6 \\
15.7 \pm 0.8 \\
14.4 \pm 0.5 \\
12.6 \pm 0.7 \\
15.7 \pm 0.5 \\
9.8 \pm 0.1 \\
14.4 \pm 0.3 \\
5.4 \pm 0.4 \\
5.1 \pm 0.5\end{array}$ \\
\hline & $\begin{array}{l}\text { G110 } \\
\text { G110 } \\
\text { G110 } \\
\text { G110 } \\
\text { G110 } \\
\text { G110 } \\
\text { G110 } \\
\text { G110 } \\
\text { G110 } \\
\text { G110 } \\
\text { G110 } \\
\text { G110 }\end{array}$ & $\begin{array}{l}\text { WAP } \\
\text { WAP } \\
\text { WAP } \\
\text { WAP } \\
\text { WAP } \\
\text { WAP } \\
\text { WAP } \\
\text { WAP } \\
\text { WAP } \\
\text { WAP } \\
\text { WAP } \\
\text { WAP }\end{array}$ & $\begin{array}{c}\text { Alanine } \\
\text { Glycine } \\
\text { Threonine } \\
\text { Serine } \\
\text { Valine } \\
\text { Leucine } \\
\text { Isoleucine } \\
\text { Proline } \\
\text { Aspartic } \\
\text { Glutamic acid } \\
\text { Phenylalanine } \\
\text { Lysine }\end{array}$ & $\begin{array}{l}3 \\
3 \\
3 \\
3 \\
3 \\
3 \\
3 \\
3 \\
3 \\
3 \\
3 \\
3\end{array}$ & $\begin{array}{c}13.4 \pm 0.1 \\
3.4 \pm 0.1 \\
-23.4 \pm 0.3 \\
4.7 \pm 0.5 \\
15.8 \pm 0.3 \\
13.5 \pm 0.2 \\
12.3 \pm 0.4 \\
15.8 \pm 0.3 \\
10.4 \pm 0.4 \\
14.8 \pm 0.4 \\
4.1 \pm 0.5 \\
5.0 \pm 0.2\end{array}$ \\
\hline Weddell & $\begin{array}{l}\text { G111 } \\
\text { G111 } \\
\text { G111 } \\
\text { G111 } \\
\text { G111 } \\
\text { G111 } \\
\text { G111 } \\
\text { G111 } \\
\text { G111 } \\
\text { G111 } \\
\text { G111 } \\
\text { G111 }\end{array}$ & $\begin{array}{l}\text { WAP } \\
\text { WAP } \\
\text { WAP } \\
\text { WAP } \\
\text { WAP } \\
\text { WAP } \\
\text { WAP } \\
\text { WAP } \\
\text { WAP } \\
\text { WAP } \\
\text { WAP } \\
\text { WAP }\end{array}$ & $\begin{array}{c}\text { Alanine } \\
\text { Glycine } \\
\text { Threonine } \\
\text { Serine } \\
\text { Valine } \\
\text { Leucine } \\
\text { Isoleucine } \\
\text { Proline } \\
\text { Aspartic } \\
\text { Glutamic acid } \\
\text { Phenylalanine } \\
\text { Lysine }\end{array}$ & $\begin{array}{l}3 \\
3 \\
3 \\
3 \\
3 \\
3 \\
3 \\
3 \\
3 \\
3 \\
3 \\
3\end{array}$ & $\begin{array}{c}18.9 \pm 0.4 \\
5.0 \pm 0.4 \\
-22.1 \pm 0.6 \\
8.6 \pm 0.1 \\
22.9 \pm 0.5 \\
20.8 \pm 0.4 \\
19.6 \pm 0.6 \\
20.8 \pm 0.9 \\
16.7 \pm 0.5 \\
20.4 \pm 0.5 \\
5.3 \pm 0.4 \\
6.7 \pm 0.4\end{array}$ \\
\hline & $\begin{array}{l}\text { W006 } \\
\text { W006 } \\
\text { W006 } \\
\text { W006 } \\
\text { W006 } \\
\text { W006 } \\
\text { W006 } \\
\text { W006 } \\
\text { W006 } \\
\text { W006 } \\
\text { W006 } \\
\text { W006 }\end{array}$ & $\begin{array}{l}\text { WAP } \\
\text { WAP } \\
\text { WAP } \\
\text { WAP } \\
\text { WAP } \\
\text { WAP } \\
\text { WAP } \\
\text { WAP } \\
\text { WAP } \\
\text { WAP } \\
\text { WAP } \\
\text { WAP }\end{array}$ & $\begin{array}{c}\text { Alanine } \\
\text { Glycine } \\
\text { Threonine } \\
\text { Serine } \\
\text { Valine } \\
\text { Leucine } \\
\text { Isoleucine } \\
\text { Proline } \\
\text { Aspartic } \\
\text { Glutamic acid } \\
\text { Phenylalanine } \\
\text { Lysine }\end{array}$ & $\begin{array}{l}3 \\
3 \\
3 \\
3 \\
3 \\
3 \\
3 \\
3 \\
3 \\
3 \\
3 \\
1\end{array}$ & $\begin{array}{c}20.7 \pm 0.2 \\
2.1 \pm 0.1 \\
-29.4 \pm 0.3 \\
6.7 \pm 0.2 \\
24.0 \pm 0.5 \\
21.7 \pm 0.4 \\
21.4 \pm 0.9 \\
18.0 \pm 0.1 \\
12.8 \pm 0.1 \\
20.8 \pm 0.2 \\
5.9 \pm 0.5 \\
3.1\end{array}$ \\
\hline & $\begin{array}{l}\text { W013 } \\
\text { W013 } \\
\text { W013 } \\
\text { W013 } \\
\text { W013 } \\
\text { W013 } \\
\text { W013 } \\
\text { W013 } \\
\text { W013 }\end{array}$ & $\begin{array}{l}\text { WAP } \\
\text { WAP } \\
\text { WAP } \\
\text { WAP } \\
\text { WAP } \\
\text { WAP } \\
\text { WAP } \\
\text { WAP } \\
\text { WAP }\end{array}$ & $\begin{array}{c}\text { Alanine } \\
\text { Glycine } \\
\text { Threonine } \\
\text { Serine } \\
\text { Valine } \\
\text { Leucine } \\
\text { Isoleucine } \\
\text { Proline } \\
\text { Aspartic }\end{array}$ & $\begin{array}{l}3 \\
3 \\
3 \\
3 \\
3 \\
3 \\
3 \\
3 \\
3\end{array}$ & $\begin{array}{c}22.1 \pm 0.1 \\
2.3 \pm 0.1 \\
-31.9 \pm 0.3 \\
8.0 \pm 0.2 \\
25.5 \pm 0.5 \\
23.5 \pm 0.1 \\
24.0 \pm 0.2 \\
18.5 \pm 0.2 \\
14.2 \pm 0.1\end{array}$ \\
\hline
\end{tabular}




\begin{tabular}{|c|c|c|c|c|c|}
\hline & $\begin{array}{l}\text { W013 } \\
\text { W013 } \\
\text { W013 }\end{array}$ & $\begin{array}{l}\text { WAP } \\
\text { WAP } \\
\text { WAP }\end{array}$ & $\begin{array}{c}\text { Glutamic acid } \\
\text { Phenylalanine } \\
\text { Lysine }\end{array}$ & $\begin{array}{l}3 \\
3 \\
2\end{array}$ & $\begin{array}{c}22.2 \pm 0.2 \\
5.9 \pm 0.1 \\
3.6 \pm 0.8\end{array}$ \\
\hline & W185 & $\mathrm{RS}$ & Alanine & 3 & $22.8 \pm 0.1$ \\
\hline & W185 & $\mathrm{RS}$ & Glycine & 3 & $6.9 \pm 0.9$ \\
\hline & W185 & $\mathrm{RS}$ & Threonine & 3 & $-29.9 \pm 0.4$ \\
\hline & W185 & $\mathrm{RS}$ & Serine & 3 & $9.0 \pm 0.5$ \\
\hline & W185 & $\mathrm{RS}$ & Valine & 3 & $24.2 \pm 0.4$ \\
\hline & W185 & $\mathrm{RS}$ & Leucine & 3 & $22.6 \pm 0.4$ \\
\hline & W185 & $\mathrm{RS}$ & Isoleucine & 3 & $21.7 \pm 0.6$ \\
\hline & W185 & $\mathrm{RS}$ & Proline & 3 & $21.0 \pm 0.1$ \\
\hline & W185 & $\mathrm{RS}$ & Aspartic & 3 & $17.2 \pm 0.2$ \\
\hline & W185 & $\mathrm{RS}$ & Glutamic acid & 3 & $20.7 \pm 0.4$ \\
\hline & W185 & $\mathrm{RS}$ & Phenylalanine & 3 & $5.0 \pm 0.0$ \\
\hline & W185 & RS & Lysine & 3 & $5.4 \pm 0.4$ \\
\hline & W220 & $\mathrm{RS}$ & Alanine & 3 & $23.1 \pm 0.1$ \\
\hline & W220 & $\mathrm{RS}$ & Glycine & 3 & $9.4 \pm 0.3$ \\
\hline & W220 & $\mathrm{RS}$ & Threonine & 3 & $-27.9 \pm 0.3$ \\
\hline & W220 & $\mathrm{RS}$ & Serine & 3 & $10.9 \pm 0.3$ \\
\hline & W220 & $\mathrm{RS}$ & Valine & 3 & $25.0 \pm 0.6$ \\
\hline & W220 & $\mathrm{RS}$ & Leucine & 3 & $23.3 \pm 0.2$ \\
\hline & W220 & $\mathrm{RS}$ & Isoleucine & 3 & $22.8 \pm 1.0$ \\
\hline & W220 & $\mathrm{RS}$ & Proline & 3 & $21.3 \pm 0.7$ \\
\hline & W220 & $\mathrm{RS}$ & Aspartic & 3 & $18.6 \pm 0.1$ \\
\hline & W220 & $\mathrm{RS}$ & Glutamic acid & 3 & $22.3 \pm 0.2$ \\
\hline & W220 & $\mathrm{RS}$ & Phenylalanine & 3 & $6.4 \pm 0.1$ \\
\hline & W220 & $\mathrm{RS}$ & Lysine & 3 & $6.8 \pm 0.8$ \\
\hline & WS11-11 & $\mathrm{RS}$ & Alanine & 3 & $22.5 \pm 0.1$ \\
\hline & WS11-11 & $\mathrm{RS}$ & Glycine & 3 & $7.0 \pm 0.9$ \\
\hline & WS11-11 & $\mathrm{RS}$ & Threonine & 3 & $-28.3 \pm 0.3$ \\
\hline & WS11-11 & $\mathrm{RS}$ & Serine & 3 & $9.2 \pm 0.5$ \\
\hline & WS11-11 & $\mathrm{RS}$ & Valine & 3 & $24.6 \pm 0.3$ \\
\hline & WS11-11 & $\mathrm{RS}$ & Leucine & 3 & $22.6 \pm 0.3$ \\
\hline & WS11-11 & $\mathrm{RS}$ & Isoleucine & 3 & $21.7 \pm 0.9$ \\
\hline & WS11-11 & $\mathrm{RS}$ & Proline & 3 & $20.4 \pm 0.9$ \\
\hline & WS11-11 & $\mathrm{RS}$ & Aspartic & 3 & $17.5 \pm 0.5$ \\
\hline & WS11-11 & $\mathrm{RS}$ & Glutamic acid & 3 & $21.5 \pm 0.3$ \\
\hline & WS11-11 & $\mathrm{RS}$ & Phenylalanine & 3 & $5.6 \pm 0.2$ \\
\hline & WS11-11 & $\mathrm{RS}$ & Lysine & 3 & $5.8 \pm 0.5$ \\
\hline Ross & R101 & $\mathrm{AM}$ & Alanine & 3 & $20.3 \pm 0.3$ \\
\hline & R101 & $\mathrm{AM}$ & Glycine & 3 & $2.9 \pm 0.2$ \\
\hline & R101 & $\mathrm{AM}$ & Threonine & 3 & $-29.2 \pm 0.2$ \\
\hline & R101 & $\mathrm{AM}$ & Serine & 3 & $4.4 \pm 0.7$ \\
\hline & R101 & $\mathrm{AM}$ & Valine & 3 & $21.5 \pm 0.1$ \\
\hline & $\mathrm{R} 101$ & $\mathrm{AM}$ & Leucine & 3 & $19.9 \pm 0.3$ \\
\hline & $\mathrm{R} 101$ & $\mathrm{AM}$ & Isoleucine & 3 & $20.1 \pm 1.0$ \\
\hline & $\mathrm{R} 101$ & $\mathrm{AM}$ & Proline & 3 & $17.3 \pm 0.3$ \\
\hline & R101 & $\mathrm{AM}$ & Aspartic & 3 & $15.9 \pm 0.1$ \\
\hline & $\mathrm{R} 101$ & $\mathrm{AM}$ & Glutamic acid & 3 & $18.3 \pm 0.7$ \\
\hline & $\mathrm{R} 101$ & $\mathrm{AM}$ & Phenylalanine & 3 & $2.5 \pm 0.2$ \\
\hline & $\mathrm{R} 101$ & AM & Lysine & na & $\mathrm{Na}$ \\
\hline & R103 & $\mathrm{AM}$ & Alanine & 3 & $18.5 \pm 0.3$ \\
\hline & R103 & $\mathrm{AM}$ & Glycine & 3 & $5.1 \pm 0.4$ \\
\hline & R103 & $\mathrm{AM}$ & Threonine & 3 & $-27.4 \pm 0.7$ \\
\hline & R103 & AM & Serine & 3 & $5.4 \pm 0.8$ \\
\hline & R103 & $\mathrm{AM}$ & Valine & 3 & $20.0 \pm 0.4$ \\
\hline
\end{tabular}




\begin{tabular}{|c|c|c|c|c|}
\hline $\begin{array}{l}\text { R103 } \\
\text { R103 } \\
\text { R103 } \\
\text { R103 } \\
\text { R103 } \\
\text { R103 } \\
\text { R103 }\end{array}$ & $\begin{array}{l}\text { AM } \\
\text { AM } \\
\text { AM } \\
\text { AM } \\
\text { AM } \\
\text { AM } \\
\text { AM }\end{array}$ & $\begin{array}{c}\text { Leucine } \\
\text { Isoleucine } \\
\text { Proline } \\
\text { Aspartic } \\
\text { Glutamic acid } \\
\text { Phenylalanine } \\
\text { Lysine }\end{array}$ & $\begin{array}{l}3 \\
3 \\
3 \\
3 \\
3 \\
3 \\
3\end{array}$ & $\begin{array}{c}18.6 \pm 0.3 \\
15.7 \pm 0.6 \\
16.9 \pm 0.6 \\
13.9 \pm 0.2 \\
17.2 \pm 0.6 \\
2.6 \pm 0.4 \\
1.8 \pm 0.4 \\
\end{array}$ \\
\hline $\begin{array}{l}\text { R106 } \\
\text { R106 } \\
\text { R106 } \\
\text { R106 } \\
\text { R106 } \\
\text { R106 } \\
\text { R106 } \\
\text { R106 } \\
\text { R106 } \\
\text { R106 } \\
\text { R106 } \\
\text { R106 }\end{array}$ & $\begin{array}{l}\text { AM } \\
\text { AM } \\
\text { AM } \\
\text { AM } \\
\text { AM } \\
\text { AM } \\
\text { AM } \\
\text { AM } \\
\text { AM } \\
\text { AM } \\
\text { AM } \\
\text { AM }\end{array}$ & $\begin{array}{c}\text { Alanine } \\
\text { Glycine } \\
\text { Threonine } \\
\text { Serine } \\
\text { Valine } \\
\text { Leucine } \\
\text { Isoleucine } \\
\text { Proline } \\
\text { Aspartic } \\
\text { Glutamic acid } \\
\text { Phenylalanine } \\
\text { Lysine }\end{array}$ & $\begin{array}{l}3 \\
3 \\
3 \\
3 \\
3 \\
3 \\
3 \\
3 \\
3 \\
3 \\
3 \\
3\end{array}$ & $\begin{array}{c}18.8 \pm 0.1 \\
5.7 \pm 0.3 \\
-27.5 \pm 0.3 \\
5.8 \pm 0.4 \\
19.3 \pm 0.4 \\
17.9 \pm 0.3 \\
18.8 \pm 0.7 \\
17.3 \pm 0.2 \\
14.0 \pm 0.2 \\
16.9 \pm 0.3 \\
1.9 \pm 0.2 \\
2.5 \pm 0.4\end{array}$ \\
\hline $\begin{array}{l}\text { R111 } \\
\text { R111 } \\
\text { R111 } \\
\text { R111 } \\
\text { R111 } \\
\text { R111 } \\
\text { R111 } \\
\text { R111 } \\
\text { R111 } \\
\text { R111 } \\
\text { R111 } \\
\text { R111 }\end{array}$ & $\begin{array}{l}\text { AM } \\
\text { AM } \\
\text { AM } \\
\text { AM } \\
\text { AM } \\
\text { AM } \\
\text { AM } \\
\text { AM } \\
\text { AM } \\
\text { AM } \\
\text { AM } \\
\text { AM }\end{array}$ & $\begin{array}{c}\text { Alanine } \\
\text { Glycine } \\
\text { Threonine } \\
\text { Serine } \\
\text { Valine } \\
\text { Leucine } \\
\text { Isoleucine } \\
\text { Proline } \\
\text { Aspartic } \\
\text { Glutamic acid } \\
\text { Phenylalanine } \\
\text { Lysine }\end{array}$ & $\begin{array}{l}3 \\
3 \\
3 \\
3 \\
3 \\
3 \\
3 \\
3 \\
3 \\
3 \\
3 \\
3 \\
\end{array}$ & $\begin{array}{c}18.6 \pm 0.3 \\
5.2 \pm 0.1 \\
-28.0 \pm 0.1 \\
5.7 \pm 0.3 \\
19.7 \pm 0.3 \\
18.2 \pm 0.3 \\
18.4 \pm 0.7 \\
16.4 \pm 0.9 \\
13.6 \pm 0.2 \\
17.6 \pm 0.3 \\
1.9 \pm 0.1 \\
3.4 \pm 0.2 \\
\end{array}$ \\
\hline $\begin{array}{l}\text { R112 } \\
\text { R112 } \\
\text { R112 } \\
\text { R112 } \\
\text { R112 } \\
\text { R112 } \\
\text { R112 } \\
\text { R112 } \\
\text { R112 } \\
\text { R112 } \\
\text { R112 } \\
\text { R112 }\end{array}$ & $\begin{array}{l}\text { AM } \\
\text { AM } \\
\text { AM } \\
\text { AM } \\
\text { AM } \\
\text { AM } \\
\text { AM } \\
\text { AM } \\
\text { AM } \\
\text { AM } \\
\text { AM } \\
\text { AM }\end{array}$ & $\begin{array}{c}\text { Alanine } \\
\text { Glycine } \\
\text { Threonine } \\
\text { Serine } \\
\text { Valine } \\
\text { Leucine } \\
\text { Isoleucine } \\
\text { Proline } \\
\text { Aspartic } \\
\text { Glutamic acid } \\
\text { Phenylalanine } \\
\text { Lysine }\end{array}$ & $\begin{array}{l}3 \\
3 \\
3 \\
3 \\
3 \\
3 \\
2 \\
3 \\
3 \\
3 \\
3 \\
3\end{array}$ & $\begin{array}{c}19.2 \pm 0.5 \\
4.8 \pm 0.5 \\
-28.0 \pm 0.7 \\
4.7 \pm 0.4 \\
19.7 \pm 0.1 \\
18.2 \pm 0.1 \\
17.7 \pm 0.6 \\
17.1 \pm 0.6 \\
14.3 \pm 0.4 \\
17.6 \pm 0.5 \\
3.9 \pm 0.2 \\
3.1 \pm 0.4\end{array}$ \\
\hline $\begin{array}{l}\text { R114 } \\
\text { R114 } \\
\text { R114 } \\
\text { R114 } \\
\text { R114 } \\
\text { R114 } \\
\text { R114 } \\
\text { R114 } \\
\text { R114 } \\
\text { R114 } \\
\text { R114 } \\
\text { R114 }\end{array}$ & $\begin{array}{l}\text { RS } \\
\mathrm{RS} \\
\mathrm{RS} \\
\mathrm{RS} \\
\mathrm{RS} \\
\mathrm{RS} \\
\mathrm{RS} \\
\mathrm{RS} \\
\mathrm{RS} \\
\mathrm{RS} \\
\mathrm{RS} \\
\mathrm{RS}\end{array}$ & $\begin{array}{c}\text { Alanine } \\
\text { Glycine } \\
\text { Threonine } \\
\text { Serine } \\
\text { Valine } \\
\text { Leucine } \\
\text { Isoleucine } \\
\text { Proline } \\
\text { Aspartic } \\
\text { Glutamic acid } \\
\text { Phenylalanine } \\
\text { Lysine }\end{array}$ & $\begin{array}{c}3 \\
3 \\
3 \\
3 \\
3 \\
3 \\
\text { na } \\
3 \\
3 \\
3 \\
3 \\
2\end{array}$ & $\begin{array}{c}17.6 \pm 0.4 \\
5.9 \pm 0.3 \\
-25.9 \pm 0.2 \\
5.9 \pm 0.8 \\
19.0 \pm 0.4 \\
17.5 \pm 0.4 \\
\mathrm{Na} \\
18.1 \pm 0.8 \\
12.9 \pm 0.2 \\
17.5 \pm 0.8 \\
3.1 \pm 0.3 \\
3.3 \pm 0.1\end{array}$ \\
\hline
\end{tabular}




\section{Antarctic Seal Foraging Ecology}

224 Table S9. Results of one-way ANOVA Bonferroni post-hoc comparisons for 225 amino acid $\delta^{15} \mathrm{~N}$ data for the three seal species. Significant $p$-values are $<0.05$.

\begin{tabular}{|c|c|c|}
\hline Amino Acid & $\begin{array}{c}\text { ANOVA Post-hoc } p \text { - } \\
\text { values }\end{array}$ & Comparison \\
\hline \multirow[t]{3}{*}{ Ala } & $<0.001$ & Crabeater vs. Ross \\
\hline & $<0.001$ & Crabeater vs. Weddell \\
\hline & 0.003 & Ross vs. Weddell \\
\hline \multirow[t]{3}{*}{ Gly } & - & Crabeater vs. Ross \\
\hline & - & Crabeater vs. Weddell \\
\hline & - & Ross vs. Weddell \\
\hline \multirow[t]{3}{*}{ Thr } & 0.01 & Crabeater vs. Ross \\
\hline & 0.006 & Crabeater vs. Weddell \\
\hline & - & Ross vs. Weddell \\
\hline \multirow[t]{3}{*}{ Ser } & - & Crabeater vs. Ross \\
\hline & $<0.001$ & Crabeater vs. Weddell \\
\hline & 0.002 & Ross vs. Weddell \\
\hline \multirow[t]{3}{*}{ Val } & $<0.001$ & Crabeater vs. Ross \\
\hline & $<0.001$ & Crabeater vs. Weddell \\
\hline & $<0.001$ & Ross vs. Weddell \\
\hline \multirow[t]{3}{*}{ Leu } & $<0.001$ & Crabeater vs. Ross \\
\hline & $<0.001$ & Crabeater vs. Weddell \\
\hline & $<0.001$ & Ross vs. Weddell \\
\hline \multirow[t]{3}{*}{ Ile } & $<0.001$ & Crabeater vs. Ross \\
\hline & $<0.001$ & Crabeater vs. Weddell \\
\hline & $<0.001$ & Ross vs. Weddell \\
\hline \multirow[t]{3}{*}{ Pro } & 0.03 & Crabeater vs. Ross \\
\hline & $<0.001$ & Crabeater vs. Weddell \\
\hline & $<0.001$ & Ross vs. Weddell \\
\hline \multirow[t]{3}{*}{ Asp } & $<0.001$ & Crabeater vs. Ross \\
\hline & $<0.001$ & Crabeater vs. Weddell \\
\hline & - & Ross vs. Weddell \\
\hline \multirow[t]{3}{*}{ Glu } & $<0.001$ & Crabeater vs. Ross \\
\hline & $<0.001$ & Crabeater vs. Weddell \\
\hline & $<0.001$ & Ross vs. Weddell \\
\hline \multirow[t]{3}{*}{ Phe } & $<0.001$ & Crabeater vs. Ross \\
\hline & - & Crabeater vs. Weddell \\
\hline & $<0.001$ & Ross vs. Weddell \\
\hline \multirow[t]{3}{*}{ Lys } & 0.009 & Crabeater vs. Ross \\
\hline & - & Crabeater vs. Weddell \\
\hline & 0.005 & Ross vs. Weddell \\
\hline
\end{tabular}




\section{Antarctic Seal Foraging Ecology}

228 Table S10. Bulk $\delta^{13} \mathrm{C}$ and $\delta^{15} \mathrm{~N}$ values of crabeater, Weddell, and Ross seals from the literature. Note,

229 bulk $\delta^{13} \mathrm{C}$ and $\delta^{15} \mathrm{~N}$ values are reported for the original measurement (Orig.) and with a correction to

230 whole blood (Corr.) if the sample is a tissue type with a significant isotopic offset from whole blood.

231 Isotopic offset between whole blood and the given sample type are reported in Tables S4 and S6, above.

232 Abbreviations: RBCs, red blood cells; F, female; M, male; na, information not available; NDR, no dive

233 records; RS, Ross Sea; AS, Amundsen Sea; WAP, West Antarctic Peninsula; $n$, sample size.

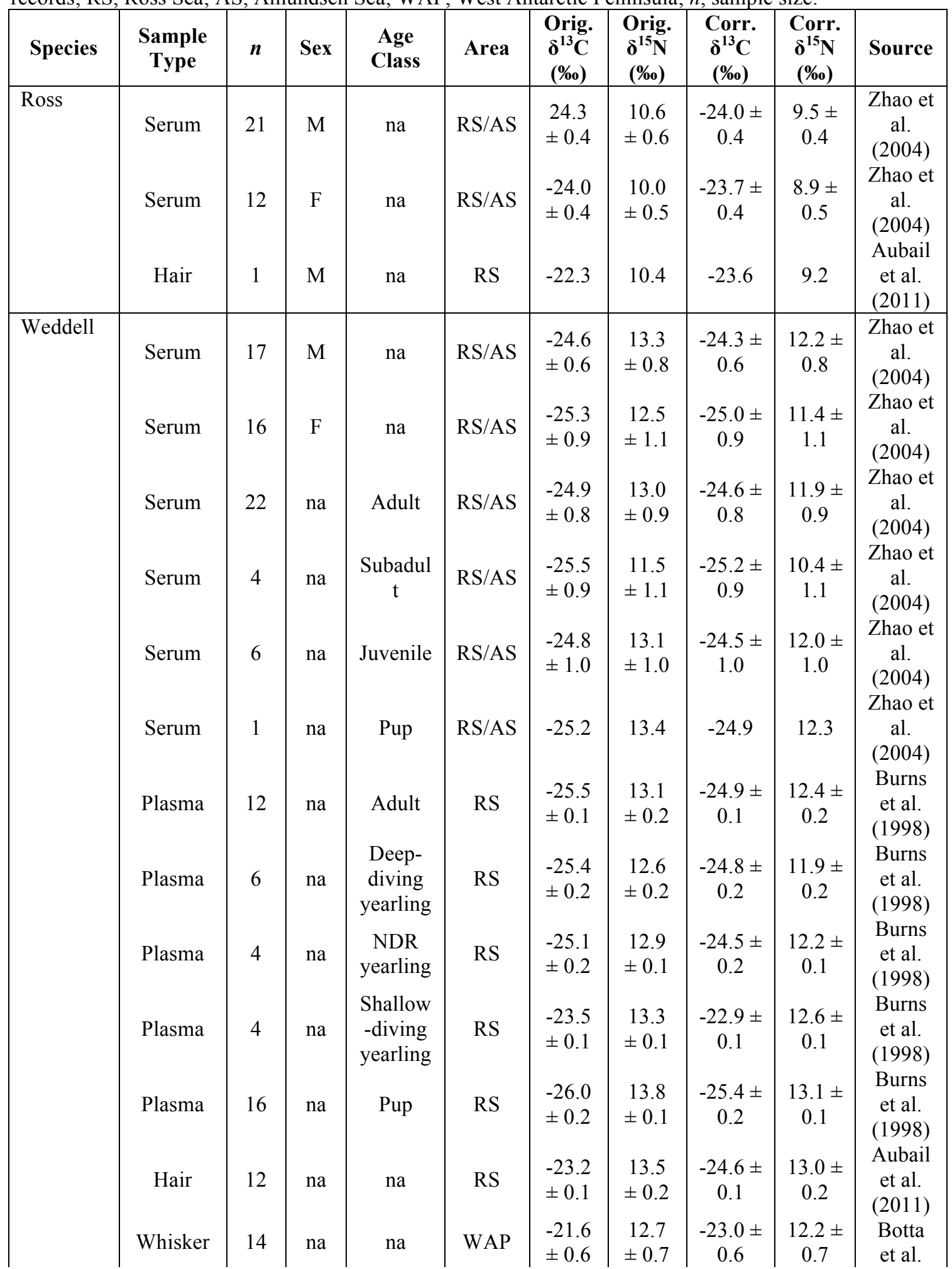


Antarctic Seal Foraging Ecology

\begin{tabular}{|c|c|c|c|c|c|c|c|c|c|c|}
\hline & RBCs & 116 & na & na & RS & $\begin{array}{l}-25.2 \\
\pm 0.3\end{array}$ & $\begin{array}{c}12.0 \pm \\
0.3\end{array}$ & $\begin{array}{c}-25.2 \pm \\
0.3\end{array}$ & $\begin{array}{c}12.3 \pm \\
0.3\end{array}$ & $\begin{array}{c}(2018) \\
\text { Goetz } \\
\text { et al. } \\
(2017)\end{array}$ \\
\hline \multirow[t]{8}{*}{ Crabeater } & Serum & 26 & $\mathrm{M}$ & na & $\mathrm{RS} / \mathrm{AS}$ & $\begin{array}{l}-26.7 \\
\pm 0.9\end{array}$ & $\begin{array}{c}8.2 \pm \\
0.5\end{array}$ & $\begin{array}{c}-26.4 \pm \\
0.9\end{array}$ & $\begin{array}{c}7.1 \pm \\
0.5\end{array}$ & $\begin{array}{c}\text { Zhao et } \\
\text { al. } \\
\text { (2004) }\end{array}$ \\
\hline & Serum & 15 & F & na & $\mathrm{RS} / \mathrm{AS}$ & $\begin{array}{l}-26.5 \\
\pm 1.2\end{array}$ & $\begin{array}{c}8.4 \pm \\
0.4\end{array}$ & $\begin{array}{c}-26.2 \pm \\
1.2\end{array}$ & $\begin{array}{c}7.3 \pm \\
0.4\end{array}$ & $\begin{array}{l}\text { Zhao et } \\
\text { al. } \\
\text { (2004) }\end{array}$ \\
\hline & Serum & 30 & na & Adult & $\mathrm{RS} / \mathrm{AS}$ & $\begin{array}{l}-26.5 \\
\pm 1.0\end{array}$ & $\begin{array}{c}8.4 \pm \\
0.6\end{array}$ & $\begin{array}{c}-26.2 \pm \\
1.0\end{array}$ & $\begin{array}{c}7.3 \pm \\
0.6\end{array}$ & $\begin{array}{l}\text { Zhao et } \\
\text { al. } \\
\text { (2004) }\end{array}$ \\
\hline & Serum & 4 & na & $\underset{t}{\text { Subadul }}$ & $\mathrm{RS} / \mathrm{AS}$ & $\begin{array}{l}-26.1 \\
\pm 1.2\end{array}$ & $\begin{array}{c}8.4 \pm \\
0.3\end{array}$ & $\begin{array}{c}-25.8 \pm \\
1.2\end{array}$ & $\begin{array}{c}7.3 \pm \\
0.3\end{array}$ & $\begin{array}{l}\text { Zhao et } \\
\text { al. } \\
\text { (2004) }\end{array}$ \\
\hline & Serum & 3 & na & Juvenile & $\mathrm{RS} / \mathrm{AS}$ & $\begin{array}{l}-27.2 \\
\pm 1.2\end{array}$ & $\begin{array}{c}8.0 \pm \\
0.1\end{array}$ & $\begin{array}{c}-26.9 \pm \\
1.2\end{array}$ & $\begin{array}{c}7.9 \pm \\
0.1\end{array}$ & $\begin{array}{c}\text { Zhao et } \\
\text { al. } \\
\text { (2004) }\end{array}$ \\
\hline & Serum & 4 & na & Pup & $\mathrm{RS} / \mathrm{AS}$ & $\begin{array}{l}-27.4 \\
\pm 0.4\end{array}$ & $\begin{array}{c}7.7 \pm \\
0.1\end{array}$ & $\begin{array}{c}-27.1 \pm \\
0.4\end{array}$ & $\begin{array}{c}6.6 \pm \\
0.1\end{array}$ & $\begin{array}{l}\text { Zhao et } \\
\text { al. } \\
\text { (2004) }\end{array}$ \\
\hline & Hair & 33 & na & na & RS & $\begin{array}{l}-24.3 \\
\pm 0.1\end{array}$ & $\begin{array}{c}7.7 \pm \\
0.1\end{array}$ & $\begin{array}{c}-25.9 \pm \\
0.1\end{array}$ & $\begin{array}{c}7.7 \pm \\
0.1\end{array}$ & $\begin{array}{l}\text { Aubail } \\
\text { et al. } \\
\text { (2011) }\end{array}$ \\
\hline & Whisker & 13 & na & na & WAP & $\begin{array}{l}-23.0 \\
\pm 0.6\end{array}$ & $\begin{array}{c}7.0 \pm \\
0.8\end{array}$ & $\begin{array}{c}-24.6 \pm \\
0.6\end{array}$ & $\begin{array}{c}7.0 \pm \\
0.8\end{array}$ & $\begin{array}{c}\text { Botta } \\
\text { et al. } \\
(2018)\end{array}$ \\
\hline
\end{tabular}

234

235

236

237

238

239

240

241

242

243

244

245

246

247

248

249

250

251

252

253
REFERENCES

Aubail A, Teilmann J, Dietz R, Rigét F, Harkonen T, Karlsson O, Rosing-Asvid A, Caurant F (2011) Investigation of mercury concentrations in fur of phocid seals using stable isotopes as tracers of trophic levels and geographic regions. Polar Biol 34:1411-1420

Botta S, Secchi ER, Rogers TL, Prado JH, de Lima RC, Carlini P, Negrete J (2018) Isotopic niche overlap and partition among three Antarctic seals from the Western Antarctic Peninsula. Deep Sea Res II 149:240-924

Burns JM, Trumble SJ, Castellini MA, Testa JW (1998) The diet of Weddell seals in McMurdo Sound, Antarctica as determined from scat collections and stable isotope analysis. Polar Biol 19:272-282

Goetz KT, Burns JM, Hückstädt LA, Shero MR, Costa DP (2017) Temporal variation in isotopic composition and diet of Weddell seals in the western Ross Sea. Deep Sea Res II 140:36-44 
Antarctic Seal Foraging Ecology

254 Hückstädt LA, Burns JM, Koch PL, McDonald BI, Crocker DE, Costa DP (2012a) Diet of a 255 specialist in a changing environment: the crabeater seal along the western Antarctic Peninsula. Mar Ecol Prog Ser 455:287-301

Zhao L, Castellini MA, Mau TL, Trumble SJ (2004) Trophic interactions of Antarctic seals as determined by stable isotope signatures. Polar Biol 27:368-373 